Prepared in cooperation with the Army Environmental Command

\title{
Assessment of Contaminant Trends in Plumes and Wells and Monitoring Network Optimization at the Badger Army Ammunition Plant, Sauk County, Wisconsin
}

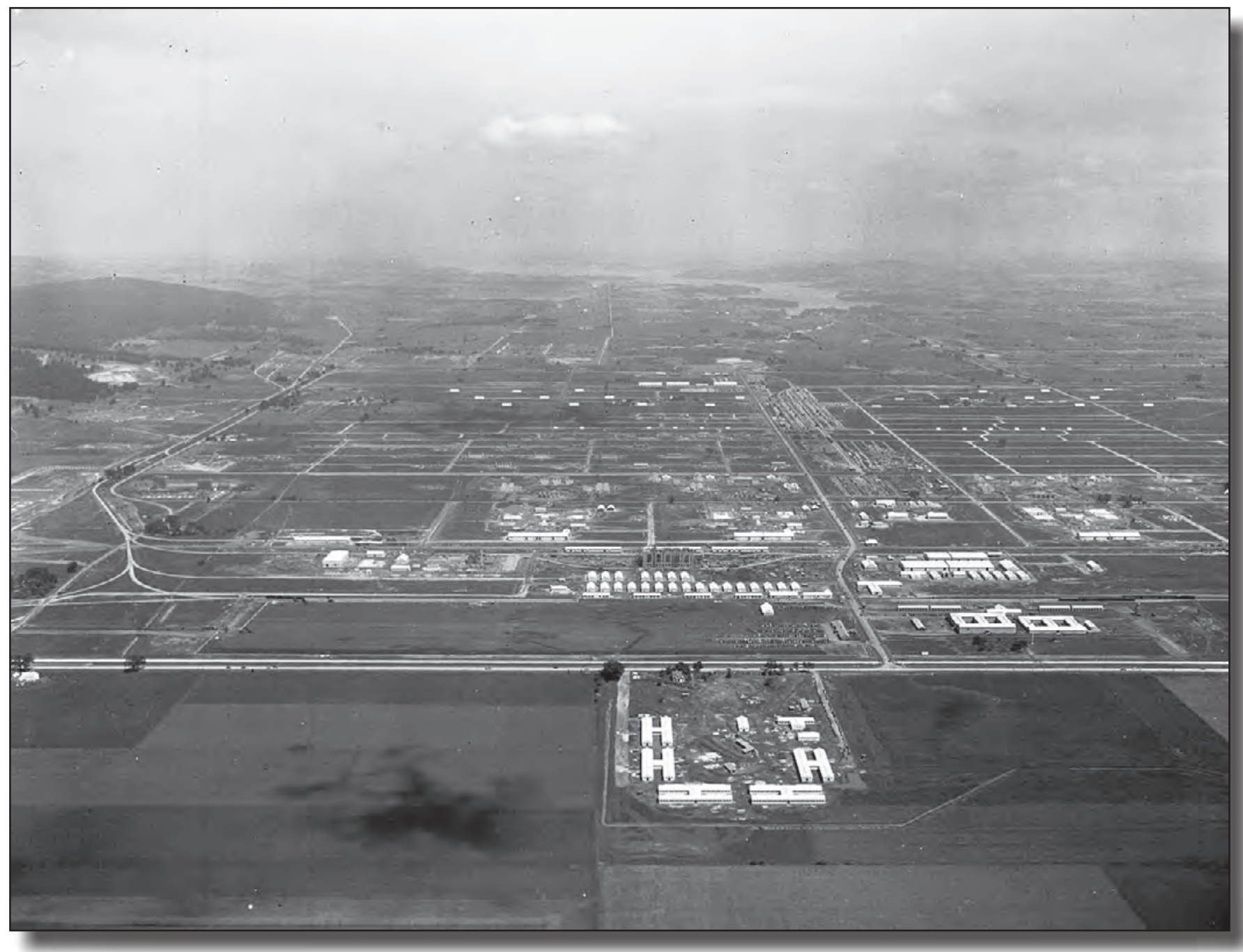

Scientific Investigations Report 2020-5106 
Cover. May 1942 aerial view looking east toward the north half of the Badger Army Ammunition Plant. Photograph number BHG.1999.0010.0211. Photograph provided by the Badger History Group, Inc., Museum of Badger Army Ammunition, used with permission. 


\section{Assessment of Contaminant Trends in Plumes and Wells and Monitoring Network Optimization at the Badger Army Ammunition Plant, Sauk County, Wisconsin}

By Matthew Pajerowski, Phillip Goodling, and Marina Metes

Prepared in cooperation with the Army Environmental Command

Scientific Investigations Report 2020-5106 


\section{U.S. Geological Survey, Reston, Virginia: 2021}

For more information on the USGS - the Federal source for science about the Earth, its natural and living resources, natural hazards, and the environment—visit https://www.usgs.gov or call 1-888-ASK-USGS.

For an overview of USGS information products, including maps, imagery, and publications, visit https://store.usgs.gov/.

Any use of trade, firm, or product names is for descriptive purposes only and does not imply endorsement by the U.S. Government.

Although this information product, for the most part, is in the public domain, it also may contain copyrighted materials as noted in the text. Permission to reproduce copyrighted items must be secured from the copyright owner.

Suggested citation:

Pajerowski, M., Goodling, P., and Metes, M., 2021, Assessment of contaminant trends in plumes and wells and monitoring network optimization at the Badger Army Ammunition Plant, Sauk County, Wisconsin: U.S. Geological Survey Scientific Investigations Report 2020-5106, 80 p., https://doi.org/10.3133/sir20205106.

Associated data for this publication:

Metes, M.J., Goodling, P.J., and Pajerowski, M.G., 2020, Groundwater quality and plume boundaries for select contaminants of concern at Badger Army Ammunition Plant, Wisconsin (2000-2018): U.S. Geological Survey data release, https://doi.org/10.5066/P97UKYNR.

ISSN 2328-0328 (online) 


\section{Acknowledgments}

The authors would like to acknowledge the U.S. Army Environmental Command for their support of this study and for providing the water-quality data used in analysis of the site environmental conditions. The authors also acknowledge Joel Janssen, SpecPro Professional Services, for providing additional datasets and giving technical guidance and background information about previous site investigations. 



\section{Contents}

Acknowledgments ……...................................................................................................................

Abstract

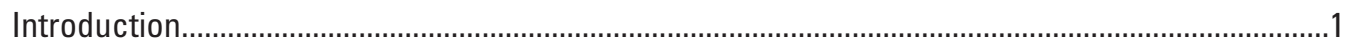

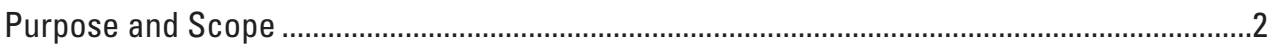

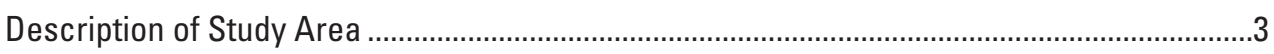

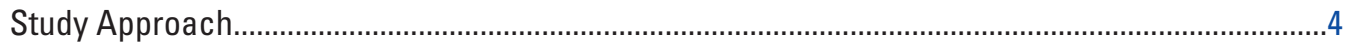

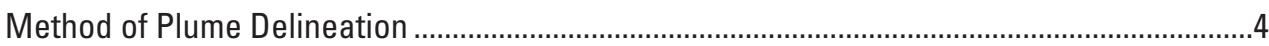

Aggregation of Data into Plume Analysis Periods ...........................................................

Procedures for Contaminant Concentrations Reported as Non-detect Values................6

Aggregation of Wells by Depth Intervals...............................................................

Wells Not Used in Plume Delineation Analysis ..................................................................

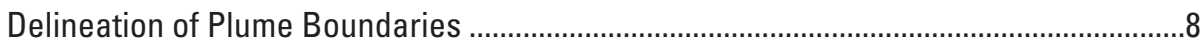

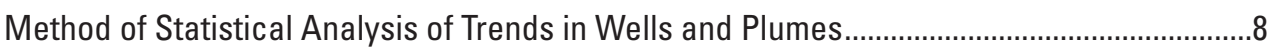

Data Input Parameters for Statistical Analysis ...........................................................

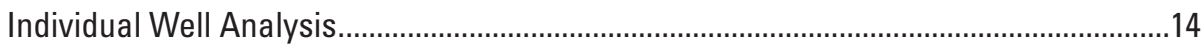

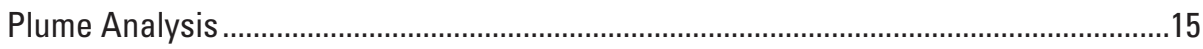

Monitoring Network Optimization .................................................................................15

Assessment of Contaminant Trends in Plumes and Wells............................................................

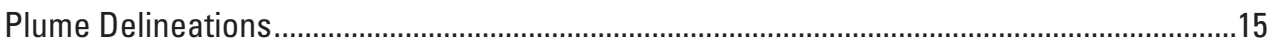

Propellant Burning Ground Plume ………….............................................................15

Central Plume ....................................................................................................16

Deterrent Burning Ground Plume ............................................................................18

Statistical Analysis of Contaminant Trends in Plumes and Individual Wells ...........................18

Propellant Burning Ground Plume .................................................................................36

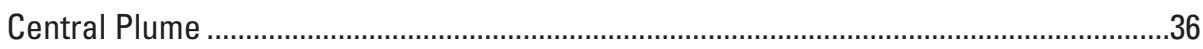

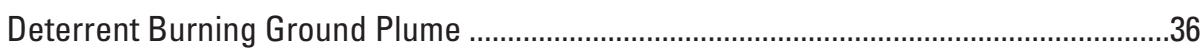

Individual Well Remediation Status ................................................................................

Comparison of Plume Boundary Delineations with Results of Statistical Analyses ...............49

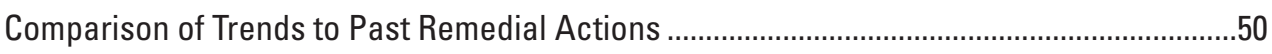

Monitoring Network Optimization .......................................................................................5

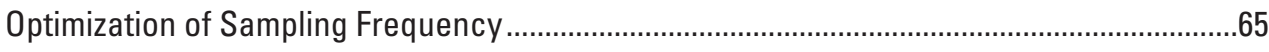

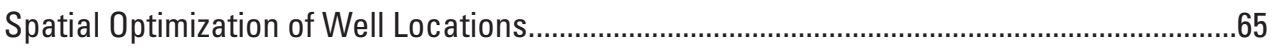

Effect of Network Well Removal on Plume Boundary Delineation...........................................65

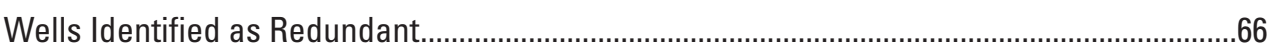

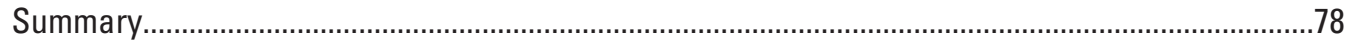

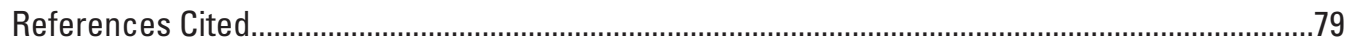

\section{Figures}

1. Map showing location of Badger Army Ammunition Plant study area,

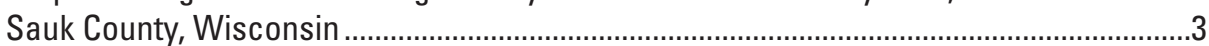

2. Diagram depicting the workflow for computation of plume boundaries ........................... 
3. Map showing Propellant Burning Ground plume boundaries for carbon tetrachloride, Badger Army Ammunition Plant, 2010-12

4. Cross-section $D-D^{\prime}$ along the mapped continuous gravel unit in the southern portion of the Propellant Burning Ground Plume, including well SWN-9103 B, Badger Army Ammunition Plant

5-11. Map showing-

5. Total dinitrotoluene plume delineations and concentration trends, Badger Army Ammunition Plant, for 2010-12 and 2013-18.

6. 2,4-dinitrotoluene plume delineations and concentration trends, Badger Army Ammunition Plant, for 2000-12 and 2013-18.

7. 2,6-dinitrotoluene plume delineations and concentration trends, Badger Army Ammunition Plant, for 2000-12 and 2013-18.

8. Trichloroethene plume delineations and concentration trends, Badger Army Ammunition Plant, for 2000-12 and 2013-18.

9. Carbon tetrachloride plume delineations and concentration trends, Badger Army Ammunition Plant, for 2000-12 and 2013-18.

10. 1,1,2-trichloroethane plume delineations and concentration trends, Badger Army Ammunition Plant, for 2000-12 and 2013-18..

11. Ethyl ether plume delineations and concentration trends, Badger Army Ammunition Plant, for 2004-12 and 2013-18.

12. Summary of well remediation status by Enforcement Standard for each contaminant of concern, Badger Army Ammunition Plant, 2000-12 and 2013-18

13-20. Map showing-

13. Status of total dinitrotoluene remediation in monitoring wells relative to the Enforcement Standard, Badger Army Ammunition Plant, for 2000-12 and 2013-18.

14. Status of 2,4-dinitrotoluene remediation in monitoring wells relative to the Enforcement Standard, Badger Army Ammunition Plant for 2000-12 and 2013-18

15. Status of 2,6-dinitrotoluene remediation in monitoring wells relative to the Enforcement Standard, Badger Army Ammunition Plant, for 2000-12, and 2013-18

16. Status of trichloroethene remediation in monitoring wells relative to the Enforcement Standard, Badger Army Ammunition Plant, for 2000-12 and 2013-18

17. Status of carbon tetrachloride remediation in monitoring wells relative to the Enforcement Standard, Badger Army Ammunition Plant, for 2000-12 and 2013-18

18. Status of 1,1,2-TCA remediation in monitoring wells relative to the Enforcement Standard, Badger Army Ammunition Plant study area, for 2000-12 and 2013-18

19. Status of ethyl ether remediation in monitoring wells relative to the Enforcement Standard, Badger Army Ammunition Plant, for 2000-12 and 2013-18

20. Location of wells that were identified as redundant and suggested to be considered for removal from the monitoring network. 


\section{Tables}

1. Contaminants of concern within the three major plumes at the Badger Army Ammunition Plant...

2. Summary of regulatory exceedances for contaminants of concern within three groundwater plumes, Badger Army Ammunition Plant

3. Number of wells for which the analysis period maximum concentration was derived from a non-detect analytical result that exceeds the Enforcement Standard or Preventive Action Limit, along with the total number of wells available for analysis for each time period, Badger Army Ammunition Plant...

4. The number of sampled wells used in analysis within each depth interval for each plume, Badger Army Ammunition Plant

5. Plume characteristics used as input data for spatial moment analyses of plumes, Badger Army Ammunition Plant.

6. One-half of median limit of detection for contaminant of concern for analysis periods 2000-2012 and 2013-2018, by plume

7. Criteria for assigning concentration trends and confidence based on Mann-Kendall Statistical results. Modified from Aziz and others, 2003

8. Results of trend analysis of total dinitrotoluene in the Propellant Burning Ground plume and in associated individual wells, Badger Army Ammunition Plant, 2010-12 and 2013-18.

9. Results of trend analysis of 2,4-dinitrotoluene in the Propellant Burning Ground plume and in associated individual wells, Badger Army Ammunition Plant, 2000-12 and 2013-18.

10. Results of trend analysis of 2,6-dinitrotoluene in the Propellant Burning Ground plume and in associated individual, Badger Army Ammunition Plant, 2000-12 and 2013-18.

11. Results of trend analysis of trichloroethene in the Propellant Burning Ground plume and in associated individual wells, Badger Army Ammunition Plant, 2000-12 and 2013-18

12. Results of trend analysis of carbon tetrachloride in the Propellant Burning Ground plume and in associated individual wells, Badger Army Ammunition Plant, 2000-12 and 2013-18

13. Results of trend analysis of ethyl ether in the Propellant Burning Ground plume and in associated individual wells, Badger Army Ammunition Plant, 2004-12 and 2013-18

14. Results of trend analysis of total dinitrotoluene in the Central plume and in associated individual wells, Badger Army Ammunition Plant, 2000-12 and 2013-18

15. Results of Trend analysis of 2,4-dinitrotoluene in the Central plume and in associated individual wells, Badger Army Ammunition Plant, 2000-12 and 2013-18

16. Results of trend analysis of 2,6-dinitrotoluene in the Central plume and in associated individual wells, Badger Army Ammunition Plant, 2000-12 and 2013-18

17. Results of trend analysis of total dinitrotoluene in the Deterrent Burning Ground plume and in associated individual wells, Badger Army Ammunition Plant, 2000-12 and 2013-18 
18. Results of trend analysis of 2,4-dinitrotoluene in the Deterrent Burning Ground plume and in associated individual wells, Badger Army Ammunition Plant, 2000-12 and 2013-18

19. Results of trend analysis of 2,6-dinitrotoluene in the Deterrent Burning Ground plume and in associated individual wells, Badger Army Ammunition Plant, 2000-12 and 2013-18

20. Results of trend analysis of trichloroethene in the Deterrent Burning Ground plume and in associated individual wells, Badger Army Ammunition Plant, 2000-12 and 2013-18

21. Results of trend analysis of 1,1,2-trichloroethane in the Deterrent Burning Ground plume and in associated individual wells, Badger Army Ammunition Plant, 2000-12 and 2013-18

22. Recommended sampling frequency using Monitoring and Remediation Optimization System.

23. Wells identified as providing redundant information for any contaminant of concern, Badger Army Ammunition Plant

24. Number of wells removed from the monitoring network between the 2010-12 and 2015-18 sampling periods, Badger Army Ammunition Plant 78

\section{Plates}

1-6. Map of Propellant Burning Ground plume delineations for-

1. Trichloroethene for the time periods $2000-02,2005-07,2010-12$, and 2015-18.

2. Carbon tetrachloride for the time periods $2000-02,2005-07,2010-12$, and 2015-18.

3. 2,4-dinitrotoluene for the time periods 2000-02, 2005-07, 2010-12, and 2015-18.

4. 2,6-dinitrotoluene for the time periods 2000-02, 2005-07, 2010-12, and 2015-18.

5. Total dinitrotoluene for the time periods $2000-02$, 2005-07, 2010-12, and 2015-18.

6. Ethyl ether for the time periods 2000-02, 2005-07, 2010-12, and 2015-18.

7-11. Map of Central plume delineations for-

7. Trichloroethene for the time periods $2000-02,2005-07,2010-12$, and 2015-18.

8. Carbon tetrachloride for the time periods $2000-02,2005-07,2010-12$, and 2015-18.

9. 2,4-dinitrotoluene for the time periods $2000-02,2005-07,2010-12$, and 2015-18.

10. 2,6-dinitrotoluene for the time periods 2000-02, 2005-07, 2010-12, and 2015-18.

11. Total dinitrotoluene for the time periods 2000-02, 2005-07, 2010-12, and 2015-18.

12-16. Map of Deterrent Burning Ground plume delineations for-

12. Trichloroethene for the time periods $2000-02,2005-07,2010-12$, and 2015-18.

13. 2,4-dinitrotoluene for the time periods $2000-02$, 2005-07, 2010-12, and 2015-18.

14. 2,6-dinitrotoluene for the time periods 2000-02, 2005-07, 2010-12, and 2015-18.

15. Total dinitrotoluene for the time periods $2000-02,2005-07,2010-12$, and 2015-18.

16. 1,1,2-trichloroethane for the time periods 2000-02, 2005-07, 2010-12, and 2015-18. 


\section{Conversion Factors}

U.S. customary units to International System of Units

\begin{tabular}{|c|c|c|}
\hline Multiply & By & To obtain \\
\hline \multicolumn{3}{|c|}{ Length } \\
\hline inch (in.) & 2.54 & centimeter $(\mathrm{cm})$ \\
\hline inch (in.) & 25.4 & millimeter (mm) \\
\hline foot $(\mathrm{ft})$ & 0.3048 & meter $(\mathrm{m})$ \\
\hline mile (mi) & 1.609 & kilometer $(\mathrm{km})$ \\
\hline \multicolumn{3}{|c|}{ Area } \\
\hline acre & 4,047 & square meter $\left(\mathrm{m}^{2}\right)$ \\
\hline acre & 0.4047 & hectare (ha) \\
\hline acre & 0.4047 & square hectometer $\left(\mathrm{hm}^{2}\right)$ \\
\hline acre & 0.004047 & square kilometer $\left(\mathrm{km}^{2}\right)$ \\
\hline square foot $\left(\mathrm{ft}^{2}\right)$ & 929.0 & square centimeter $\left(\mathrm{cm}^{2}\right)$ \\
\hline square foot $\left(\mathrm{ft}^{2}\right)$ & 0.09290 & square meter $\left(\mathrm{m}^{2}\right)$ \\
\hline square mile $\left(\mathrm{mi}^{2}\right)$ & 259.0 & hectare (ha) \\
\hline square mile $\left(\mathrm{mi}^{2}\right)$ & 2.590 & square kilometer $\left(\mathrm{km}^{2}\right)$ \\
\hline \multicolumn{3}{|c|}{ Volume } \\
\hline gallon (gal) & 3.785 & liter $(\mathrm{L})$ \\
\hline gallon (gal) & 0.003785 & cubic meter $\left(\mathrm{m}^{3}\right)$ \\
\hline cubic inch $\left(\mathrm{in}^{3}\right)$ & 0.01639 & liter $(\mathrm{L})$ \\
\hline \multicolumn{3}{|c|}{ Flow rate } \\
\hline acre-foot per day (acre-ft/d) & 0.01427 & cubic meter per second $\left(\mathrm{m}^{3} / \mathrm{s}\right)$ \\
\hline acre-foot per year (acre-ft/yr) & 1,233 & cubic meter per year $\left(\mathrm{m}^{3} / \mathrm{yr}\right)$ \\
\hline acre-foot per year (acre-ft/yr) & 0.001233 & cubic hectometer per year $\left(\mathrm{hm}^{3} / \mathrm{yr}\right)$ \\
\hline foot per second (ft/s) & 0.3048 & meter per second $(\mathrm{m} / \mathrm{s})$ \\
\hline foot per minute (ft/min) & 0.3048 & meter per minute $(\mathrm{m} / \mathrm{min})$ \\
\hline foot per hour (ft/h) & 0.3048 & meter per hour $(\mathrm{m} / \mathrm{h})$ \\
\hline foot per day (ft/d) & 0.3048 & meter per day $(\mathrm{m} / \mathrm{d})$ \\
\hline foot per year (ft/yr) & 0.3048 & meter per year (m/yr) \\
\hline gallon per day (gal/d) & 0.003785 & cubic meter per day $\left(\mathrm{m}^{3} / \mathrm{d}\right)$ \\
\hline
\end{tabular}

\section{Datum}

Vertical coordinate information is referenced to North American Vertical Datum of 1988 (NAVD 88).

Horizontal coordinate information is referenced to the North American Datum of 1983 (NAD 83).

Easting and Northing distances are referenced to StatePlane Wisconsin South FIPS 4803 Feet coordinate system.

Elevation, as used in this report, refers to distance above the vertical datum. 


\section{Supplemental Information}

Concentrations of chemical contaminants in water are given in either nanograms per liter (ng/L) or micrograms per liter $(\mu \mathrm{g} / \mathrm{L})$.

\section{Abbreviations}

$\begin{array}{ll}\text { 1,1,2-TCA } & \text { 1,1,2-trichloroethane } \\ \text { 2,4-DNT } & \text { 2,4-dinitrotoluene } \\ \text { 2,6-DNT } & \text { 2,6-dinitrotoluene } \\ \text { AEC } & \text { Army Environmental Command } \\ \text { BAAP } & \text { Badger Army Ammunition Plant } \\ \text { COC } & \text { Contaminant of concern } \\ \text { CTET } & \text { Carbon Tetrachloride } \\ \text { DBG } & \text { Deterrent Burning Ground } \\ \text { DNT } & \text { Dinitrotoluene } \\ \text { DOD } & \text { U.S. Department of Defense } \\ \text { EPA } & \text { U.S. Environmental Protection Agency } \\ \text { EE } & \text { Ethyl Ether } \\ \text { ES } & \text { Enforcement Standard } \\ \text { IRM } & \text { Interim Remedial Measure } \\ \text { LOD } & \text { Limit of Detection } \\ \text { MAROS } & \text { Monitoring and Remediation Optimization System } \\ \text { MIRM } & \text { Modified Interim Remedial Measure } \\ \text { MNA } & \text { Monitored Natural Attenuation } \\ \text { NA } & \text { Not Applicable } \\ \text { ND } & \text { non-detect } \\ \text { NR } & \text { Not reported } \\ \text { PAL } & \text { Preventive Action Limit } \\ \text { PBG } & \text { Propellant Burning Ground } \\ \text { PPm } & \text { part per million } \\ \text { TCA } & \text { Trichloroethane } \\ \text { TCE } & \text { Trichloroethene } \\ \text { TOC } & \text { Top of casing } \\ \text { USGS } & \text { U.S. Geological Survey } \\ & \\ \text { DA }\end{array}$




\title{
Assessment of Contaminant Trends in Plumes and Wells and Monitoring Network Optimization at the Badger Army Ammunition Plant, Sauk County, Wisconsin
}

\author{
By Matthew Pajerowski, Phillip Goodling, and Marina Metes
}

\section{Abstract}

Soil and groundwater at the Badger Army Ammunition Plant (BAAP), Sauk County, Wisconsin, were affected by several contaminants as a result of production and waste disposal practices common during its operation from 1942 to 1975 . Three distinct plumes of contaminated groundwater originate on BAAP property and extend off-site, as identified by previous studies. Routine sampling of groundwater quality from a network of monitoring wells and off-site private wells has been performed since 1990, although the number of wells monitored and the monitoring frequency have varied as the approved monitoring plan was modified. During the period of monitoring from 1990 to 2018, numerous site investigations and remedial actions were conducted to address the sources of contamination, contaminated soils, and groundwater. Concentrations of contaminants reportedly decreased between 2000 and 2012 within all three plumes. Five or six contaminants of concern (COCs) were identified for each of the three plumes. An independent assessment of the contaminant plumes and of the monitoring network was conducted using groundwater-quality data collected from more than 600 wells between 2000 and 2018 .

In a study conducted by the U.S. Geological Survey (USGS), in cooperation with the Army Environmental Command, a consistent data aggregation and interpolation scheme was applied to derive the likely maximum groundwater plume extents in four 3-year time periods between 2000 and 2018. The plume extent was defined by the Enforcement Standard for each COC and represents the maximum concentration observed in each 3-year time period. The plume boundary analysis shows that the spatial extent of groundwater contamination decreased for most COCs during the study period. Some plume boundaries are not well delineated by the existing monitoring network, particularly the downgradient edge of the Propellant Burning Ground plume. Maps identify the plume boundary in each time period, the sampling well network used to delineate the plume, and wells that were sampled in the 2010-12 period but not sampled in the 2015-18 period.

A series of statistical analyses using the Monitoring and Remediation Optimization System, version 3.0, program were applied to the available COC concentration data for two distinct periods, 2000 to 2012 and 2013 to 2018, with the break between periods coinciding with changes to the monitoring network in 2013. Trends in the concentration of COCs in individual wells varied, although generally more wells had decreasing than had increasing concentrations for most COCs in both time periods. The exceptions were ethyl ether in the 2004-12 period and 2,6-dinitrotoluene in the 2013-18 period, for which more wells had an increasing trend. Spatial moment analysis of concentration data from the well network was used to assess the stability of each plume for the COCs. During the 2000-12 period, most of the contaminant plumes for which data were sufficient to complete the analysis were either decreasing or stable in mass and size. The exceptions were carbon tetrachloride (associated solely with the Propellant Burning Ground plume) and 2,4-dinitrotoluene and 2,6-dinitrotoluene (in the Deterrent Burning Ground plume), which showed an increasing trend in mass. No COCs showed an increasing trend in plume mass in the 2013-18 period. Some wells with increasing trends in concentration or with concentrations greater than the enforcement standard are near the tail of a plume, where increased monitoring may be of value to better define future plume boundaries. A spatial optimization analysis covering the 2013-18 period identified six wells that provided information redundant to that from other wells. A temporal optimization analysis identified optimal sampling frequencies for 125 wells. Remedial actions directed at the Propellant Burning Ground plume coincided with a general decrease in plume mass and size, although in specific areas and depths, the plume size for specific contaminants may still be increasing.

\section{Introduction}

The Badger Army Ammunition Plant (BAAP) in Sauk County in south-central Wisconsin was constructed in 1942 to produce smokeless gunpowder and solid rocket propellant as munitions components for World War II (SpecPro, Inc. and Badger Technical Services, LLC, 2011). The plant operated intermittently until March 1975 when production ceased (U.S. Army, 1977). Soil and groundwater at the BAAP were 
affected by several contaminants as a result of production and waste disposal practices that were common during the period of operation.

Beginning in 1977, numerous site investigations and remedial actions were conducted at the BAAP. Remedial activities included removal of contaminated soils; removal of all chemicals, equipment, and structures associated with plant operations; removal of affected sewer infrastructure; and groundwater monitoring and remediation. In 1980, when groundwater monitoring and characterization began, groundwater was found to be contaminated. Past groundwater assessment activities included monitoring well installation, groundwater level measurement, water-quality sampling of monitoring and residential wells, aquifer testing, and groundwater modeling. During previous investigations (Warzyn Engineering, Inc, 1982; ABB Environmental Services, Inc., 1993a; ABB Environmental Services, Inc., 1993b; SpecPro, Inc. and Badger Technical Services, LLC, 2011), three distinct plumes of contaminated groundwater were identified, which originate on BAAP property and extend off-site. These three plumes are known as the Propellant Burning Ground (PBG) plume, Central Plume, and Deterrent Burning Ground (DBG) plume. Various remedial actions have been taken to address the sources of contamination, contaminated soils, and the groundwater contaminant plumes (SpecPro Inc. and Badger Technical Services, LLC, 2011). In 1990, an Interim Remedial Measure (IRM) was implemented, which involved removal and treatment of contaminated groundwater using extraction wells near the installation boundary. In 1996, the Modified Interim Remedial Measure (MIRM) was put into operation, increasing the number of wells and extraction rate of groundwater. The IRM and MIRM operated through 2012 and 2015 , respectively. Other remediation actions are discussed in more detail farther on in this report.

Routine sampling of groundwater quality from a network of monitoring wells and off-site private wells has been performed since 1990 (Badger Technical Services, 2013a). The number of wells sampled and the sampling frequency varied as modifications were made to the approved monitoring plan over the years (Badger Technical Services, 2013b). Concentrations of contaminants reportedly decreased between 2000 and 2012 within all three plumes. In 2013, the Army Environmental
Command (AEC) proposed a reduction in the number of private wells routinely sampled near BAAP (Badger Technical Services, 2013a).

The AEC has proposed Monitored Natural Attenuation (MNA) as one possible remedy for all three plumes. The AEC has identified the need for an independent assessment of the groundwater contaminant plumes and of the adequacy of the well network to monitor future changes in the contaminant plumes. The U.S. Geological Survey (USGS), in cooperation with the AEC, conducted a study to delineate contaminant plume boundaries and assess trends in contaminant concentrations. The information provided by this study can be used to inform future decisions on how to best adjust the well network and sampling frequency to meet monitoring goals.

\section{Purpose and Scope}

The purpose of this report is to (1) present delineations of the three major contaminant plumes at various time periods between 2000 and 2018 and (2) present the results of statistical analyses of concentration trends in individual wells and describe changes in plume mass and size over the same time period. The report relates the results of the plume delineations and analyses to the timing of certain source control actions. The report identifies changes that were made in the monitoring network that reduced the certainty of later plume delineations. Certain areas are identified where additional water-quality monitoring would reduce uncertainty associated with plume extent or plume trends, and certain wells are identified for which continued monitoring of specific contaminants would not add substantially to future assessments.

Five or six contaminants of concern (COCs) were selected for analysis for each of the three major plumes. (table 1) The COCs were selected in consultation with the AEC after a review of earlier reports of groundwater investigations at the site. Water-quality sample results from 687 wells on or near the BAAP were provided by the AEC in a Microsoft Access database. The data included sampling events from January 2000 through October 2018.

Table 1. Contaminants of concern within the three major plumes at the Badger Army Ammunition Plant.

$[\mathrm{X}$, indicates the contaminant is of concern relevant to the corresponding plume; - , indicates the contaminant is not of concern relevant to the corresponding plume]

\begin{tabular}{|c|c|c|c|c|}
\hline Contaminant of concern & $\begin{array}{l}\text { Acronym used in this } \\
\text { report }\end{array}$ & $\begin{array}{l}\text { Propellant Burning } \\
\text { Ground plume }\end{array}$ & Central plume & $\begin{array}{c}\text { Deterrent Burning Ground } \\
\text { plume }\end{array}$ \\
\hline Total dinitrotoluene & DNT & $\mathrm{X}$ & $\mathrm{X}$ & $\mathrm{X}$ \\
\hline 2,4-dinitrotoluene & 2,4-DNT & $\mathrm{X}$ & $\mathrm{X}$ & $\mathrm{X}$ \\
\hline 2,6-dinitrotoluene & 2,6-DNT & $\mathrm{X}$ & $\mathrm{X}$ & $\mathrm{X}$ \\
\hline Trichloroethene & TCE & $\mathrm{X}$ & $\mathrm{X}$ & $\mathrm{X}$ \\
\hline 1,1,2-trichloroethane & $1,1,2-\mathrm{TCA}$ & - & $\mathrm{X}$ & $\mathrm{X}$ \\
\hline Carbon tetrachloride & CTET & $\mathrm{X}$ & - & - \\
\hline Ethyl ether & $\mathrm{EE}$ & $\mathrm{X}$ & - & - \\
\hline
\end{tabular}




\section{Description of Study Area}

The BAAP study area is on the Sauk Prairie, between the Baraboo Range and the Wisconsin River, within Sumpter and Merrimac Townships. The BAAP occupies about 7,300 acres and is bordered by Devil's Lake State Park to the north, a mix of farmland and residential use to the south and east, the Wisconsin
River on the southeast, and a residential subdivision to the west (fig. 1). The study area extends to the east and south of the installation boundaries. The villages of Sauk City and Prairie du Sac are south of the BAAP.

The study area is underlain by glacial deposits, which affect the surface topography and the movement of groundwater in the subsurface. The topography is characterized by gently rolling

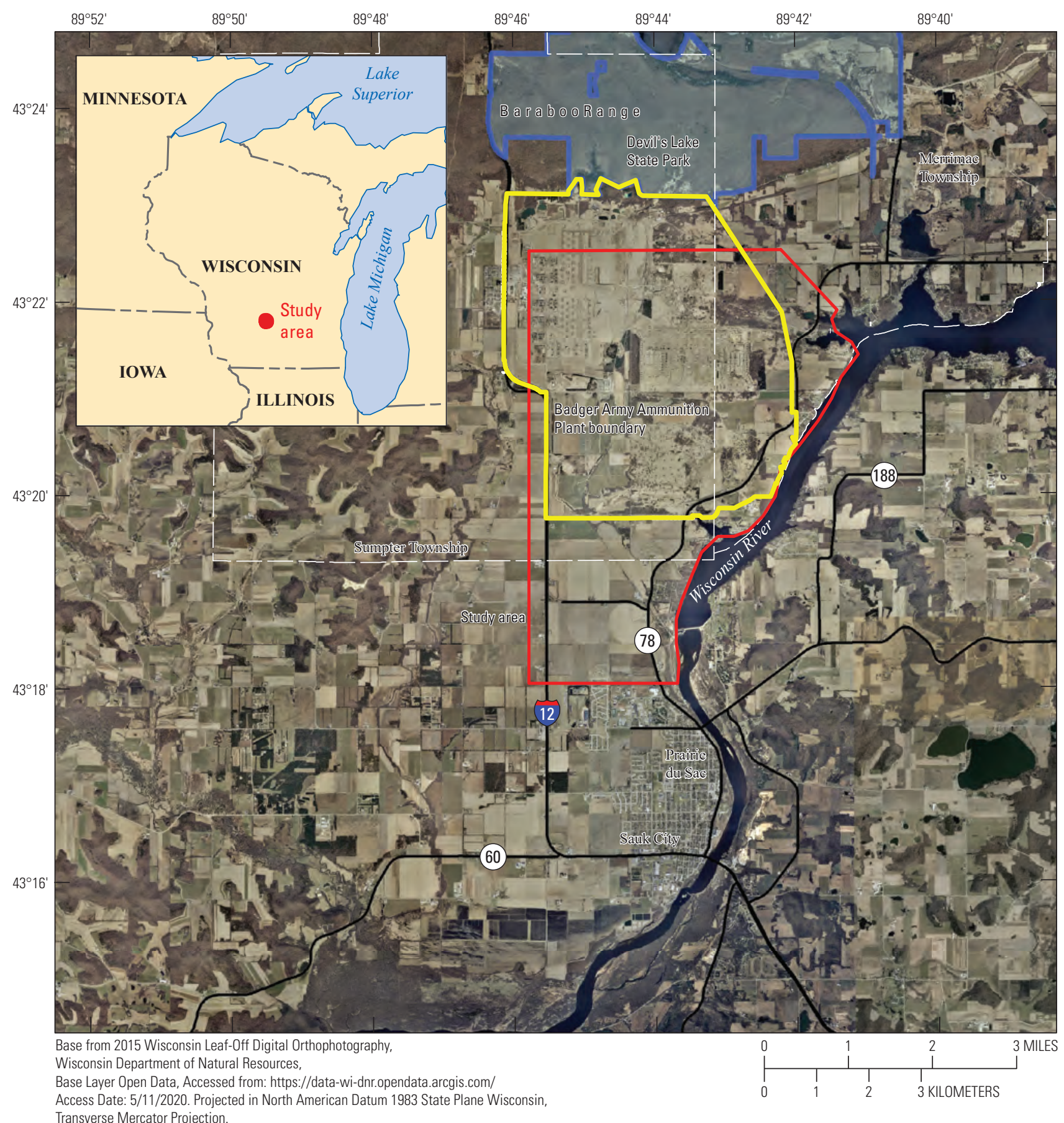

Figure 1. Location of Badger Army Ammunition Plant study area, Sauk County, Wisconsin. 
hills on the eastern two-thirds and a nearly level to gently sloping outwash plain on the western third of the BAAP (U.S Army, 1977). The average elevation of the study area is about 800 feet (ft) above the North American Vertical Datum of 1988. The eastern part of the study area drains to the east and south into the Wisconsin River, whereas the smaller northwestern part drains west into an unnamed tributary, which empties into the Wisconsin River. Glacial deposits at the study area include till and meltwater-stream sediments composed mostly of sand but with some gravelly sand, and some silt or clay (Attig and Clayton, 1990). The thickness of unconsolidated sediments ranges from less than $10 \mathrm{ft}$ at the northern boundary to $250 \mathrm{ft}$ at the southern boundary (SpecPro Inc. and Badger Technical Services, LLC, 2011). The unconsolidated glacial sediments are underlain by bedrock, mainly the Eau Claire Formation, which consists of sandstone, shale, siltstone, and dolomite, and some Precambrian metamorphosed quartzite, granite, and rhyolite.

\section{Study Approach}

The study consisted of a review of existing reports and data generated in the course of previous monitoring activities at the site, and a re-analysis of existing water-quality data. Reports that were reviewed in the course of the study include

- Master Environmental Plan for the Badger Army Ammunition Plant, Volume 1 (Tsai and others, 1988)

- Master Environmental Plan for the Badger Army Ammunition Plant, Volume 2 (Tsai and others, 1987)

- Phase I Draft Final Interim Remedial Investigation Report (E.C. Jordan Co., 1990a)

- Phase II Remedial Investigation Sampling Design Plan Addendum (E.C. Jordan Co., 1990b)

- Geological and Soil Survey and Groundwater Monitoring Program, Badger Army Ammunition Plant (Warzyn Engineering Inc., 1982)

- Alternative Feasibility Study Groundwater Remedial Strategy Badger Army Ammunition Plant (SpecPro, Inc. and Badger Technical Services, LLC, 2011)

- Private Well Sampling Reduction Plan Badger Army Ammunition Plant (Badger Technical Services, 2013a)

- 2013 Groundwater Narrative Summary Report Badger Army Ammunition Plant (Badger Technical Services, 2013b)

- 2014 Monitoring Well Optimization Plan, Deterrent Burning Ground and Central plumes (Badger Technical Services, 2014a)

- 2014 Groundwater Narrative Summary Report (Badger Technical Services, 2014b)
- 2015 Groundwater Narrative Summary Report (Badger Technical Services, 2015)

- Conditions of Approval DBG Remedy Update Report (U.S. Army Corps of Engineers, 2013)

- Surface Waters Impact Investigation Badger Army Ammunition Plant (Badger Technical Services, 2013c).

Two lines of analysis were applied to available waterquality data: plume delineation and statistical analysis of concentration trends in wells and in plumes. The water-quality data were furnished by the AEC in a Microsoft Access database that included the analytical results of groundwater samples from more than 600 wells, collected from January 2000 through October 2018 (Metes and others, 2020). Contaminant plumes were delineated for as many as six COCs for each of the three major plumes. The plumes were delineated for four distinct periods from 2000 through 2018 to identify changes over time. Statistical analyses of the water-quality data were performed independently of the plume delineation. The data were analyzed to identify contaminant trends over time in individual wells and to identify changes in mass, size, or location of each of the three plumes. Optimization software was used to analyze the adequacy of the monitoring network as it existed in 2012 and in 2018. The results of the plume delineations and the statistical analyses were compared to each other and to the timing of known remedial activities and changes to the monitoring network.

\section{Method of Plume Delineation}

A geostatistical approach to plume boundary delineation provides a consistent, reproducible process for identifying the spatial extent of a groundwater plume. In this study, naturalneighbor interpolation (Sibson, 1981) was applied to COC concentrations at wells at various depth intervals. The naturalneighbor technique uses an area-weighting method to interpolate a value at a new location. The interpolation technique is deterministic and is appropriate for irregularly distributed data about which the spatial distribution is not well known. It does not infer trends or an underlying distribution to the data, nor does it produce local minima or maxima beyond the range of the input data. It is a global interpolation technique, so to avoid extrapolating from physically unreasonable distances, the interpolation was separately applied to monitoring wells around each of the three groundwater plumes. Locations where plume boundaries are uncertain or poorly defined by the groundwater data were then qualitatively identified and designated using dashed lines. Dashed lines indicate locations where the plume boundary cannot be reliably interpolated owing to limitations in the spatial distribution of sampled wells.

For the purposes of this analysis, the plume boundaries are defined by the COC-specific Enforcement Standard (ES) and Preventive Action Limit (PAL) concentrations shown in table 2, which are described in the Wisconsin Administrative Code NR 140.10 (Wisconsin Legislative Reference Bureau, 
2020). PALs are always lower than ES limits, and although they are "not intended to always require remedial action..." (Natural Resources 140.02) indicate that activities affecting groundwater must "maintain compliance with the Preventive Action Limits unless compliance with the Preventive Action Limits is not technically and economically feasible" (NR 140.02). A regulatory standard for total dinitrotoluene (DNT) was established in the Wisconsin Code NR 140.10 on January 1, 2011, by CR 09-102 (Wisconsin Department of Natural Resources, 2010). Laboratory results for total DNT were not reported before this time. Delineation of the PAL concentrations was not possible for DNT contaminants because laboratory detection limits for these contaminants often exceeded the PAL. During time periods when no COC exceeded the ES or PAL, no plume boundary could be drawn. Table 2 indicates, for selected COCs, time periods when the ES or PAL was exceeded. Because of the conservative interpolation technique applied here and the method of data aggregation described below, the results of this analysis provide the likely maximum extent of area where concentrations exceed the groundwater ES at any depth.

Table 2. Summary of regulatory exceedances for contaminants of concern within three groundwater plumes, Badger Army Ammunition Plant.

[DNT, dinitrotoluene; TCA, trichloroethane; TCE, trichloroethene; CTET, carbon tetrachloride; PAL, Preventive Action Limit; ES, Enforcement Standard; NR, no results; $\mu \mathrm{g} / \mathrm{L}$, microgram per liter. Red boxes with an "ES" designate time periods when an Enforcement Standard exceedance is observed in a given plume. Grey boxes with an "NR" designate time periods when the laboratory did not report the contaminant. Yellow boxes with a "PAL" designate time periods when the Preventive Action Limit was exceeded but the Enforcement Standard was not exceeded. Green cells with "—-" designate time periods when no exceedances were observed, and no plume map was drawn]

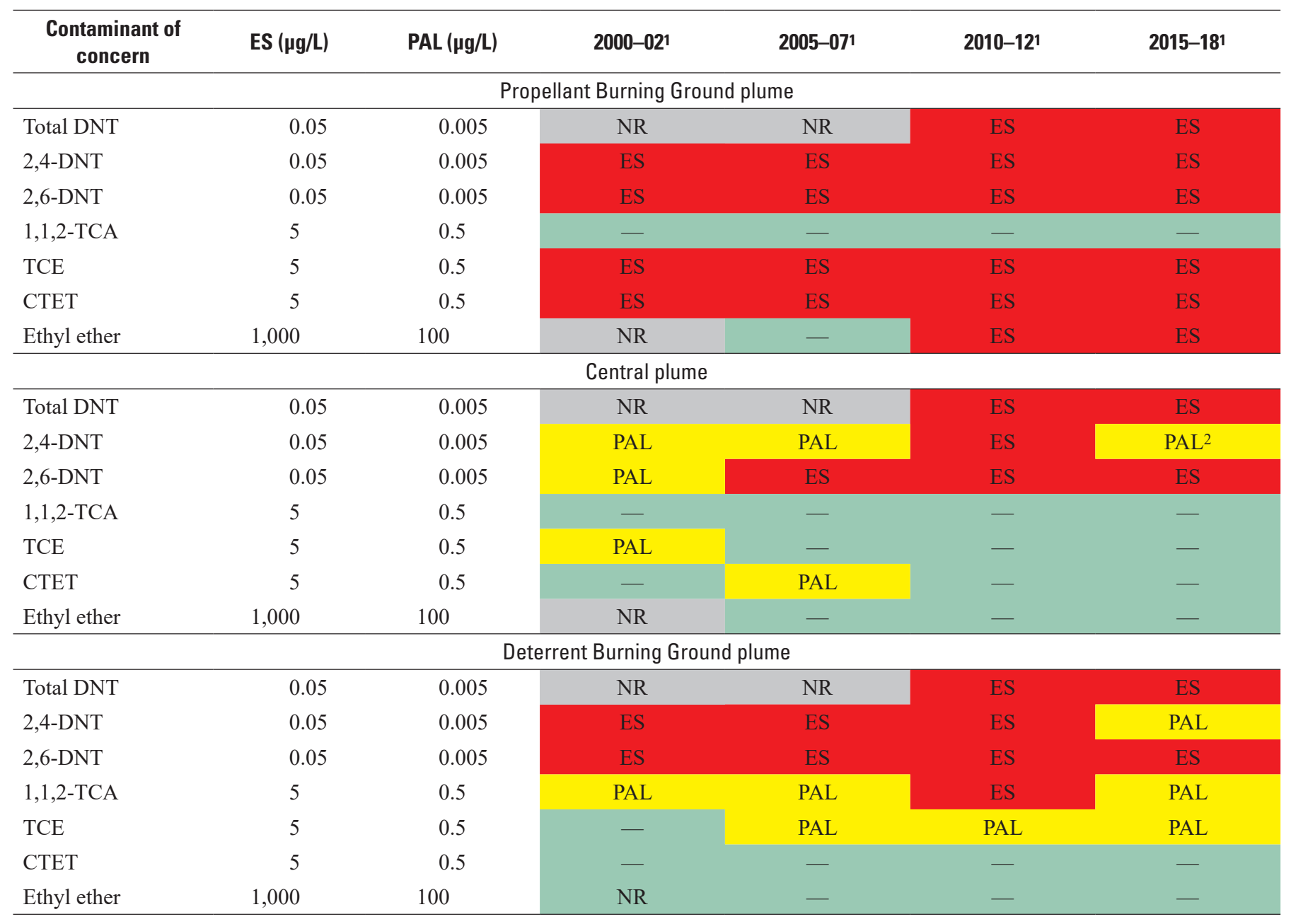

${ }^{1}$ All periods are 3-year periods. Except for 2015-18, the periods are January 1 of the first year through December 31 of the later year. The $2015-18$ period is November 1, 2015, to October 31, 2018. Plume lines were not drawn for DNT contaminants to the PAL level, since the PAL was below detection limits for many samples.

2One-half the limit of detection exceeds ES in some cases. 


\section{Aggregation of Data into Plume Analysis Periods}

All groundwater sampling results from January 2000 through October 2018 were compiled for each of the seven COCs identified in table 1 . These analytical results were previously reported in groundwater monitoring reports prepared by BAAP contractors and were made available to the USGS in a database. The analytical results were grouped by well using the well license number concatenated with the AECassigned unique well identification number. Not all wells were sampled at the same frequency; wells may have been sampled quarterly, semi-annually, annually, or biennially. In order to look at changes to the plumes over time, while also limiting the effect of the well network variability on the resulting plume boundary delineations, the data were aggregated into 3 -year periods. This 3 -year aggregation increases the number of wells available for spatial analysis, though it decreases the temporal resolution of each plume boundary. For each of the analysis periods $(2000-02,2005-07,2010-12,2015-18)$ the delineations represent the maximum area where concentrations exceed the groundwater ES or PAL.

\section{Procedures for Contaminant Concentrations Reported as Non-detect Values}

To perform numerical interpolation, a decision is needed on how to treat samples in which no COC was detected but that may contain contaminants at concentrations less than the limit of detection (LOD). In this analysis, non-detect (ND) values were assigned a value of one-half the detection limit, a commonly applied approach in risk assessment to handling left-censored data (Smith, 1991). The approach assumes that on average all values between the detection limit and zero could be present (Smith, 1991). Limits of detection are matrix-, method-, and analyte-specific, so the detection limit is variable within and among sampling events. When the limit of detection exceeds the ES, plume delineation becomes problematic. To limit the influence of ND sample results analyzed with a high limit of detection within a single 3-year period, reported ND values were handled in the following manner.

1. If a well had more than one sample detection in a year, the maximum reported concentration was used as the yearly value.

2. If the only results in a year for a well were NDs (qualified by the laboratory with a "ND" flag), then the minimum of all $\frac{\text { detection limit }}{2}$ values was used as the yearly value. This step limits the influence of a few samples with very high detection limits.

3. The maximum of the three yearly values (for example, 2000-02) was used as the 3-year-period value.

The rationale for this approach is that a verified analytical result above the detection limit gives more information than a left-censored ND value, even if the limit of detection is high. Under this procedure, the only wells assigned a 3-year period concentration value that is one-half of a detection limit did not have a single detection. Despite this handling, the detection limit exceeds the ES for some samples, particularly for DNT COCs during the 2000-02 and 2005-07 sampling periods and in the upgradient parts of the Central plume. Table 3 shows the number of wells for which the 3-year value used for interpolation was derived from a ND value greater than the ES.

\section{Aggregation of Wells by Depth Intervals}

A procedure was developed to ensure that concentrations were compared among wells of similar depths. The motivation for this work is to define the horizontal extent of groundwater contamination. However, the groundwater-monitoring wells installed at BAAP span a range of depths. Each groundwater contaminant plume has a three-dimensional extent. To make

Table 3. Number of wells for which the analysis period maximum concentration was derived from a non-detect analytical result that exceeds the Enforcement Standard or Preventive Action Limit, along with the total number of wells available for analysis for each time period, Badger Army Ammunition Plant.

[DNT, dinitrotoluene; N/A, sample results not available because there was no regulatory standard]

\begin{tabular}{|c|c|c|c|c|c|c|c|c|}
\hline \multirow[t]{2}{*}{ Contaminant of concern } & \multicolumn{4}{|c|}{$\begin{array}{c}\text { Number of wells for which the maximum analysis } \\
\text { period concentration value is derived from a } \\
\text { non-detect analytical result that exceeds the } \\
\text { Enforcement Standard }\end{array}$} & \multicolumn{4}{|c|}{$\begin{array}{l}\text { Number of wells for which the maximum analysis } \\
\text { period concentration value is derived from a non-detect } \\
\text { analytical result that exceeds the Preventative Action } \\
\text { Limit }\end{array}$} \\
\hline & $2000-02$ & $2005-07$ & 2010-12 & $2015-18$ & $2000-02$ & $2005-07$ & 2010-12 & 2015-18 \\
\hline 2,4-DNT & 10 of 206 & 0 of 282 & 0 of 291 & 10 of 292 & 92 of 206 & 54 of 282 & 237 of 291 & 10 of 292 \\
\hline 2,6-DNT & 9 of 206 & 0 of 282 & 0 of 292 & 10 of 292 & 62 of 206 & 78 of 282 & 201 of 291 & 267 of 292 \\
\hline
\end{tabular}


the two-dimensional horizontal plume delineations physically meaningful, interpolations between groundwater contaminant concentrations were completed with data from wells with similar depths. These interpolations provide representations of concentrations through horizontal slices of the plume body. The outer extent of the plume body in each of these slices, when projected onto the ground surface, provides the map-view plume extent. Wells for which the depth is unknown (mostly residential wells) were excluded from the analysis because interpreting the results without knowing the depth of the wells could lead to mischaracterization of the plume extent.

The geological conceptual site model previously developed at BAAP consists of three hydrogeologic units. The surficial aquifer lies within glacial till and glacial outwash deposits of interlayered sand and gravel units that extend to a depth of 80-280 ft below ground surface (SpecPro Professional Services, 2018). Below the unconsolidated sand and gravel aquifer lies the Eau Claire Formation, which consists of sandstone, dolomite, siltstone, and shale. The top of this formation is hydraulically connected with the overlying unconsolidated aquifer. Beneath the eastern part of BAAP, downgradient from the PBG area, the Eau Claire Formation is thought to contain a continuous shale layer that acts as a confining unit, creating a deeper confined aquifer (SpecPro Professional Services, 2018).

Many monitoring wells at BAAP had been assigned a letter designation $\mathrm{A}$ through $\mathrm{F}$ during previous investigations, corresponding to their relative completion depths (that is, the depth of their screen openings). Many of the groundwater monitoring wells at BAAP are in nested well groups. These wells have an AEC-established alphabetical naming system with the shallowest well designated " $\mathrm{A}$ " and the deepest well designated "F." Generally, "A" wells are screened near the water table in the unconsolidated sand and gravel aquifer, "B" wells are completed one-third of the depth from the water table to the bedrock, "C" wells are completed two-thirds of the depth from the water table to the bedrock, "D" wells are completed just above the bedrock, "E" wells are completed in the Eau Claire Formation bedrock, and "F" wells are completed within the lower confined bedrock aquifer (SpecPro Professional Services, 2018). In the AEC-provided database of well information, 399 of 733 wells had a well-depth assignment (A-F). However, there were many wells (typically, private wells) that did not have a well-depth assignment in the database but had well construction information that allowed a well-depth assignment to be made. By assigning a well-depth interval to these wells, the number of available wells for interpolation was increased. These wells were grouped with the 371 wells that already contained a depth assignment after the following three steps.

First, an approximate top of casing (TOC) elevation was assigned to wells for which a depth interval assignment was missing. Using a one-third arc-second digital elevation model from the USGS The National Map, the TOC elevations for these wells were drawn from the ground elevation digital elevation model (U.S. Geological Survey, 2017). For the wells within the plume areas of concern, a comparison between the TOC elevations provided by well surveying and the ground elevation derived from the digital model shows that the mean difference between these two values is $2.5 \mathrm{ft}$, with a standard deviation of $5.9 \mathrm{ft}$ and maximum difference of $22.0 \mathrm{ft}$. Considering the range of monitoring well depths at BAAP (20-555 ft below ground surface), the ground elevation derived from the digital elevation model was suitably accurate for well classification.

Second, a well screen midpoint elevation was calculated for all wells. Using the AEC-provided well depths, screen lengths, and the top of casing elevations, the elevation of the well screen midpoint was computed as

Screen Midpoint Elevation=TOC Elevation-[(Total Depth+(Total Depth-Screen Length))/2].

Third, from this screen midpoint elevation, a well depth classification was assigned to previously unassigned wells. Using the horizontal position and screen midpoint elevations, the screen midpoints were plotted in three dimensions using ArcScene 10.6 (Esri, 2016b). Wells without a well depth classification were manually assigned a classification (A-F) based on their three-dimensional proximity to previously assigned wells. Following the above three steps, the number of wells available for plume extent mapping was increased from 399 wells to 513 wells (table 4). All 513 wells were sampled at least once during the $2000-18$ period.

Table 4. The number of sampled wells used in analysis within each depth interval for each plume, Badger Army Ammunition Plant.

[A, well screen opening near the water table; B, well screen opening one-third from water table to bedrock; C, well screen opening two-thirds from water table to bedrock; D, well screen opening just above bedrock; E, well opening in the Eau Claire Formation; F, well opening in the lower confined bedrock formation; PBG, Propellant Burning Ground, DBG, Deterrent Burning Ground]

\begin{tabular}{lcccc}
\hline Well depth interval & $\begin{array}{c}\text { Number of wells used in } \\
\text { analysis }\end{array}$ & $\begin{array}{c}\text { Number in PBG plume } \\
\text { analysis }\end{array}$ & $\begin{array}{c}\text { Number in Central plume } \\
\text { analysis }\end{array}$ & $\begin{array}{c}\text { Number in DBG plume } \\
\text { analysis }\end{array}$ \\
\hline A & 158 & 79 & 43 & 36 \\
B & 142 & 59 & 24 & 59 \\
C & 103 & 64 & 21 & 18 \\
D & 57 & 39 & 3 & 0 \\
E & 47 & 35 & 1 & 9 \\
F & 6 & 5 & & 0 \\
\hline
\end{tabular}




\section{Wells Not Used in Plume Delineation Analysis}

Some wells included in the database were not used in the mapping analysis for one of two reasons. The first reason is that a well in the furnished database of chemical constituent data did not have any associated sampling data reported for $2000-18$. The second reason is that depth information was not available for the well and a well depth interval could not be assigned. A review of the location of the wells missing depth information showed that gathering depth information for these wells and including them would likely not change the result; the wells missing depth information are within clusters of other wells that have depth information and have been sampled.

\section{Delineation of Plume Boundaries}

For each contaminant, analysis period, and plume, the workflow in figure 2 was followed using the ArcMap Model Builder (Esri, 2016a). First, the subset of wells sampled during the given analysis period and within the given plume were selected. Second, a natural-neighbor interpolation of the chemical data for each contaminant at each depth interval was implemented, which created a 10 - by $10-\mathrm{ft}$ resolution raster of contaminant concentration. The 3-year period values (described above in "Aggregation of Data into Plume Analysis Periods") were used for this interpolation. Third, contour lines at the desired contaminant level (ES or PAL) were extracted. Fourth, the plume boundaries for all depth intervals (A-F) were overlaid, and the outer-most edge of all of the levels (that is, the spatial union) was taken as the map-view plume boundary. The plume boundary was then manually smoothed to remove interpolation artifacts, including physically unreasonable plume shapes. Finally, the plume boundaries were evaluated to determine whether all sides of the plume boundary were surrounded by wells with a 3-year value less than the ES for every depth interval in which there was an ES exceedance. If a well exceeding the contaminant ES was on the outer extent of the monitoring well network, then the contour line was drawn as a solid line along the well field boundary. If this criterion was not met, the line was dashed to indicate uncertainty over the exact positioning of the plume boundary because the sample well field may have determined the plume extent. An example of how the individual layer boundaries are combined to create a single overall plume boundary is shown in figure 3 .

\section{Method of Statistical Analysis of Trends in Wells and Plumes}

Individual wells were analyzed for trends in concentrations of selected contaminants over time, and the status of concentrations was compared to the ES and PAL cleanup goals for statistical significance of achieving these goals. This information was then used to evaluate overall trends in the three major plumes (table 1). The analysis was conducted using the Monitoring and Remediation Optimization System, version 3.0, (MAROS) (Vanderford and others, 2013). MAROS was developed for the Air Force by GSI Environmental Inc. (GSI) and is used to analyze trends in individual wells and in groundwater plumes for individual COCs. Using the statistical results of the well and plume trends, MAROS indicated recommended sampling frequencies for each monitoring well in the network and recommended additional sampling locations. MAROS also identified wells that could be considered for elimination, based on the redundancy of the information they provide. The most recent version of MAROS, version 3.0, was used for this analysis.

\section{Data Input Parameters for Statistical Analysis}

Site details used to inform MAROS of the plume characteristics are described in table 5. Seepage velocity, which varied by plume and porosity values, a constant of 0.26 for all plumes, were provided for each plume in the "2011 Alternative Feasibility Study Groundwater Remedial Strategy Badger Army Ammunition Plant" (SpecPro, Inc. and Badger Technical Services, LLC, 2011). Aquifer saturated thickness and groundwater flow direction were estimated from the same report. Average dimensions for each plume extent, as well as distance to and from downgradient receptors, were estimated from the plume delineation results in the current study. Cleanup goals were designated as Wisconsin State ESs and PALs. Because monitoring wells are present at all source areas, a value of $1 \mathrm{ft}$ was used as the distance from source to nearest downgradient receptor. Because detection limits change over time and could affect the calculated trends if NDs were assigned a different detection limit for each individual sample, it was necessary to assign a constant detection limit for each COC for each time period. This assigned LOD was set to one-half the median detection limit reported by the laboratory for each $\mathrm{COC}$ for each time period (table 6). Duplicate sample results were averaged, and when samples were flagged as trace values, the reported values were used.

MAROS software requires each well to be classified as a source, tail, or delineation well. Source wells are defined as those with historically high concentrations or those near a known source. BAAP has known contaminant sources at the PBG and DBG, so wells near these source areas with higher concentrations in the year 2000 were classified as source wells. In the Central plume, wells with higher concentrations near the upgradient end of the delineated plume boundaries were also classified as source wells. Tail wells are those with at least four detections of quantifiable concentrations and located downgradient from the source. Delineation wells are upgradient, downgradient, or cross-gradient from the source but have ND results or less than four detections because at least four detections are necessary to assess trends in concentration with statistical significance. Therefore, only source and tail wells were included in the trend analysis. For each well, a separate classification was assigned for each contaminant. The data were analyzed to assess trends for two time periods: 2000-12 and 2013-18. The most recent data available for the analysis were collected in October 2018. 
Receive data from Army Environmental Command (AEC)

- COC concentrations from 2000-18 - Well data

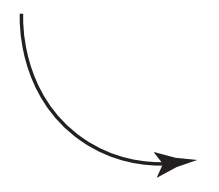

Aggregate data for 2000-02, 2005-07, 2010-12, and 2015-18 periods

Maximum of detected values in 3-year period is the interpolation value. If no detections in the 3 -year period, use minimum of half of detection limit as the interpolation value. If no laboratory results in 3-year period, exclude from analysis.

Select wells for each plume

- Propellant burning ground

- Central plume

- Deterrent burning ground

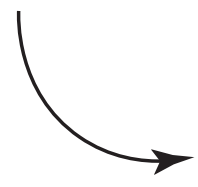

Assign depth intervals (if previously unassigned)

Use available well records and surface elevation data to create well midpoint elevation. Assign well intervals based on 3-D distance to nearby AEC-assigned wells

Perform natural neighbor interpolation

Interpolate among wells at each depth interval and COC separately; extract the contour at the enforcement standard each time.
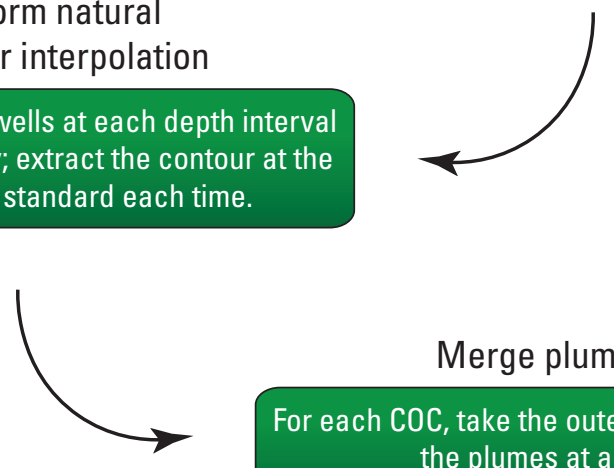

Merge plume boundaries

For each COC, take the outer boundary (spatial union) of the plumes at all depth intervals.

Smooth boundaries and evaluate delineation

Dash portions of the plume with un-delineated or with poorly delineated edges.

Figure 2. Diagram depicting the workflow for computation of plume boundaries. (COC, contaminants of concern, 3D, three-dimensional) 


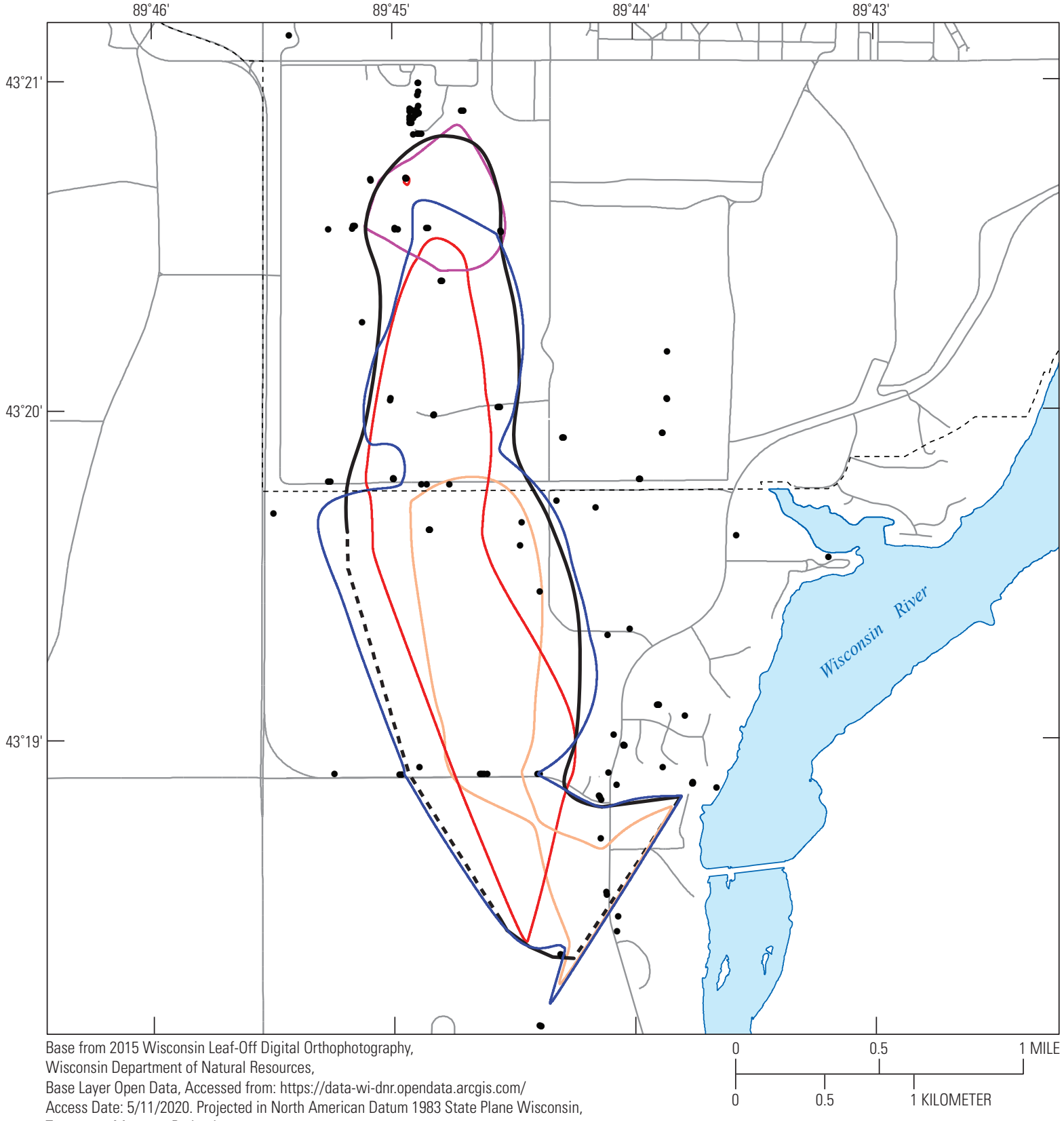

Access Date: 5/11/2020. Projected in North American Datum 1983 State Plane Wisconsin,

Transverse Mercator Projection.

\section{EXPLANATION}

_ Overall plume boundary
- - Uncertain overall plume boundary
2010-12 carbon tetrachloride propellant
burning ground plume-enforcement
standard

Figure 3. Propellant Burning Ground plume boundaries for carbon tetrachloride, Badger Army Ammunition Plant, 2010-12. Separate plume boundary delineations for different depth layers are combined to create the overall plume boundary. 


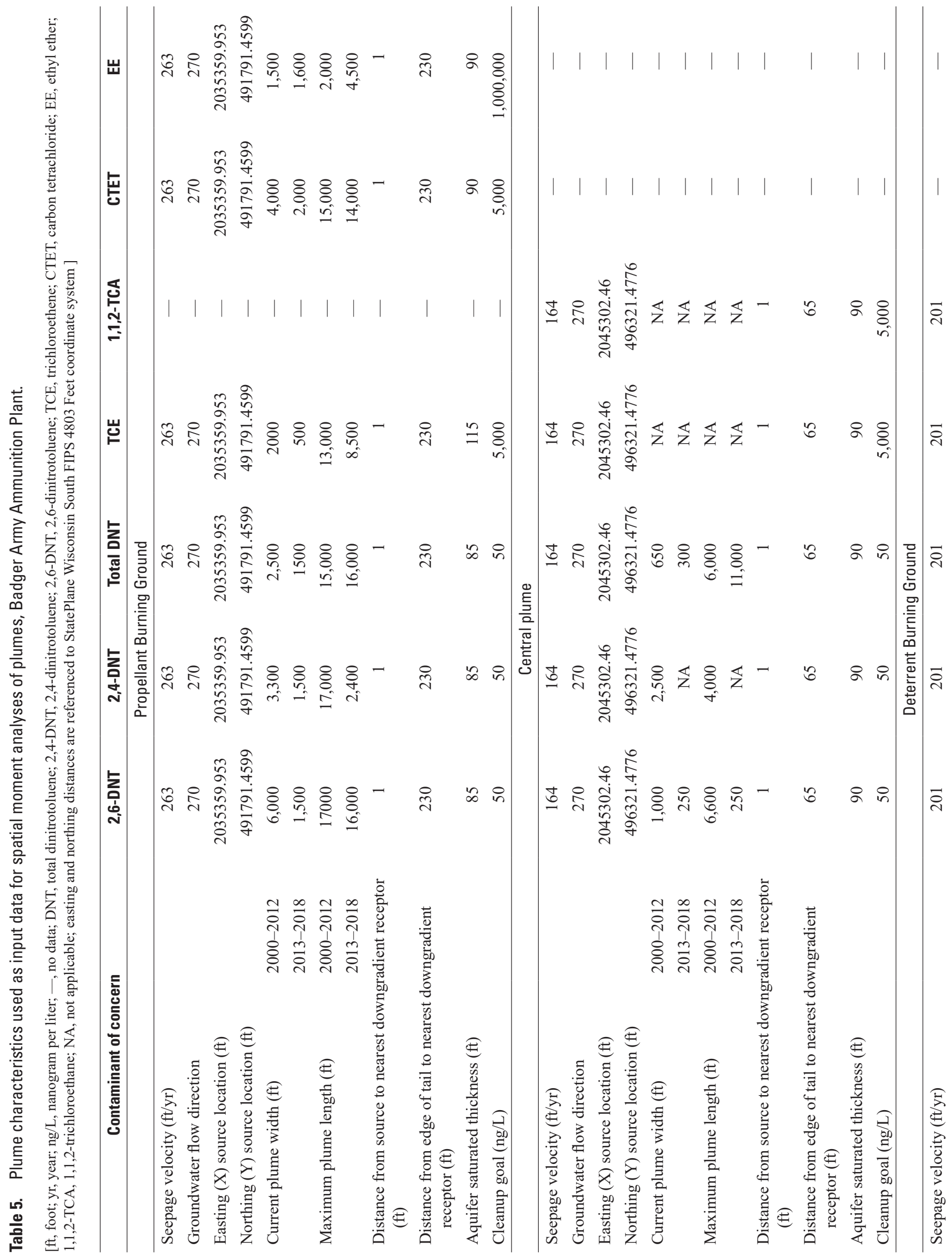




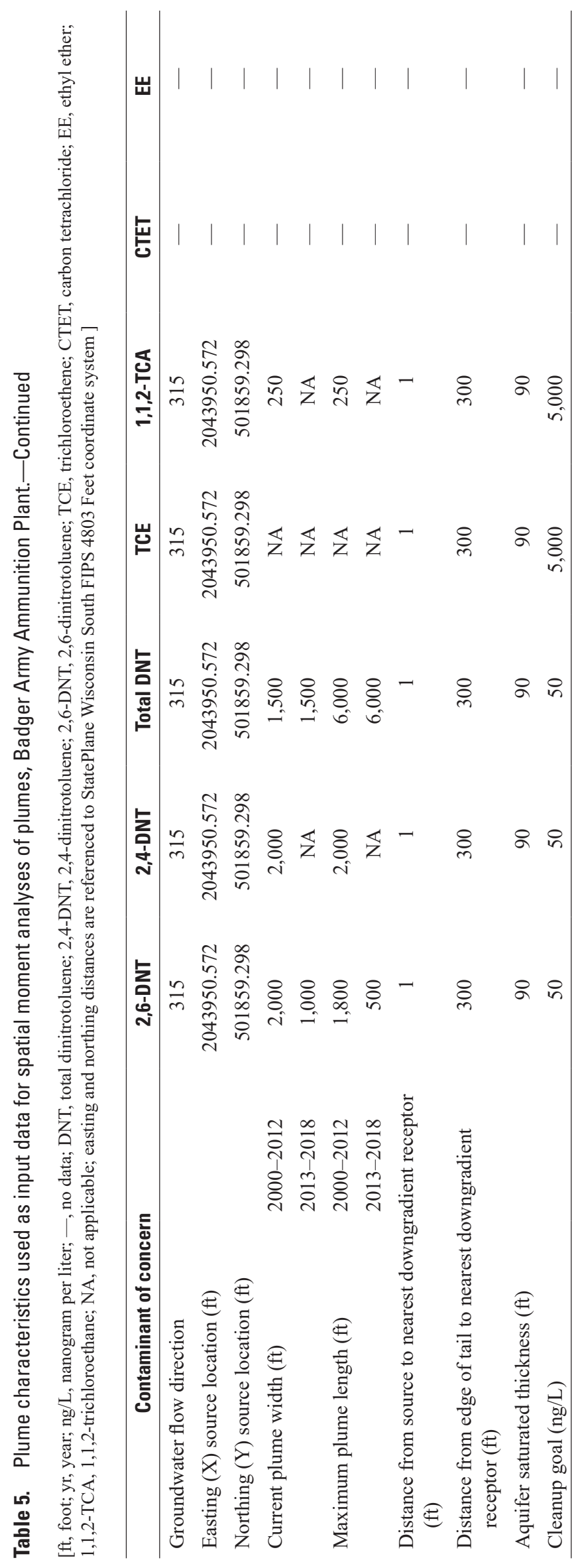


Table 6. One-half of median limit of detection for contaminants of concern for analysis periods 2000-2012 and 2013-2018, by plume.

[LOD, limit of detection; ng/L, nanogram per liter; DNT, total dinitrotoluene; 2,4-DNT, 2,4-dinitrotoluene; 2,6-DNT, 2,6-dinitrotoluene; TCE, trichloroethene; CTET, carbon tetrachloride; EE, ethyl ether; 1,1,2-TCA, 1,1,2-trichloroethane]

\begin{tabular}{|c|c|c|}
\hline \multirow{2}{*}{ Contaminant of concern } & \multicolumn{2}{|c|}{ One-half the median LOD (ng/L) } \\
\hline & $2000-12$ & 2013-18 \\
\hline \multicolumn{3}{|c|}{ Propellant Burning Ground plume } \\
\hline $\mathrm{EE}$ & 50 & 50 \\
\hline 2,6-DNT & 10 & 5 \\
\hline Total DNT & 5 & 5 \\
\hline TCE & 75 & 50 \\
\hline \multicolumn{3}{|c|}{ Central plume } \\
\hline $1,1,2-\mathrm{TCA}$ & 75 & 50 \\
\hline 2,6-DNT & 5 & 2 \\
\hline \multicolumn{3}{|c|}{ Deterrent Burning Ground plume } \\
\hline $1,1,2-\mathrm{TCA}$ & 75 & 50 \\
\hline 2,6-DNT & 5 & 2 \\
\hline 2,4-DNT & 5 & 4 \\
\hline Total DNT & 5 & 4 \\
\hline TCE & 75 & 50 \\
\hline
\end{tabular}




\section{Individual Well Analysis}

Statistical tests were applied to the water-quality data from each individual well. Trends in concentration over time were analyzed using the Mann-Kendall test, which statistically assesses whether a specific variable (in this analysis, contaminant concentration) has an upward or downward trend over time. The Mann-Kendall test is nonparametric, so it is well suited for data that are not normally distributed and have irregularly spaced measurement points, such as wells that were not sampled on a consistent schedule (Aziz and others, 2003). The strength of the trend was on the basis of confidence interval and coefficient of variation, and summarized in six categories: increasing (an upward trend in concentration over time), probably increasing, no trend, stable, probably decreasing (a downward trend in concentration over time), and decreasing (table 7). (These categories are consistent with terminology used in output generated by the MAROS software. As used in this report, "increasing" refers to an upward trend in concentration, and "decreasing" refers to a downward trend in concentration.) A value of Not Applicable (NA) indicates insufficient data were available to conduct the test (that is, fewer than four detections of a COC in a well).

A data sufficiency analysis was also performed using a power analysis and sequential t-test (U.S. Environmental Protection Agency, 1992) to determine whether a well has reached or is reaching the cleanup goal (ES and PAL) with statistical significance. The results are reported as (1) attained, if the mean concentration is significantly less than the cleanup goal, (2) not attained, if the mean concentration is greater than the cleanup goal, (3) continue sampling, if the mean concentration is less than the cleanup goal but not with statistical significance, or (4) not conducted owing to insufficient data.

Table 7. Criteria for assigning concentration trends and confidence based on Mann-Kendall Statistical results. Modified from Aziz and others (2003).

[S, Mann-Kendall statistic; COV, coefficient of variation; <, less than; >, greater than; $\geq$, greater than or equal to]

\begin{tabular}{lll}
\hline \multicolumn{1}{c}{ Mann-Kendall statistic } & \multicolumn{1}{c}{ Confidence in trend } & \multicolumn{1}{c}{ Concentration trend } \\
\hline $\mathrm{S}>0$ & $>95$ percent & Increasing \\
$\mathrm{S}>0$ & $90-95$ percent & Probably increasing \\
$\mathrm{S}>0$ & $<90$ percent & No trend \\
$\mathrm{S} \leq 0$ & $<90$ percent and COV $\geq 1$ & No trend \\
$\mathrm{S} \leq 0$ & $<90$ percent and COV $<1$ & Stable \\
$\mathrm{S}<0$ & $90-95$ percent & Probably decreasing \\
$\mathrm{S}<0$ & 95 percent & Decreasing \\
\hline
\end{tabular}




\section{Plume Analysis}

Spatial moment analysis was used to assess the stability of each plume for the contaminants of concern. The zeroth moment is an estimate of the change in total mass of a contaminant over time within the plume. The first moment provides an estimate of the change in distance from the source location to the center of mass of a contaminant plume. The second moment estimates the spread of the length (x direction) and width (y direction) of a contaminant plume over time. Trend results were classified into one of six categories on the basis of the strength of the trend using the Mann-Kendall statistic: increasing, probably increasing, no trend, stable, probably decreasing, and decreasing. The same confidence intervals shown in table 7 were applied to the plume trend analyses. A value of NA indicates insufficient data were available to conduct the test.

Data can be consolidated in various ways to format the raw data for analysis in MAROS. For the individual well trends, the data were not consolidated. The plume analysis requires a minimum of six wells within each sample event. Because the frequency of sampling events varied across the network, data were consolidated to annual events, and the maximum value for a given well was selected to represent each annual dataset. Just as the plume delineations were evaluated in horizontal slices on the basis of depth interval, the plume analyses also were evaluated using the same methodology, allowing characterization of plume trends at each depth interval.

\section{Monitoring Network Optimization}

An evaluation of both the spatial and temporal components of the monitoring network was conducted to optimize sampling location and frequency using the MAROS software. To evaluate the optimal density and sampling location of wells used to monitor a plume, the software combines a spatial geometry method using Delaunay triangulation and Voronoi diagrams (George and Borouchaki, 1998; Aziz and others, 2003 ) with a qualitative decision logic method to recommend wells for elimination from the monitoring network and to identify locations where additional sampling locations may be needed. To evaluate optimal sampling frequency, the software uses the Modified Cost-Effective Sampling protocol (Ridley and others, 1995) to evaluate sampling frequency at individual wells on the basis of the history of concentration data and recommends a network-level sampling frequency on the basis of the rate of change in mass of a plume contaminant.

\section{Assessment of Contaminant Trends in Plumes and Wells}

Plumes were mapped for each of the COCs for which adequate data were available in a given time period, and statistical analyses were performed on water-quality data at individual wells and at the scale of each plume.

\section{Plume Delineations}

For the four designated periods, the three major plumes, and the seven COCs (84 possible combinations), ES plume boundaries were determined for 36 combinations (table 2). For nine of the possible combinations, there were no laboratory results available. For 39 of the possible combinations, the ES was not exceeded, so a plume map could not be drawn on the basis of the ES. However, it was possible to delineate boundaries on the basis of the PAL criteria for 13 of the 39 combinations for which the ES was not exceeded. Plume boundaries based on PAL criteria are shown on the maps when available.

\section{Propellant Burning Ground Plume}

The PBG plume covers the largest area of the three major plumes and includes exceedances of the ES for trichloroethene (TCE), carbon tetrachloride (CTET), 2,4-dinitrotoluene (2,4-DNT), 2,6-dinitrotoluene (2,6-DNT), total DNT, and ethyl ether. Because 1,1,2-trichloroethane (1,1,2-TCA) did not exceed the ES or PAL in any sample, no plume boundary was drawn for it. The monitoring well network in place to monitor the plume has a high spatial density on the BAAP installation, whereas to the south of the installation boundary, there are fewer monitoring wells, leading to more uncertainty in the lateral extent of the plume. Plates 1 through 6 display the plume maps for each COC.

The most important results identified in the plume maps are as follows.

1. The downgradient edge of the plume is not well defined in the 2010-12 and 2015-18 periods, particularly for TCE (plate 1), CTET (plate 2), 2,6-DNT (plate 4) and total DNT (plate 5) because the ES was exceeded in wells PBM-9001D and PBN-9101C, and no other concentration data were available from nearby wells in the same depth intervals. The plume width within the uncertain (dashed) area varies with the observed concentrations and the well sampling network. Plume maps from previous reports extend the plume boundary to the Wisconsin River on the basis of groundwater samples taken from borings close to the river in 2013 (Badger Technical Services, 2013c). For this analysis, plume boundaries were not extrapolated beyond the monitoring 
well network because water-quality data were not available from the boring locations for any other time period (Badger Technical Services, 2013c).

2. The TCE, CTET, 2,4-DNT, and 2,6-DNT plumes develop into separate, smaller ES exceedance areas by the 2015-18 analysis period (plates 1 through 4). This may reflect spatially discontinuous degradation in the plume body or the possible source control effects of IRM and MIRM extraction well pumping, which were operational from 1990 to 2012 (IRM) and 1996 to 2015 (MIRM) (SpecPro Professional Services, 2018). See "Comparison of Trends to Past Remedial Actions" section.

3. The CTET plume during 2010-12 is wide and dashed on the western downgradient one-third owing to exceedances in the B layer (well SWN-9103B) (plate 2). A lack of B layer wells in the downgradient one-third of the plume led to this uncertainty in the cross-gradient plume boundary. Geologic cross sections presented for this location (D-D' cross section shown in fig. 4) in previous reports show an east-west continuous gravel unit, which may affect contaminant movement differently than the $\mathrm{C}$ and D layers in this area (SpecPro, Inc. and Badger Technical Services, 2011; SpecPro Professional Services, 2018). This geologic unit supports the assertion that the cross-gradient boundary at this part of the CTET plume is not well delineated. A similar effect is observed in the TCE PAL plume (plate 1).

4. The eastern plume boundary for CTET in the upgradient end of the plume near the source area is poorly delineated in the A depth layer, particularly in the 2015-18 period (plate 2D).

5. The PAL boundary for CTET (plate 2) is poorly defined for all time periods because of exceedances observed on the edge of the monitoring well network. A lack of sampled wells in the D layer in the southeast corner of the plume creates uncertainties in both the PAL and ES plume boundaries for all time periods.

6. The plume boundaries for 2,4-DNT (plate 3 ) and 2,6-DNT (plate 4) are poorly delineated for 2000-02 because of detections of concentrations exceeding the ES at the edge of the well field. The resulting plume maps are dashed and angular to reflect that uncertainty.

7. For all DNT COCs (plates 3, 4, and 5), the crossgradient plume boundary is not well defined near the plume source area during any of the time periods. Few A or B layer wells with detections less than the ES are present on either side of the source area, which prevented a better-defined delineation. Few $C$ layer wells with detections less than the ES are present in these areas for the 2015-18 period.
8. Generally, the extent of the groundwater plumes decreases over time for each COC. The exception is the ethyl ether plume (plate 6), which could not be delineated for 2005-07 and which increased in length from 2010-12 to 2015-18. However, a lack of D layer wells downgradient from well PBN-9903D leads to an area south of the installation boundary that requires interpolation across a large distance. The large distance does not create the same uncertainty as when an exceedance is at the edge of the well network with no outer wells for interpolation, so the southern plume boundary line is not dashed.

9. The length and width of the plumes of TCE, CTET, total DNT, and ethyl ether delineated for the 2015-18 period in this analysis are larger than the plume boundaries drawn using 2017 data (SpecPro Professional Services, 2018). The plume extents could be larger for two reasons. First, the interpolation values used in this study are maximum concentrations detected from 2015 to 2018. Second, the natural-neighbor interpolation technique used in this analysis might be a more conservative technique than the plume-delineation method used by SpecPro.

\section{Central Plume}

The DNT contaminants were detected at greater than the ES within the Central plume. Two detections of TCE and CTET at greater than the PAL were observed, though these do not indicate a widespread presence of these contaminants. Plates 7-11 present the plume boundaries delineated for the Central plume. The most important results identified in the Central plume maps are summarized below.

Concentrations of 2,4-DNT exceeded the PAL in wells NLN-1001C and NLN-1001A in the 2010-12 time period (plate 9). There are few wells in the area to inform the plume delineation, so the interpolated boundary is extensive in the A depth layer and unbounded in the $\mathrm{C}$ depth layer. Sample concentrations in these wells were less than the ES for all other time periods, so this plume area is anomalous.

During the 2015-18 period, a well cluster in the northeast part of the well field had detection limits greater than twice the ES for 2,4-DNT, so the wells are identified as exceeding the ES (plate 9). Because these exceedances are solely related to the laboratory detection limits, these wells were excluded from the plume boundary contouring during this time period. These wells were not analyzed for total DNT in the 2015-18 period (plate 11). They are not listed as wells removed from the sampling program after 2010 because the wells have sample analytical results for 2,4-DNT and 2,6-DNT (see criteria listed in the Effect of Network Well Removal on Plume Boundary Delineation section).

Concentrations of the DNT compounds exceeding the ES in the Central plume are sporadic and occur mostly in the B and $\mathrm{C}$ depth layers. Well SEN-0503B has exceedances of 2,6-DNT 


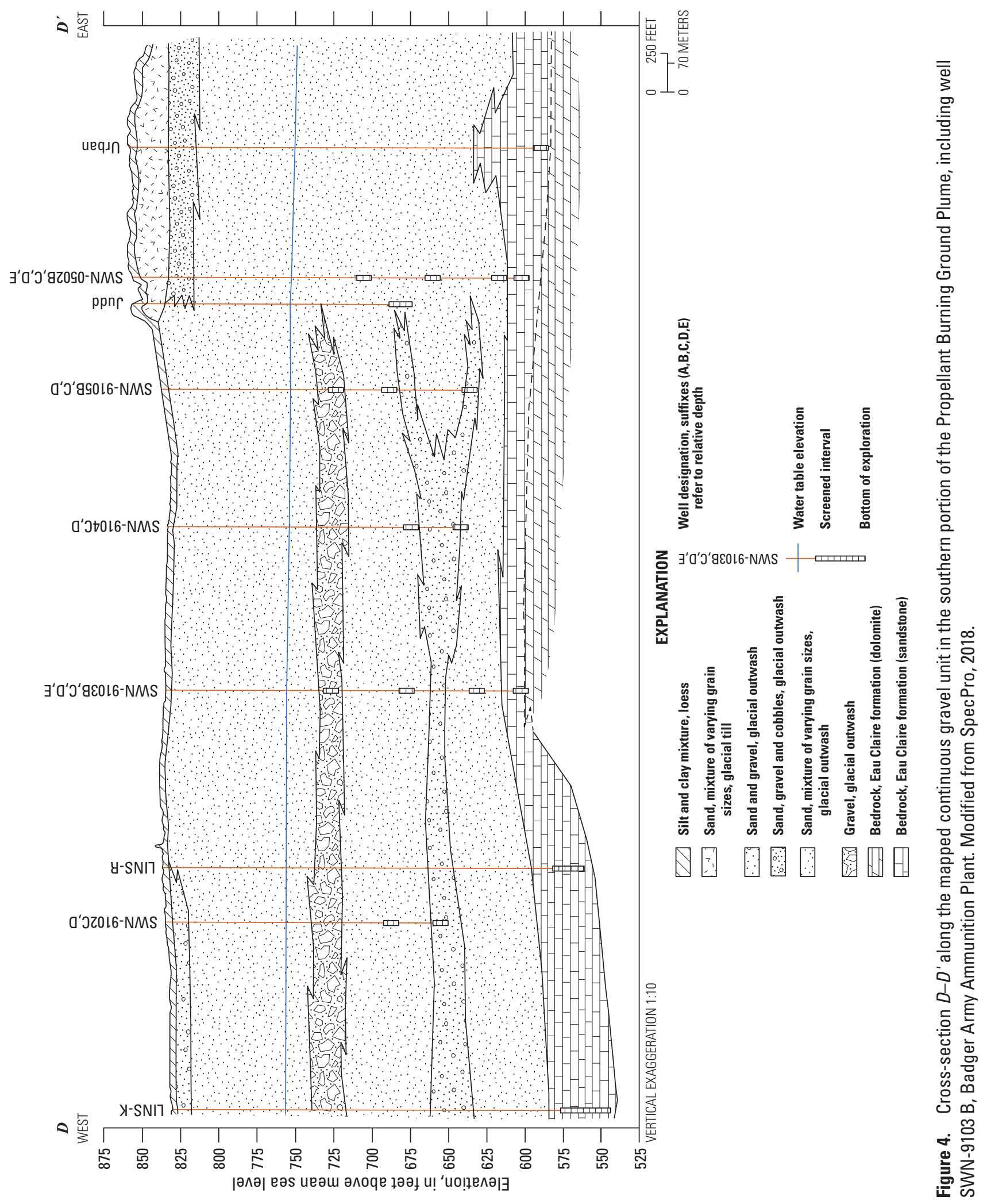


(plate 10) and total DNT (plate 11) and is located near the private wells along the Wisconsin River. The density of sampled wells allows the plume to be delineated in this area.

Although continuous plumes for 2,6-DNT and total DNT are displayed at the downgradient tail end of the plume for the 2015-18 period, the large spacing of wells with exceedances and the proximity of other wells with contaminant concentrations less than the ES make the degree of connectedness between the wells vary at different times (plates 10 and 11). For example, for the 2005-07 and 2010-12 periods, contouring the 2,6-DNT concentrations using the naturalneighbor interpolation creates individual plume segments in the B layer rather than a connected plume boundary because nearby wells with concentrations less than the ES separate the wells with ES exceedances (plate 10). The southernmost exceedance for 2,6-DNT and total DNT (0.068 microgram per liter $[\mu \mathrm{g} / \mathrm{L}]$ for both contaminants) in well 3497432 slightly exceeds the ES, so the plume boundary around the well is smaller than the well symbols in plates 10D and 11D and disconnected from the plume boundary around other wells.

\section{Deterrent Burning Ground Plume}

In the DBG, exceedances of the ES were observed for the DNT contaminants and 1,1,2-TCA. TCE was detected at greater than the PAL but less than the ES. Plates 12-16 present the plume boundaries delineated for each COC in the DBG plume. A summary of the most important results identified in the plume maps is presented below.

1. TCE concentrations exceeding the PAL were observed in wells on the southern edge of the well field in the A layer during the 2005-07, 2010-12, and 2015-18 periods (plate 12). The concentrations ranged from 0.36 to $4.7 \mu \mathrm{g} / \mathrm{L}$. These sporadic detections do not indicate a widespread plume area because they are adjacent to other A layer wells without exceedances of the PAL.

2. The downgradient edge of the ES plume boundary is not delineated for the 2015-18 period for total DNT (plate 15). No C layer well downgradient from well ELN-1003C was sampled during 2015-18 to provide the plume delineation.

3. For the DNT contaminants, the upgradient area of the plume boundary could not be accurately delineated for some time periods because no well within layer A had a concentration of DNT less than the ES. This condition occurs for 2,4-DNT (2000-02), 2,6-DNT (2000-02, 2005-07, and 2015-18) and total DNT (2015-18).

4. During 2015-18, the number of wells used for delineation in the DBG plume decreased from previous periods. Exclusion of wells to the west and southwest of BAAP changes the shape of the A layer well network, affecting the shape of the plume delineation for total DNT (plates $15 \mathrm{C}$ and $\mathrm{D})$. However, for the plume boundary in the vicinity of well DBM-9501, this effect is an artifact of the plume delineation methodology, and removing well DBM-9501 does not affect the certainty of the plume delineation from 2010-12 to 2015-18.

5. For 1,1,2-TCA (plate 16), the concentration in only one well exceeded the ES and only during 2010-12. The PAL plume boundary is not certain on the northeast boundary because there is no $\mathrm{C}$ layer well in this area to constrain the extent of the plume.

The plume boundary for total DNT for the 2015-18 period (plate $15 \mathrm{D}$ ) has approximately the same length along the gradient as plumes drawn using 2017 data (SpecPro Professional Services, 2018), but it has a greater cross-gradient width. The boundaries are likely different due to two primary factors. First, the interpolation value used in this study is the maximum value detected from 2015 to 2018. Second, boundary differences could be attributed to differences in the interpolation technique used.

\section{Statistical Analysis of Contaminant Trends in Plumes and Individual Wells}

The number of wells that could be analyzed for trends varied for each $\mathrm{COC}$ for several reasons. A minimum of four COC detections in a well is required for the individual well trend analysis, and at least six wells with trend analysis in the monitoring network are required to perform the plume analysis. In addition, some wells had all non-detects for some COCs but had detections for other COCs. Therefore, a single well may be classified as a source or tail well for one or more COCs but as a delineation well for others. Analysis of trends for at least one COC was performed for 235 of 616 individual wells that were classified as source or tail wells. For the 2000-12 period, trend analysis was performed for 184 individual wells; for the 2013-18 period, 160 wells were analyzed for trends (Metes and others, 2020). Spatial moment analyses of plumes were attempted for each $\mathrm{COC}$ at each depth interval that had at least six wells with detections per sampling event.

Results are summarized separately for each major plume for individual well analysis (Mann-Kendall trend and cleanup goal attainment) and for spatial moment analysis. Results for individual well and plume analysis trends are summarized in tables $8-10$ and figures $5-11$. Depth intervals with no results in the tables indicate insufficient data to conduct the analysis. There was no regulatory standard in Wisconsin for total DNT prior to January 2011, and no analytical results are available for this COC prior to 2011. The lack of total DNT data precludes the calculation of a trend for total DNT for all three plumes in the 2000-12 period. However, trends for total DNT in individual wells were calculated when adequate data were available (that is, at least four sampling events during 2011-12 with a detection). 


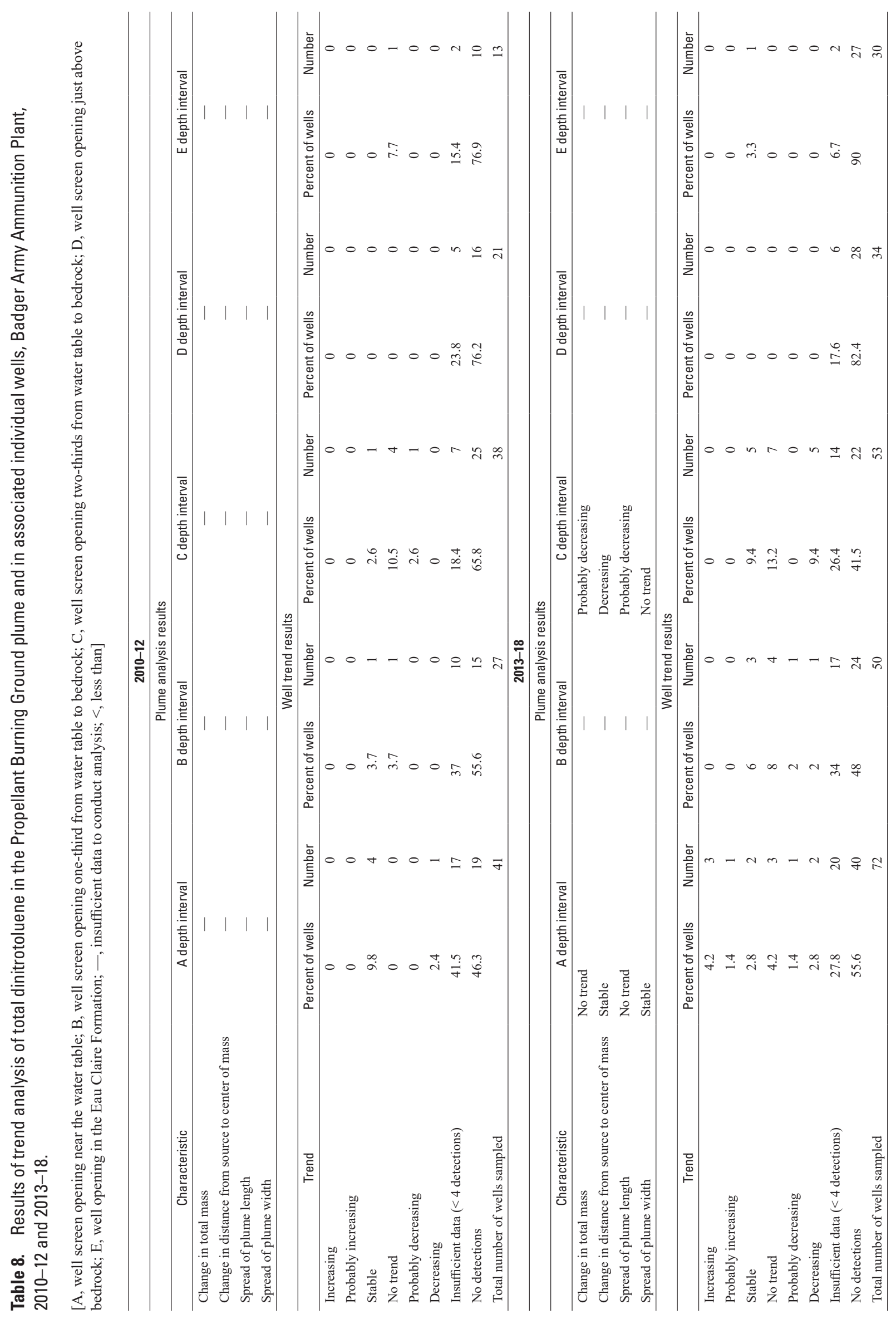




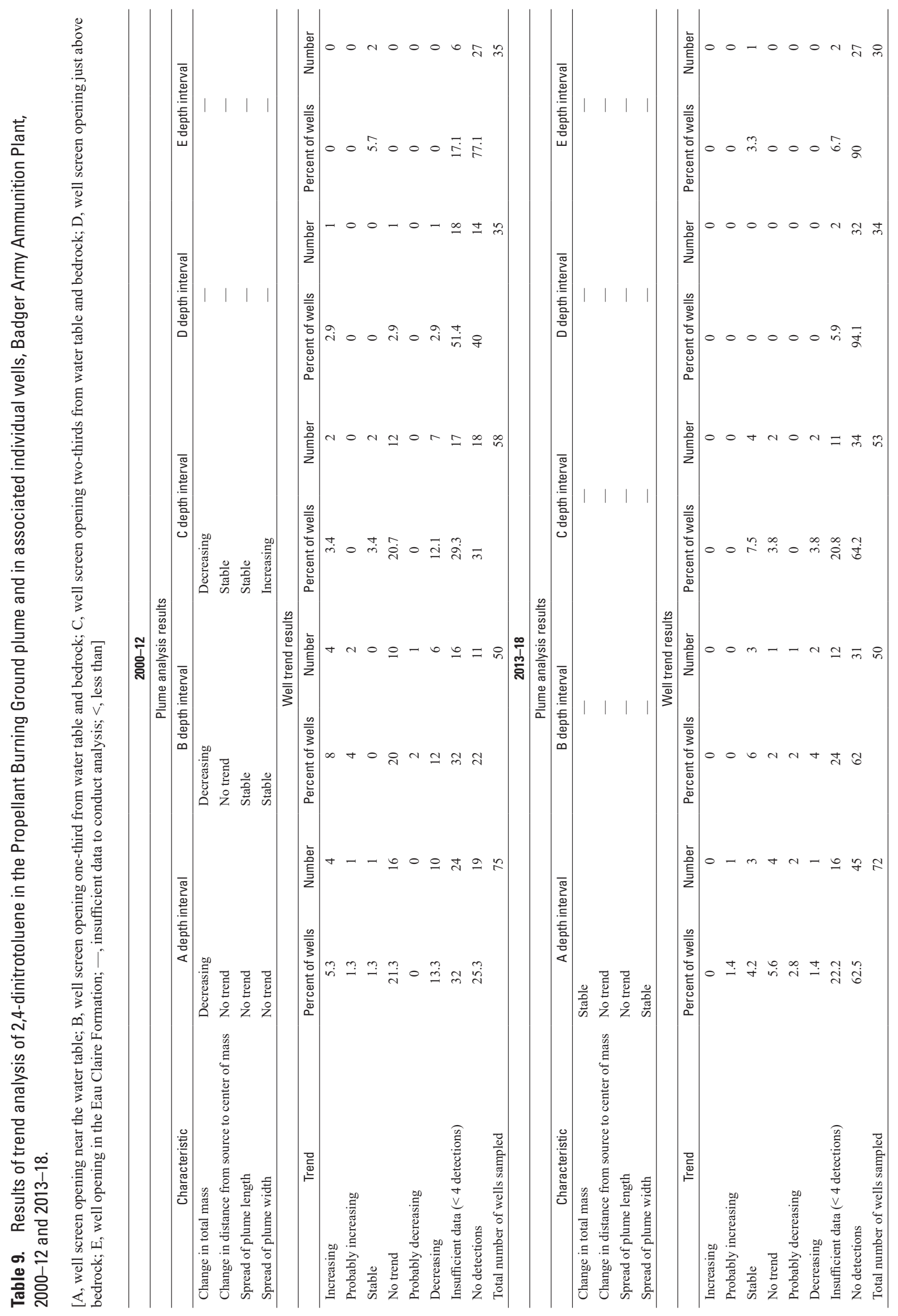




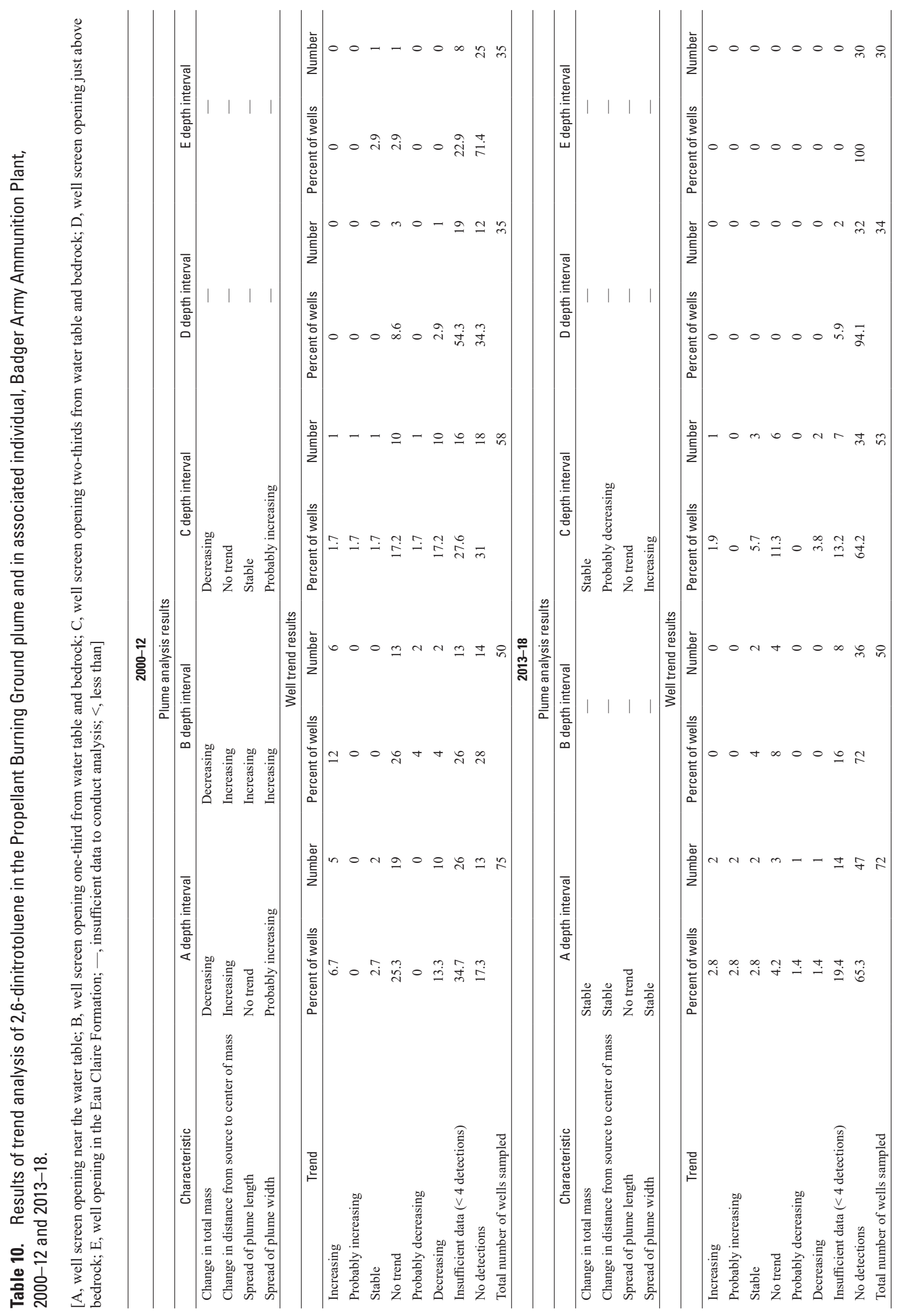




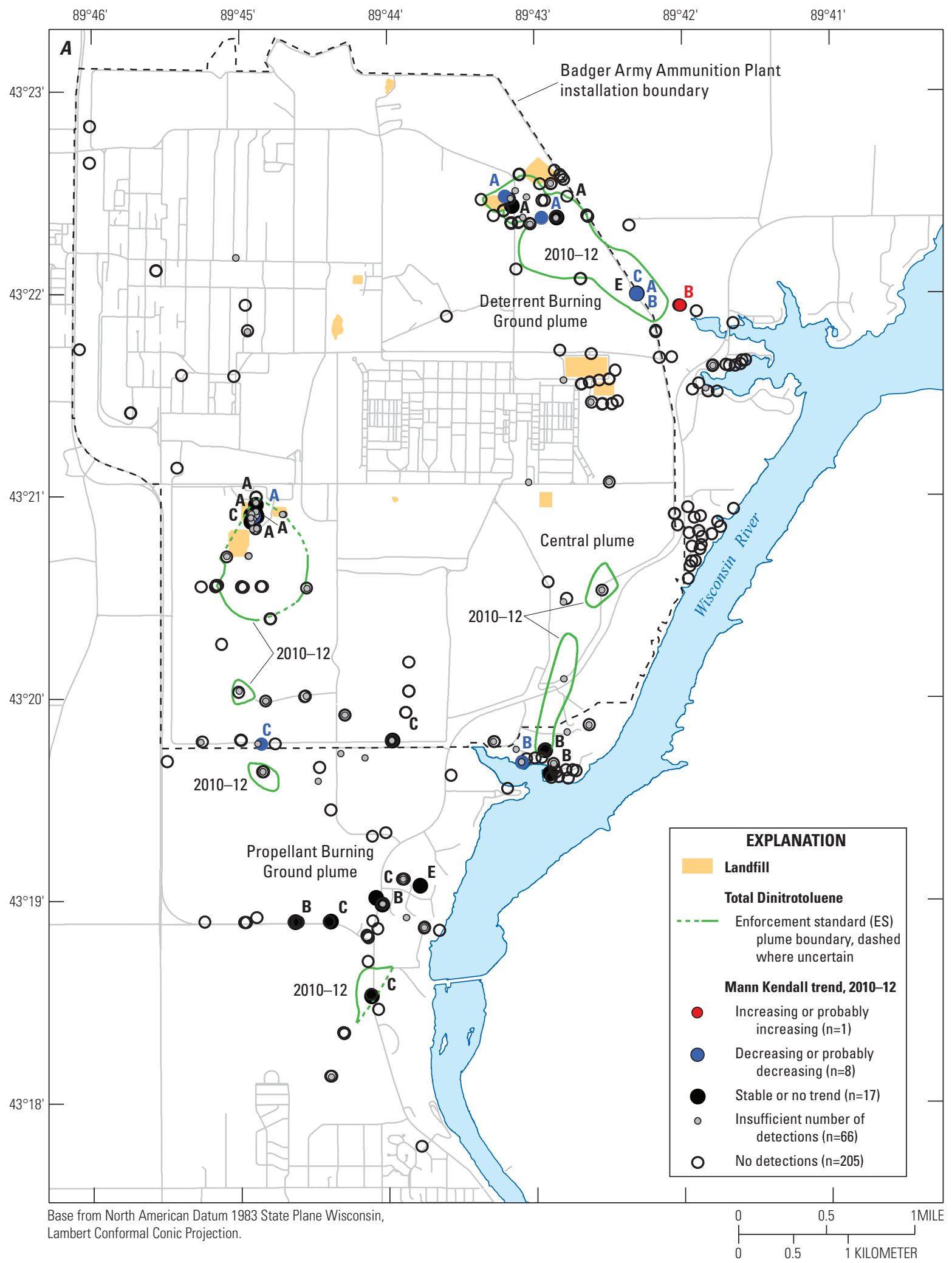

Figure 5. Map showing total dinitrotoluene plume delineations and concentration trends, Badger Army Ammunition Plant, for $A$, 2010-12 and B, 2013-18. (DNT, total dinitroluene; $\mathrm{A}$, well screen opening near the water table; $\mathrm{B}$, well screen opening one-third from the water table to bedrock; $C$, well screen opening two-thirds from the water table to bedrock; D, well screen opening just above bedrock; and E, well opening in the Eau Claire Formation. (ES, Enforcement Standard; BAAP, Badger Army Ammunition Plant) 


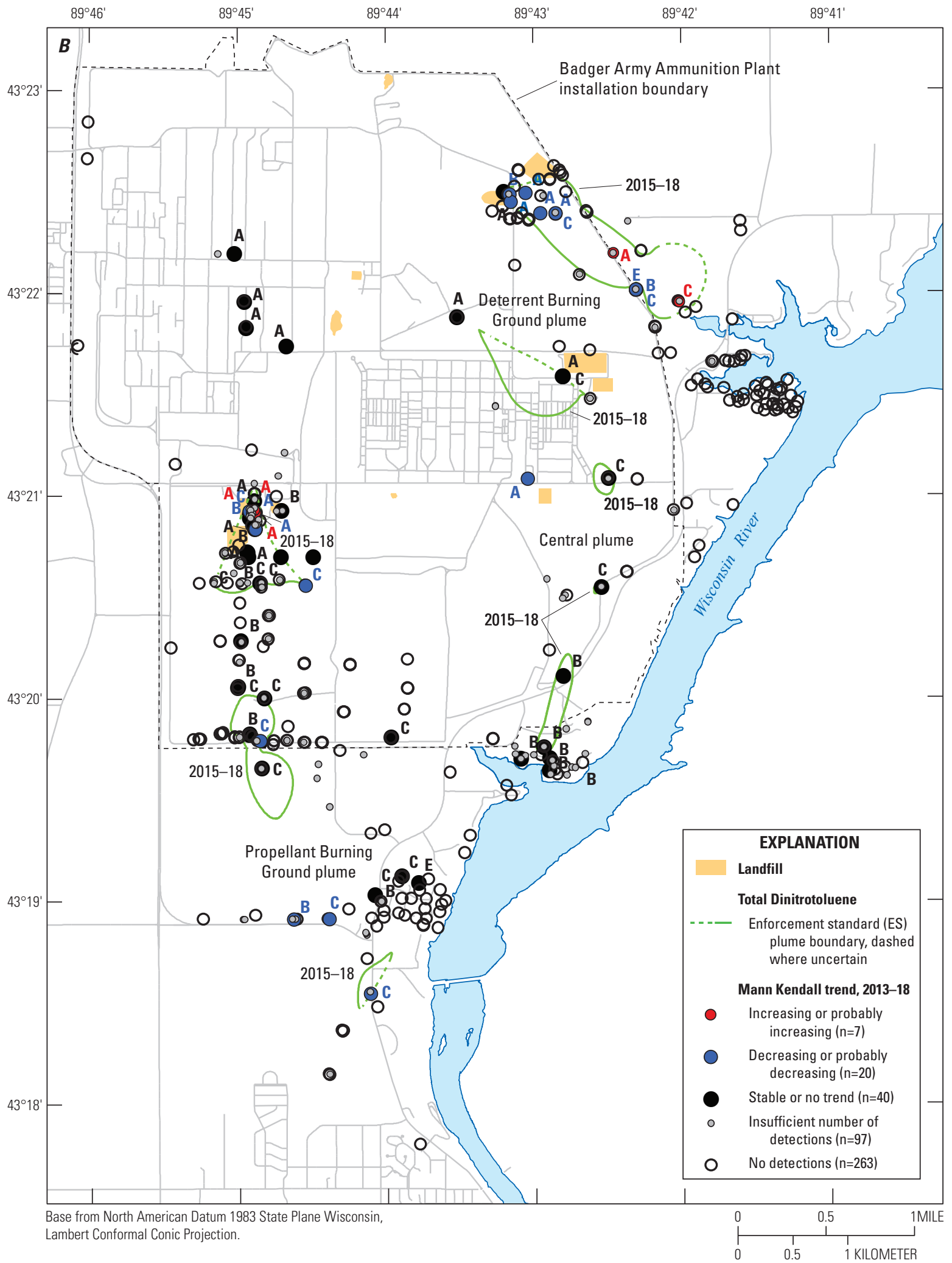

Figure 5.-Continued 


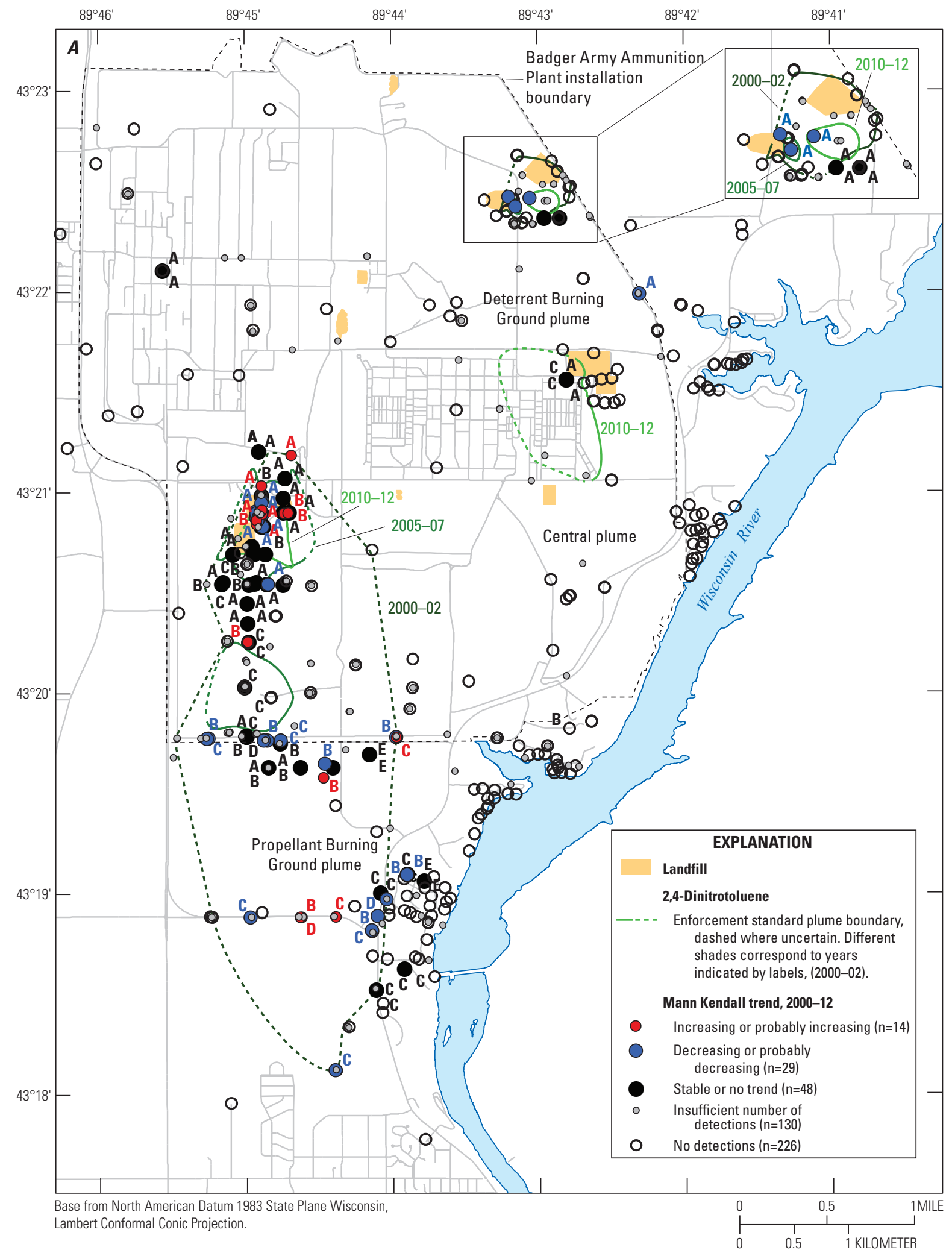

Figure 6. Map showing 2,4-dinitrotoluene plume delineations and concentration trends, Badger Army Ammunition Plant, for $A$, 2000-12 and B, 2013-18. (2,4-DNT, 2,4-dinitroluene; $A$, well screen opening near the water table; $B$, well screen opening one-third from the water table to bedrock; $C$, well screen opening two-thirds from the water table to bedrock; D, well screen opening just above bedrock; E, well opening in the Eau Claire Formation. (ES, Enforcement Standard; BAAP; Badger Army Ammunition Plant) 


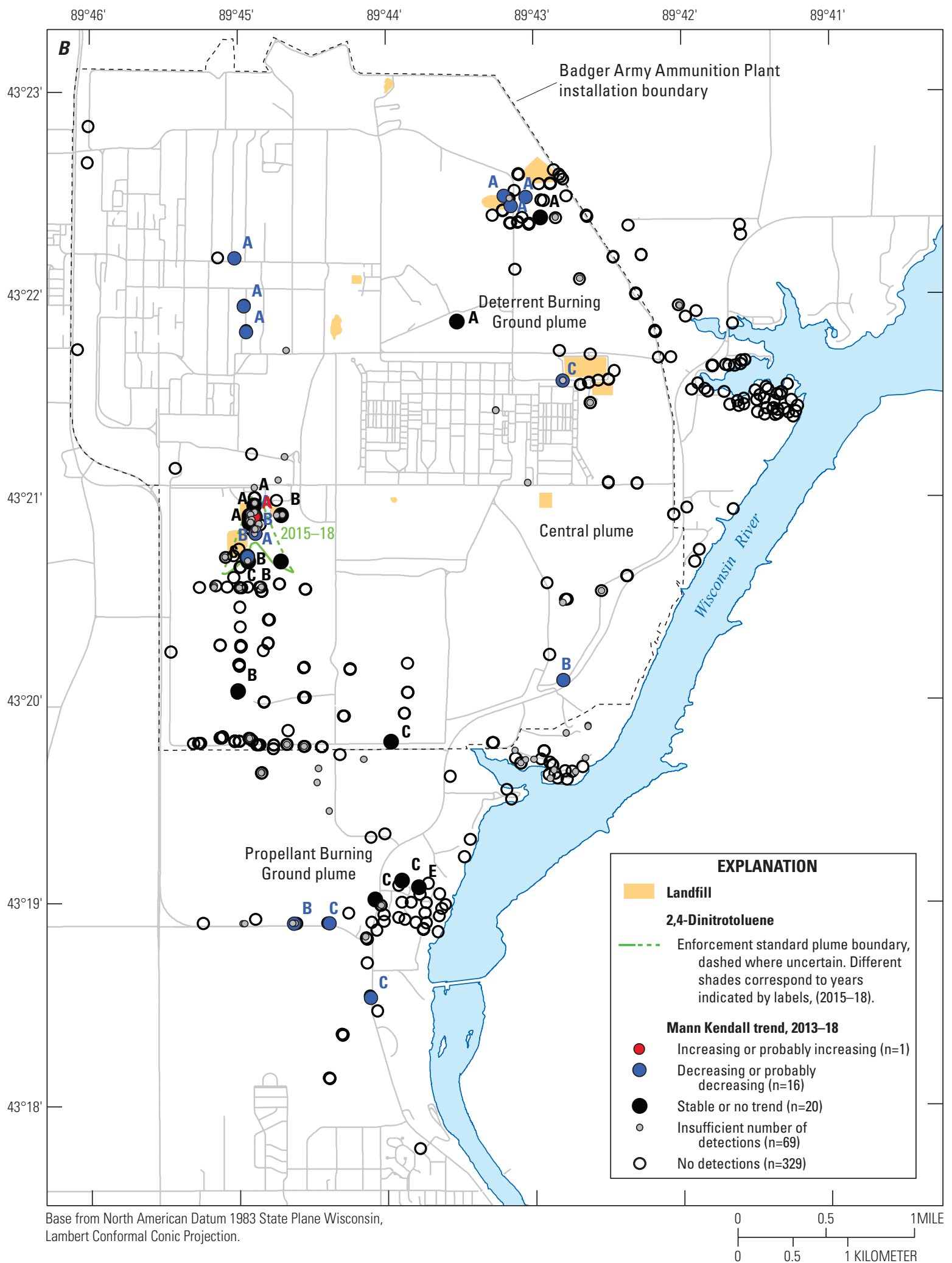

Figure 6.-Continued 


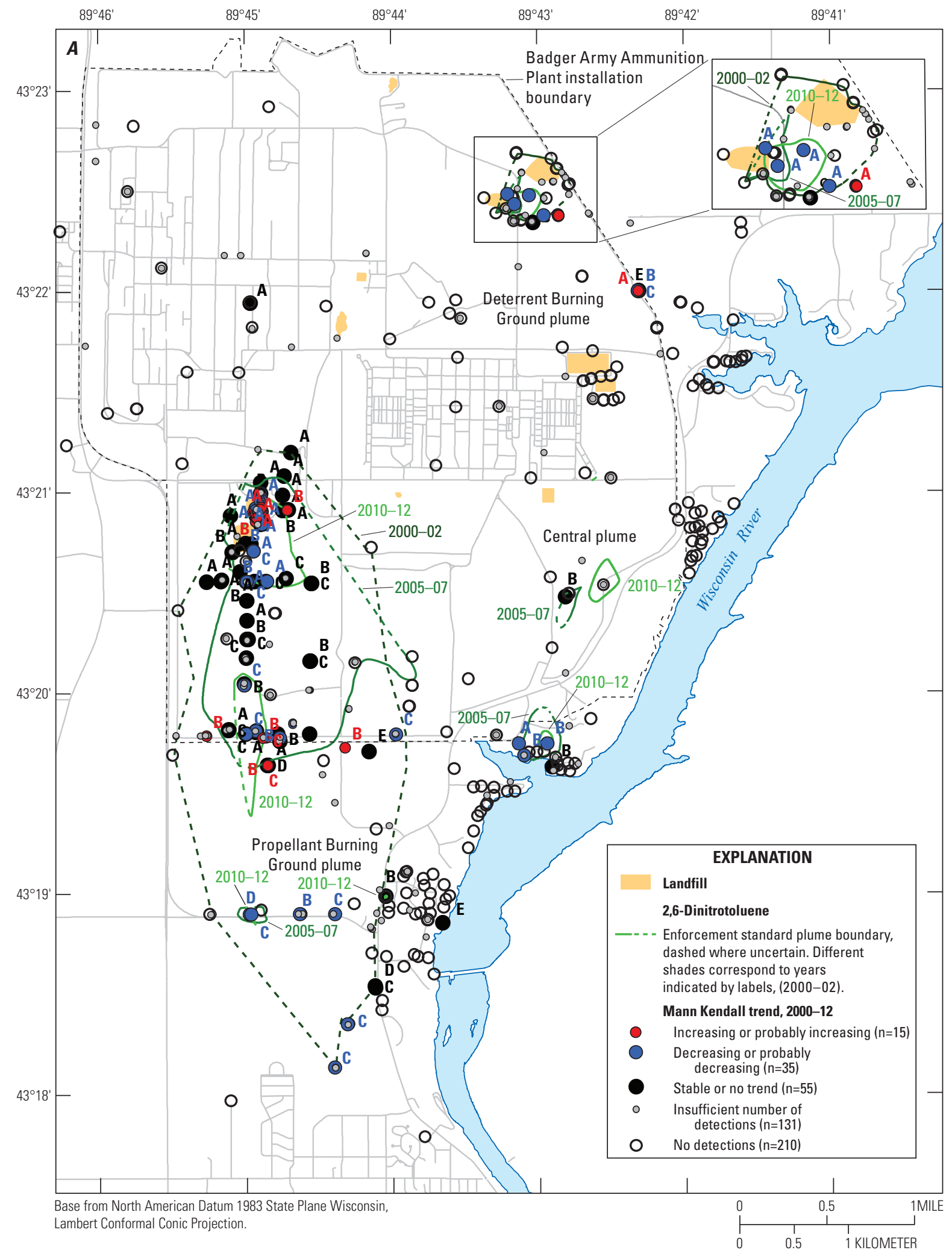

Figure 7. Map showing 2,6-dinitrotoluene plume delineations and concentration trends, Badger Army Ammunition Plant, for $A$, 2000-12 and B, 2013-18. (2,6-DNT, 2,6-dinitroluene; $A$, well screen opening near the water table; $B$, well screen opening one-third from the water table to bedrock; $C$, well screen opening two-thirds from the water table to bedrock; D, well screen opening just above bedrock; E, well opening in the Eau Claire Formation. (ES, Enforcement Standard; BAAP; Badger Army Ammunition Plant) 


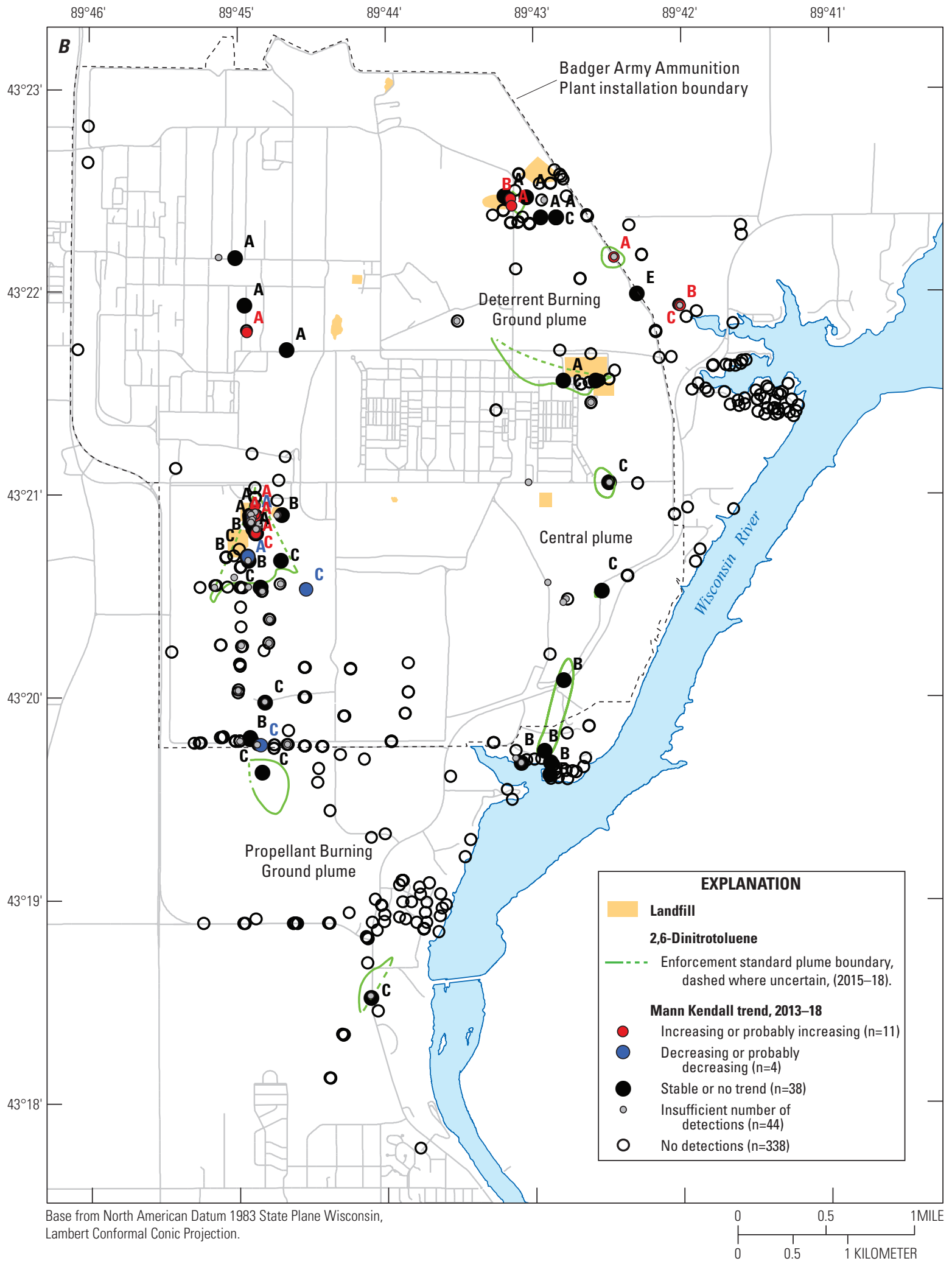

Figure 7.-Continued 


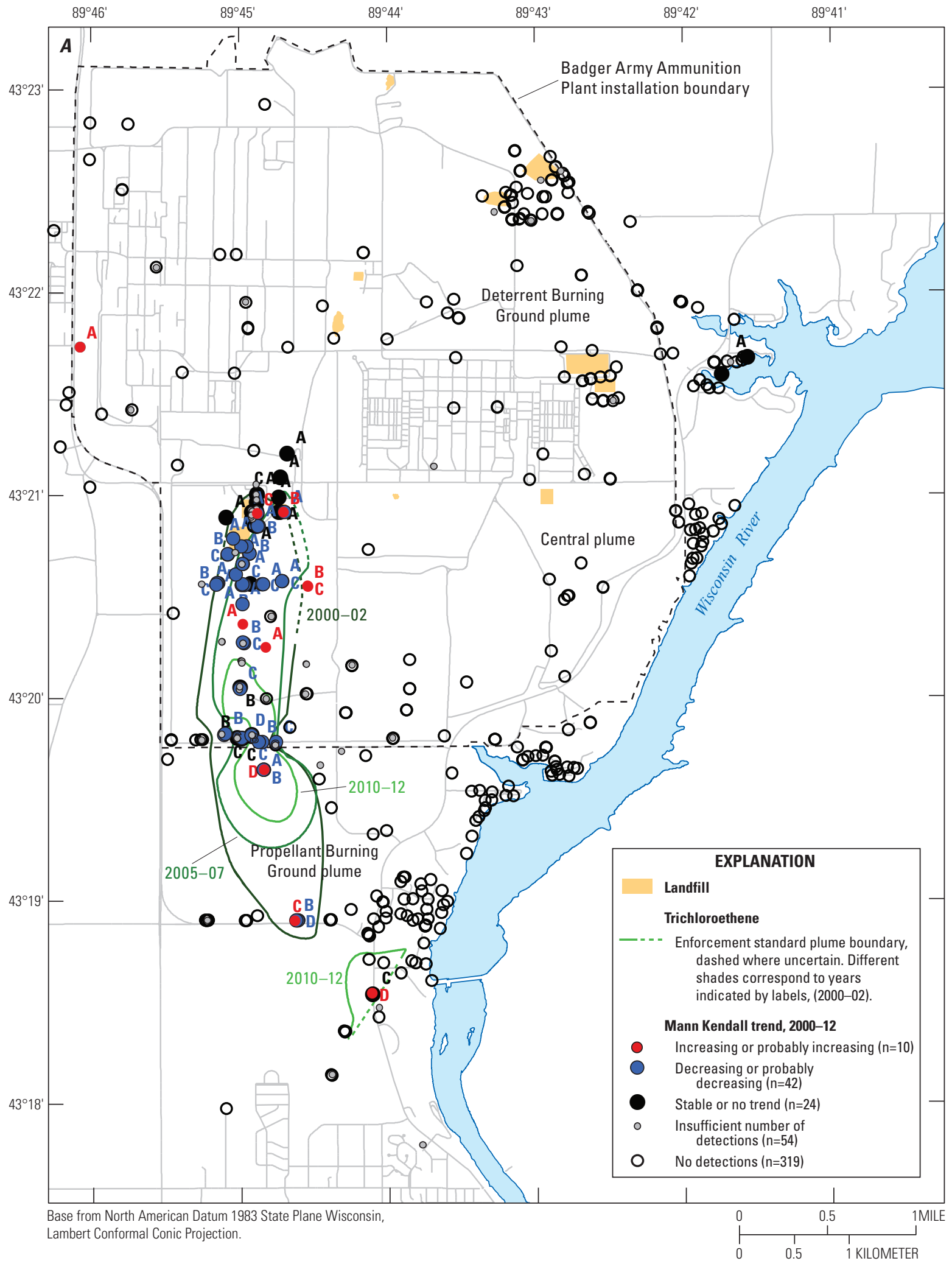

Figure 8. Map showing trichloroethene plume delineations and concentration trends, Badger Army Ammunition Plant, for $A, 2000-12$ and $B, 2013-18$. (TCE, trichloroethene; $A$, well screen opening near the water table; $B$, well screen opening one-third from the water table to bedrock; $C$, well screen opening two-thirds from the water table to bedrock; $D$, well screen opening just above bedrock; E, well opening in the Eau Claire Formation. (ES, Enforcement Standard; BAAP; Badger Army Ammunition Plant) 


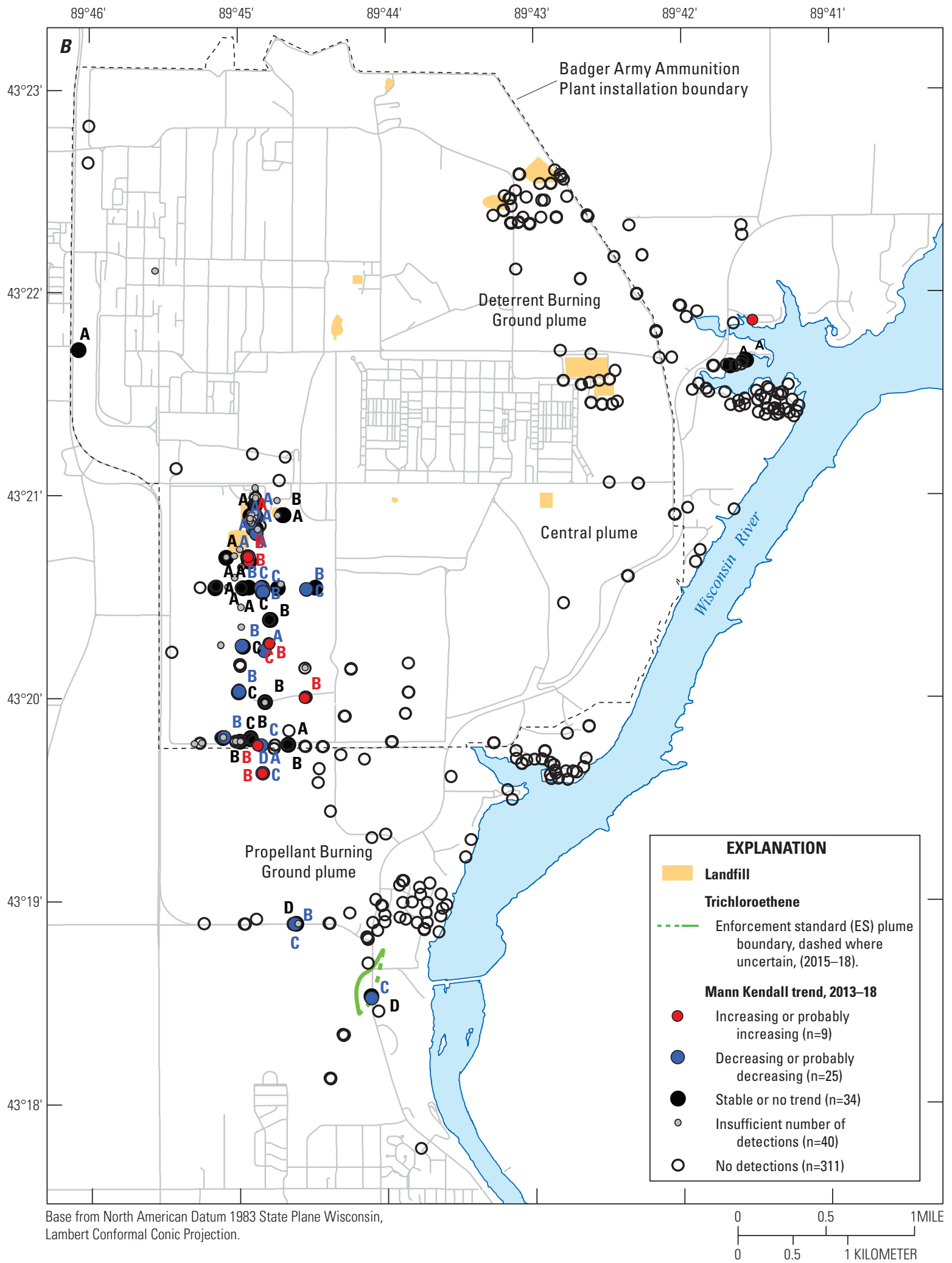

Figure 8.-Continued 


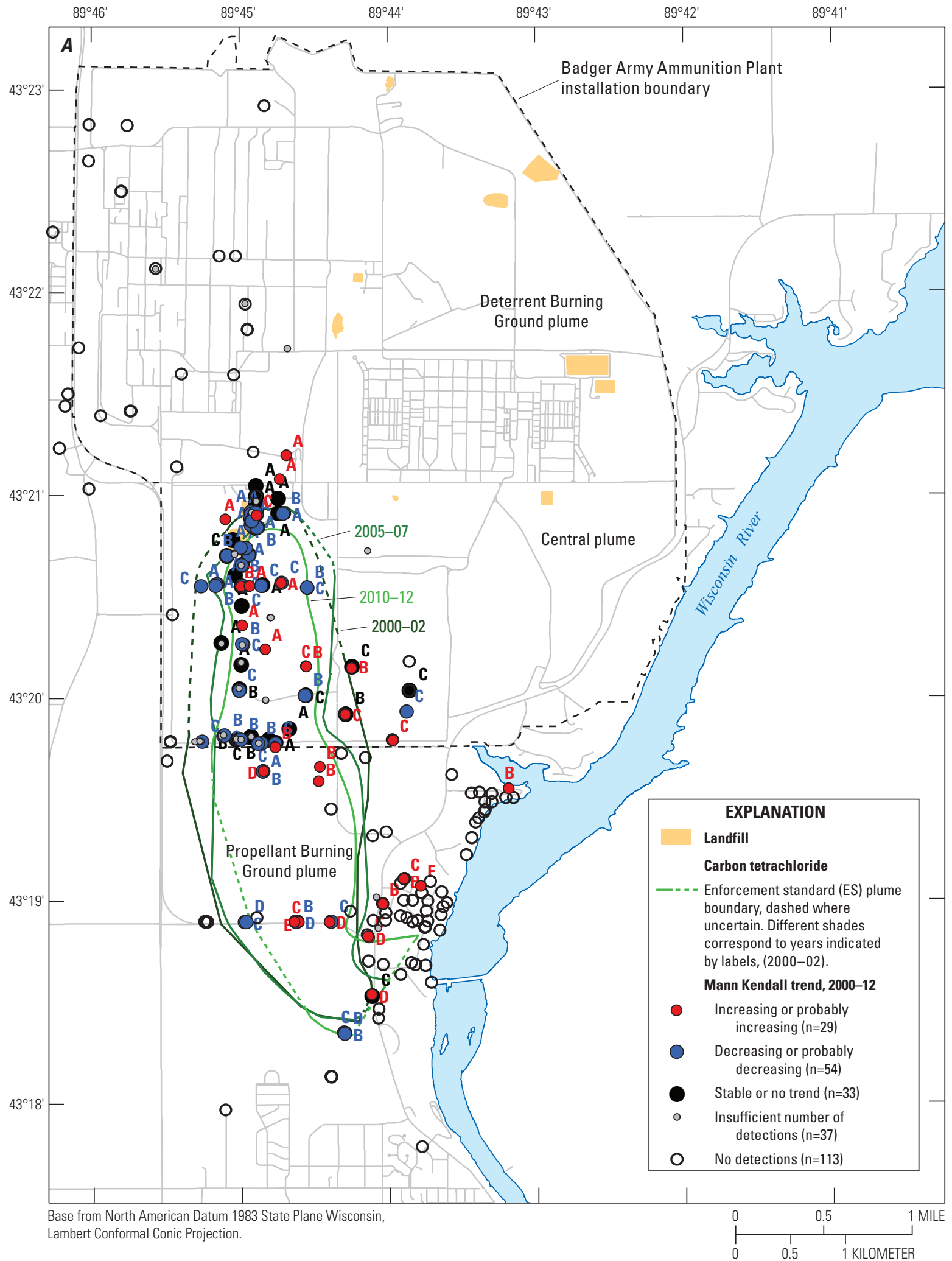

Figure 9. Map showing carbon tetrachloride plume delineations and concentration trends, Badger Army Ammunition Plant, for $A$, 2000-12 and B, 2013-18. (CTET, carbon tetrachloride; $\mathrm{A}$, well screen opening near the water table; $\mathrm{B}$, well screen opening one-third from the water table to bedrock; $C$, well screen opening two-thirds from the water table to bedrock; D, well screen opening just above bedrock; E, well opening in the Eau Claire Formation. (ES, Enforcement Standard; BAAP; Badger Army Ammunition Plant) 


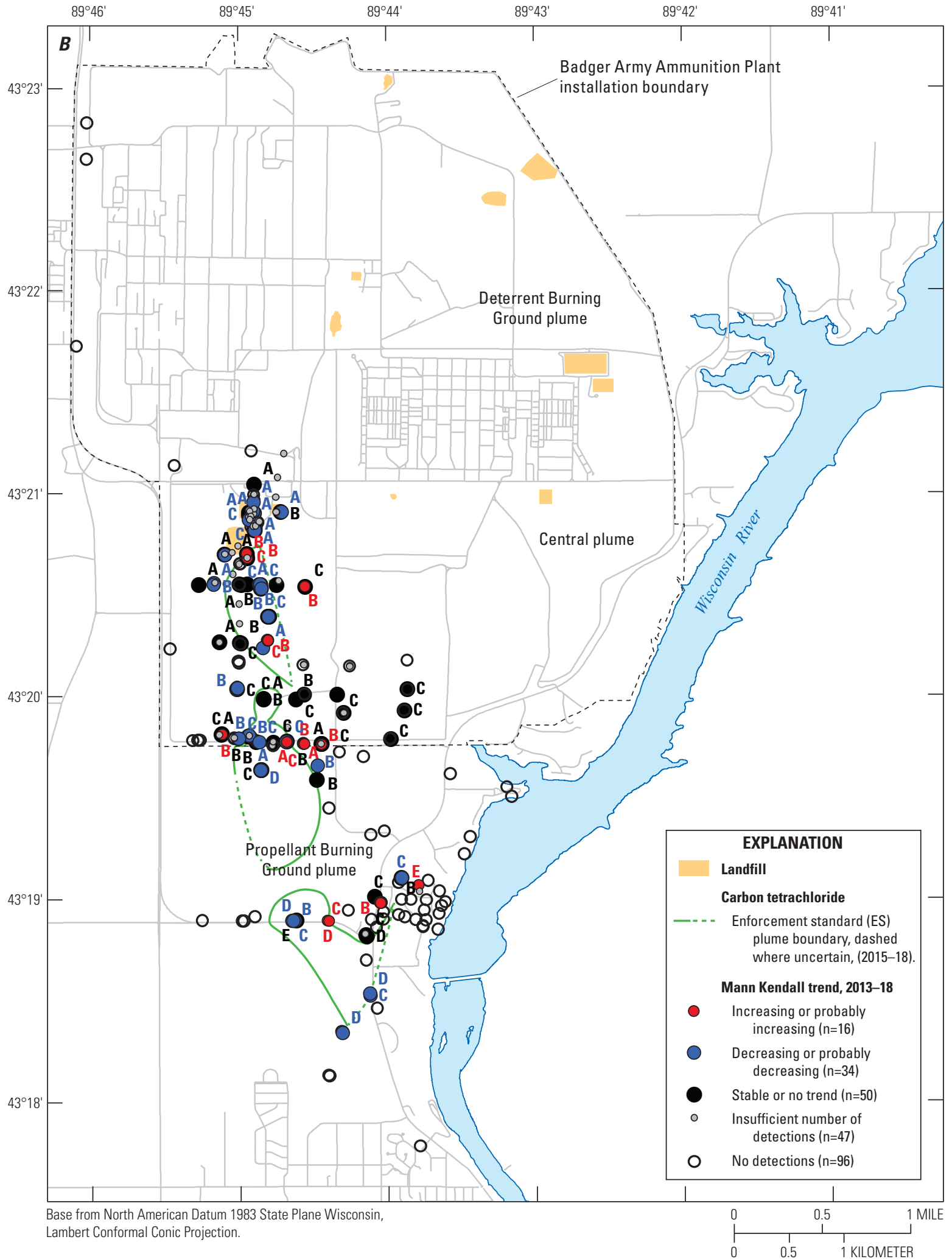

Figure 9.-Continued 


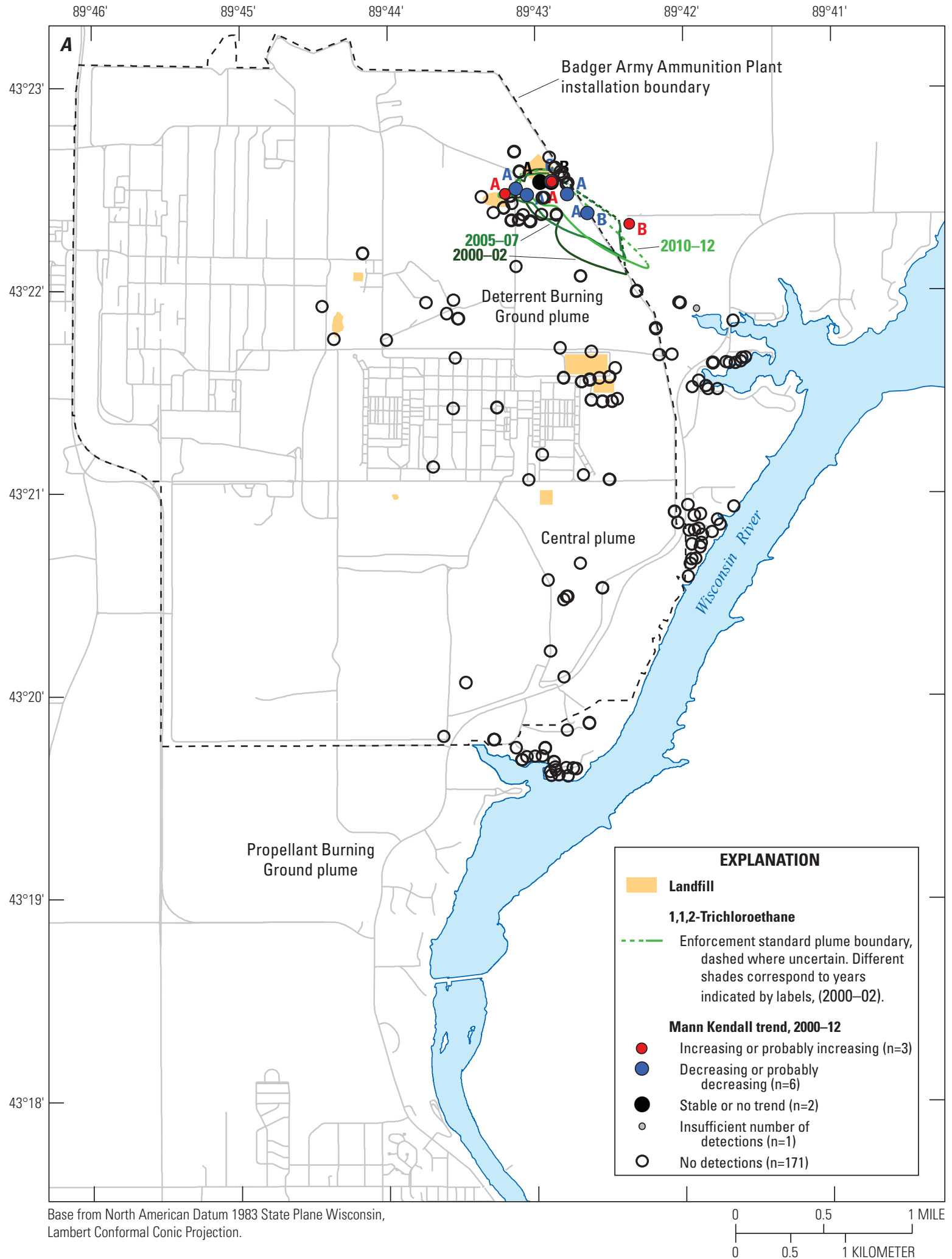

Figure 10. Map showing 1,1,2-trichloroethane plume delineations and concentration trends, Badger Army Ammunition Plant, for $A, 2000-12$ and $B, 2013-18$. (1,1,2-TCA, 1,1,2-trichloroethane; A, well screen opening near the water table; $B$, well screen opening one-third from the water table to bedrock; $C$, well screen opening two-thirds from the water table to bedrock; D, well screen opening just above bedrock; E, well opening in the Eau Claire Formation. (PAL, Preventive Action Limit; BAAP; Badger Army Ammunition Plant) 


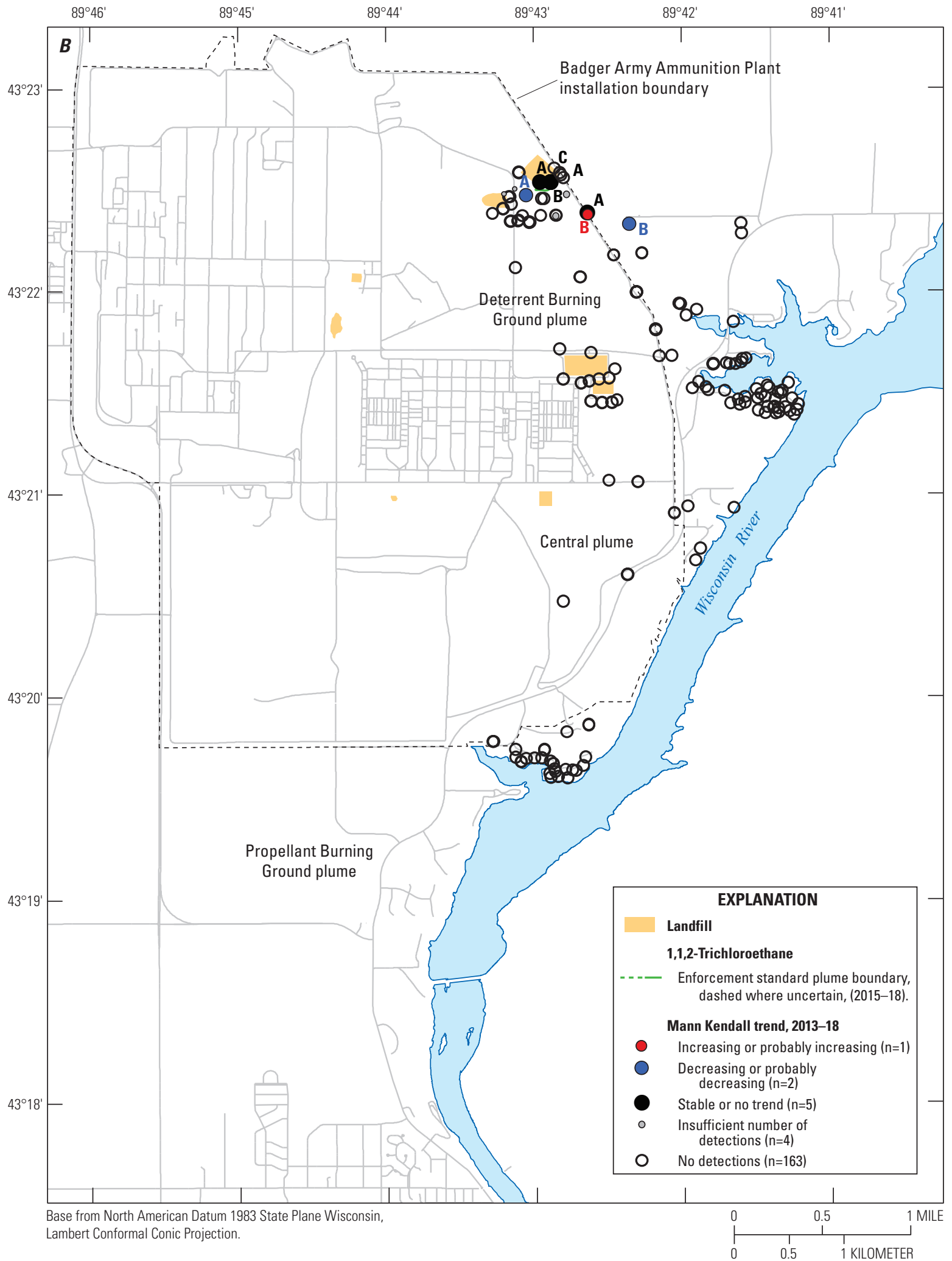

Figure 10.-Continued 


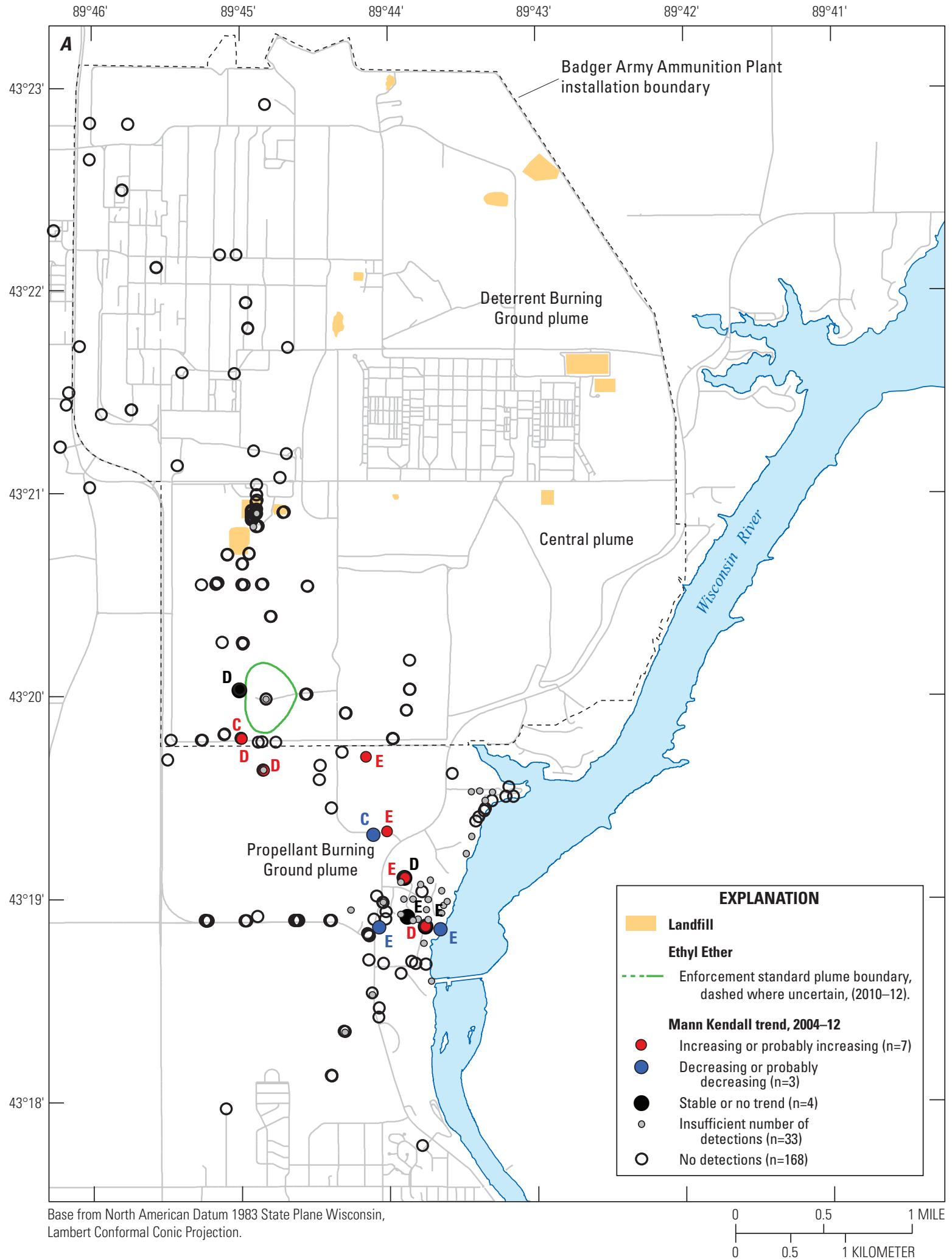

Figure 11. Map showing ethyl ether plume delineations and concentration trends, Badger Army Ammunition Plant, for $A$, 2004-12 and $B$, 2013-18. (A, well screen opening near the water table; $B$, well screen opening one-third from the water table to bedrock; $C$, well screen opening two-thirds from the water table to bedrock; $D$, well screen opening just above bedrock; E, well opening in the Eau Claire Formation. (ES, Enforcement Standard; BAAP; Badger Army Ammunition Plant) 


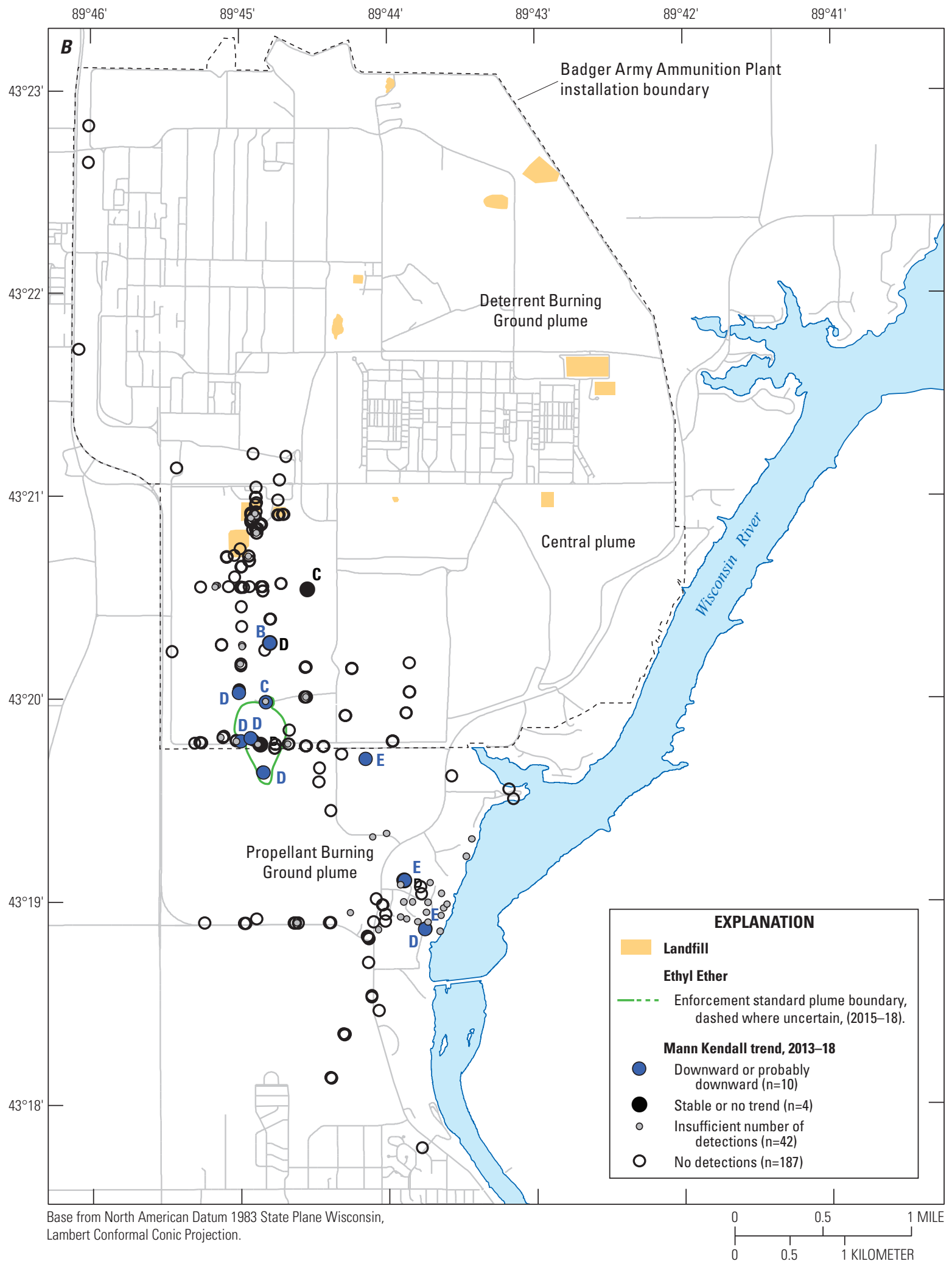

Figure 11.-Continued 


\section{Propellant Burning Ground Plume}

Trend analyses for the PBG plume were completed for six COCs for 2000-12 and 2013-18. Total DNT was analyzed only in the 2013-18 period (tables 8-13). Data for total DNT were not reported before 2011. For 2000-12, the mass of the plume for each COC (the zeroth moment) was decreasing, stable, or no trend was detected across all depth intervals, with the exception of CTET in the D level, which was increasing in mass (table 12). For 2013-18, there are fewer plume trend analyses because more wells had either non-detects, precluding them from the analysis, or were not sampled. Results of the analyses were classified into four categories on the basis of change in plume mass: decreasing, probably decreasing, stable, or no trend. No COCs had an increasing trend in plume mass in 2013-18 (tables 8-13).

For total DNT, insufficient data were available to perform plume analysis in the PBG for any depth interval in the period 2000-12 (table 8, fig. 5A). Fourteen of 140 wells at various depth levels did have a sufficient number of COC detections to allow analysis of trends in individual wells. Trend analysis revealed that no wells were increasing in concentration, 6 wells were stable, 2 had decreasing concentrations, and 6 had no trend. During 2013-18, the trends for mass and the size of the total DNT plume were either stable, probably decreasing, decreasing, or no trend for those depth intervals where an analysis could be completed (fig. 5B). Trends for individual wells were consistent with the plume analysis; 21 wells had either stable, decreasing, or probably decreasing concentration trends and 4 wells had increasing or probably increasing concentration trends. A total of 14 wells had a result of no trend. The wells with increasing trends were in the A-depth interval and located near the source area (fig. 5).

Results for 2,4-DNT are similar to those for total DNT (table 9, fig. 6). The trend for mass of the contaminant was decreasing for the first time period in the depth intervals for which sufficient data were available. The trend for size of the plume was stable or had a result of no trend where enough data were available to identify a trend, except for the width of the plume in the $\mathrm{C}$ interval, which was increasing. For the 2013-18 period, the mass of 2,4-DNT was stable at the A depth interval, the only depth at which a plume analysis could be performed. Trends in individual wells varied, although more wells showed a decreasing trend than increasing trend for both the 2000-12 and 2013-18 time periods. In 2013-18, only one well (in the A interval) had an increasing trend (fig. 6B).

For 2,6-DNT, the trend for plume mass was decreasing in the first time period and stable in the period from 2013-18 (table 10, fig. 7). However, the distance from the source was increasing during the 2000-12 period at some depth intervals, as was the length and width. During the later time period, the mass and size were generally stable, with only the width showing an increasing trend in the $\mathrm{C}$ interval.

For TCE, the plume mass was decreasing, but the spread of the plume was generally increasing during the 2000-12 period (table 11, fig. 8). In the period from 2013 to 2018, the mass was still decreasing, and the spread was either stable or decreasing.
The plume analysis is consistent with individual well trends. During the 2013-18 period, 24 wells had stable trends, 25 had decreasing or probably decreasing trends, 8 had increasing or probably increasing trends, and 8 had no trend. The wells with increasing trends are near the source area; one well is just south of the BAAP boundary (fig. 8).

For CTET in the 2000-12 period, the spread of the plume was increasing across all depth intervals, but the mass was decreasing in depth intervals A-C and increasing in the D interval (table 12, fig. 9A). During the 2013-18 period, the plume was generally stable or decreasing in mass and size, except for a probable increase in distance from the source to the center of mass in the A interval (table 12, fig. 9B). Individual concentration trends are consistent with the plume analyses, with more decreasing or stable trends than increasing concentration trends in the 2013-18 time period.

For ethyl ether, plume trends could be calculated only for the E interval for 2000-12 and for the D interval for 2013-18; data were insufficient for all other depth intervals (table 13, fig. 11). During 2000-12 time period, the plume had no trend in mass or distance from the center of mass to the source, was stable in width, and increasing in length. In 2013-18, the mass and lateral extent of the plume were both decreasing. No wells showed an increasing trend in ethyl ether concentrations in the 2013-18 time period.

\section{Central Plume}

Plume analyses could not be conducted for the Central plume for any of the COCs for either the 2000-12 or 2013-18 periods owing to an insufficient number of wells with detections (tables 14-16). Trend analyses for DNT, 2,4-DNT and 2,6-DNT were conducted on a relatively small number of wells that were monitored. Results of trend analyses were either stable, no trend, probably decreasing, or decreasing for each $\mathrm{COC}$ during 2000-12 and 2013-18 (tables 14-16). For 2,4-DNT, concentration trends in individual wells were stable in the 2 wells in which a trend could be determined for 2000-12 and either stable or decreasing in the 3 wells during 2013-18 (table 15, fig. 6). For 2,6-DNT, trends for wells were stable, decreasing, or no trend in concentration for the first time period (table 16, fig. 7A). During the 2013-18, trends in 3 individual wells were stable, and 6 wells showed no trend in concentration (fig. 7B). Individual well trend analysis could not be conducted for TCE owing to an insufficient number of detections, and 1,1,2-TCA was not detected in any wells within the Central plume.

\section{Deterrent Burning Ground Plume}

Only the A depth interval contained enough wells with detections to conduct a plume analysis for the DBG but not for every COC or time period. No plume analysis could be conducted for TCE in either 2000-12 or 2013-18. For other COCs, plume analyses revealed mixed trends. The individual well trend analyses also reflect a range from increasing to decreasing trends in concentration for all COCs (tables 17-21). 


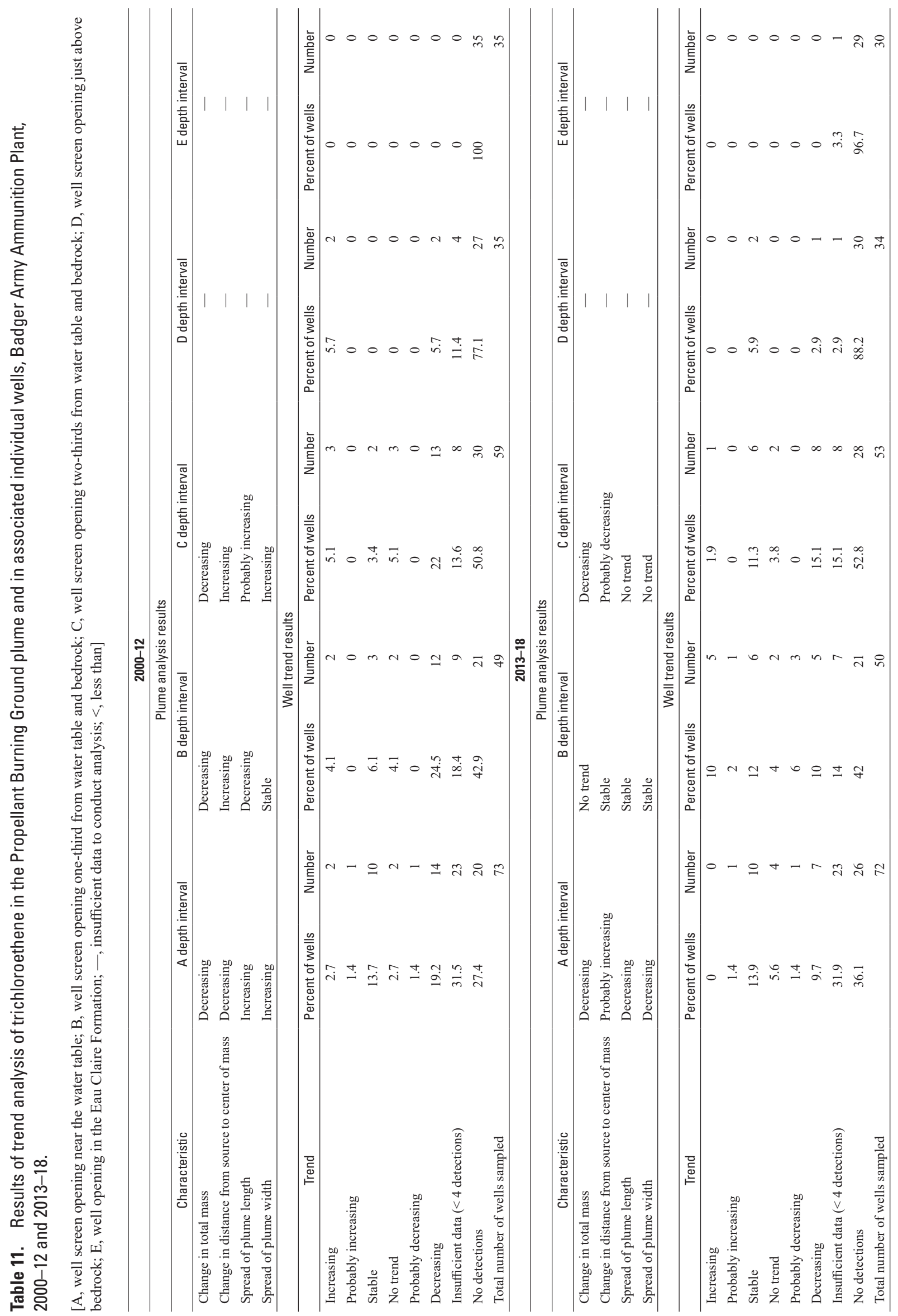




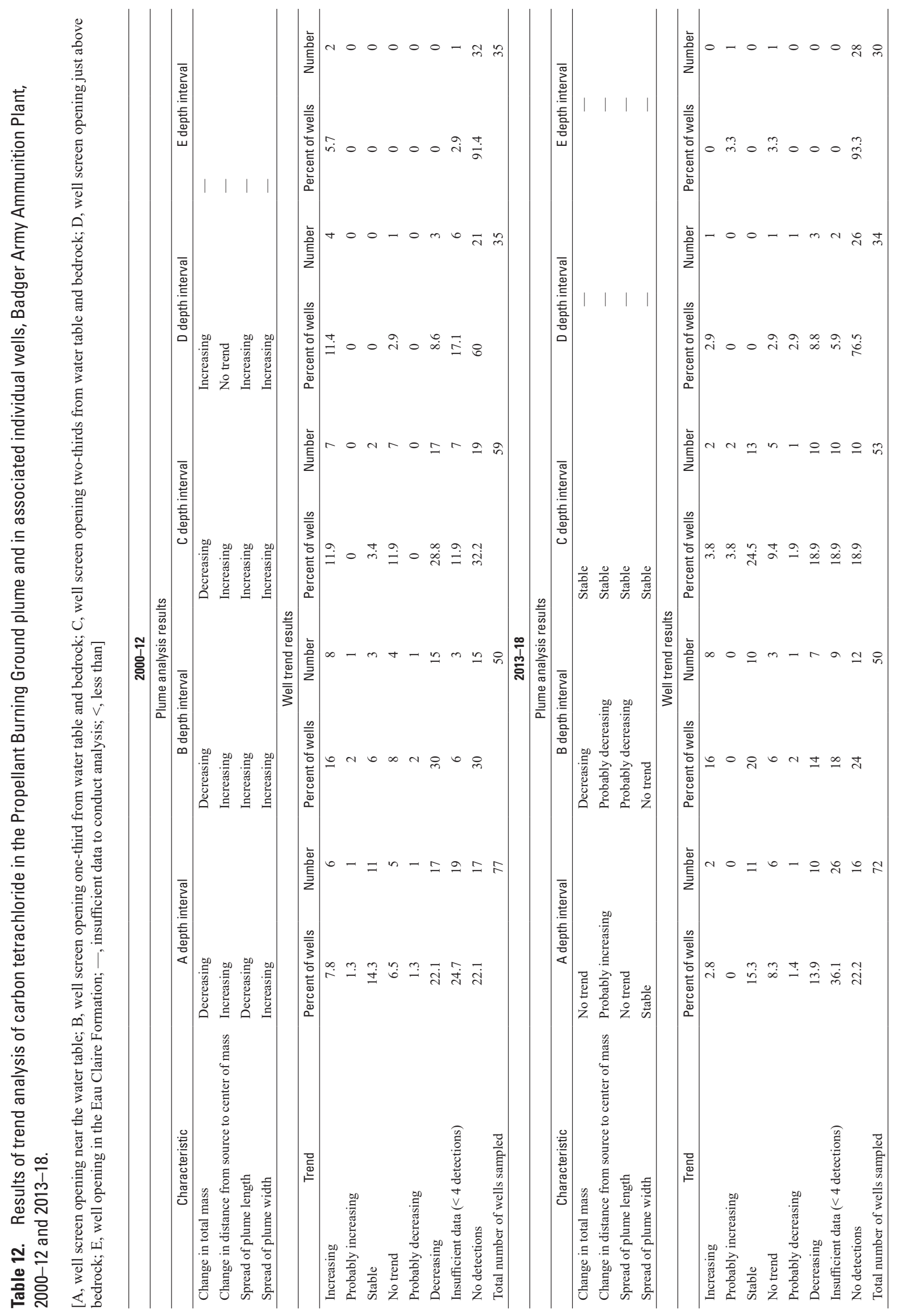




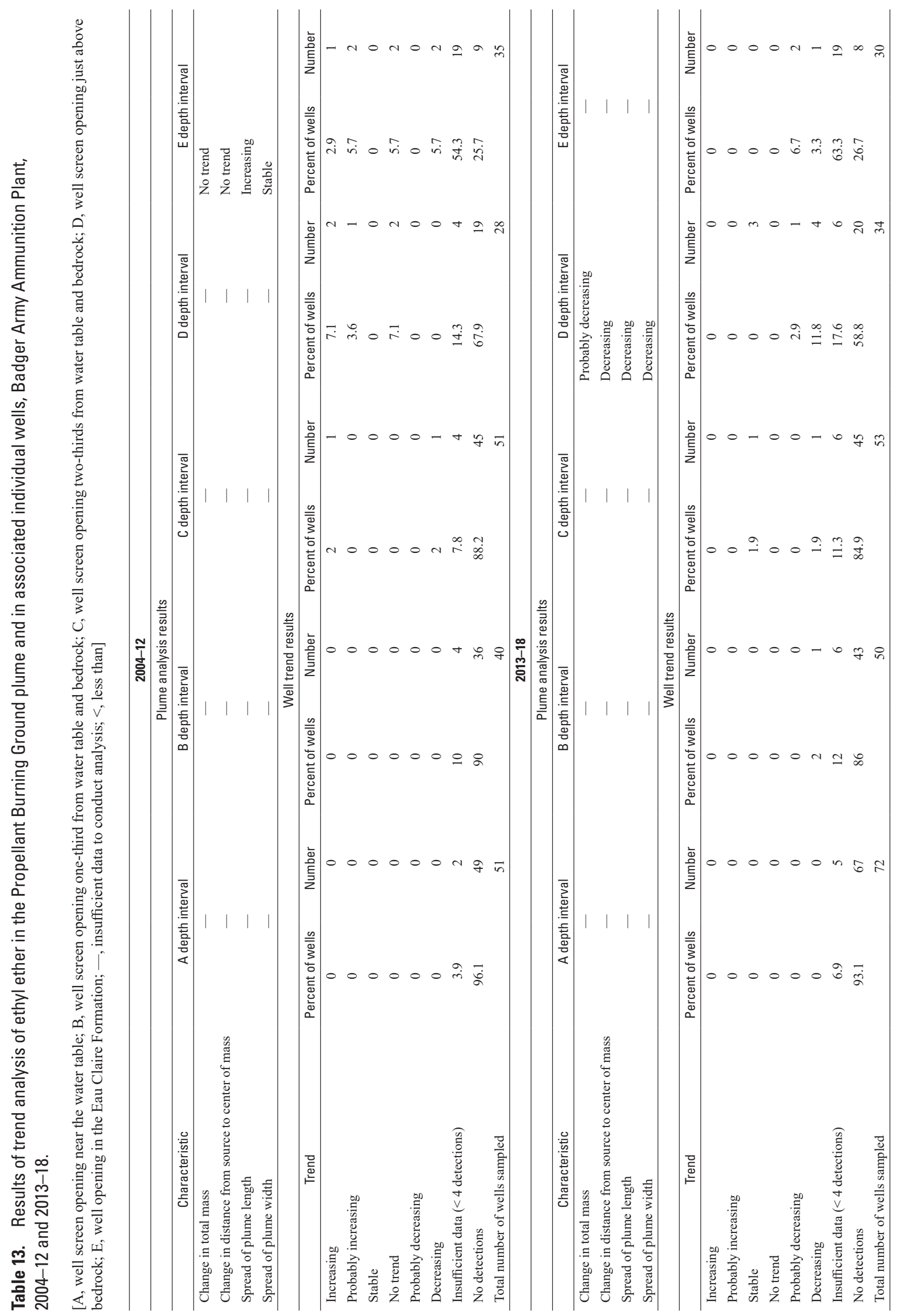




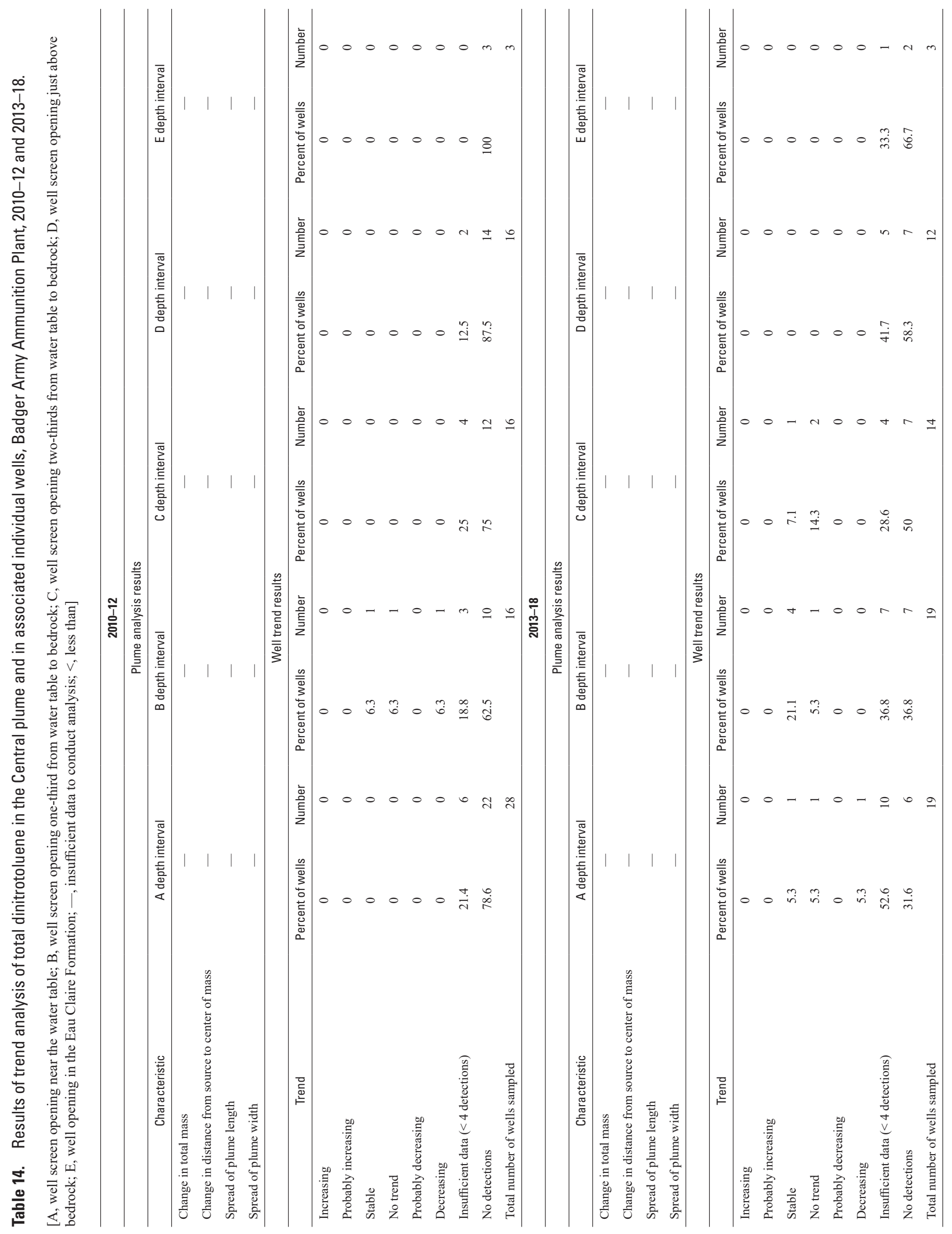




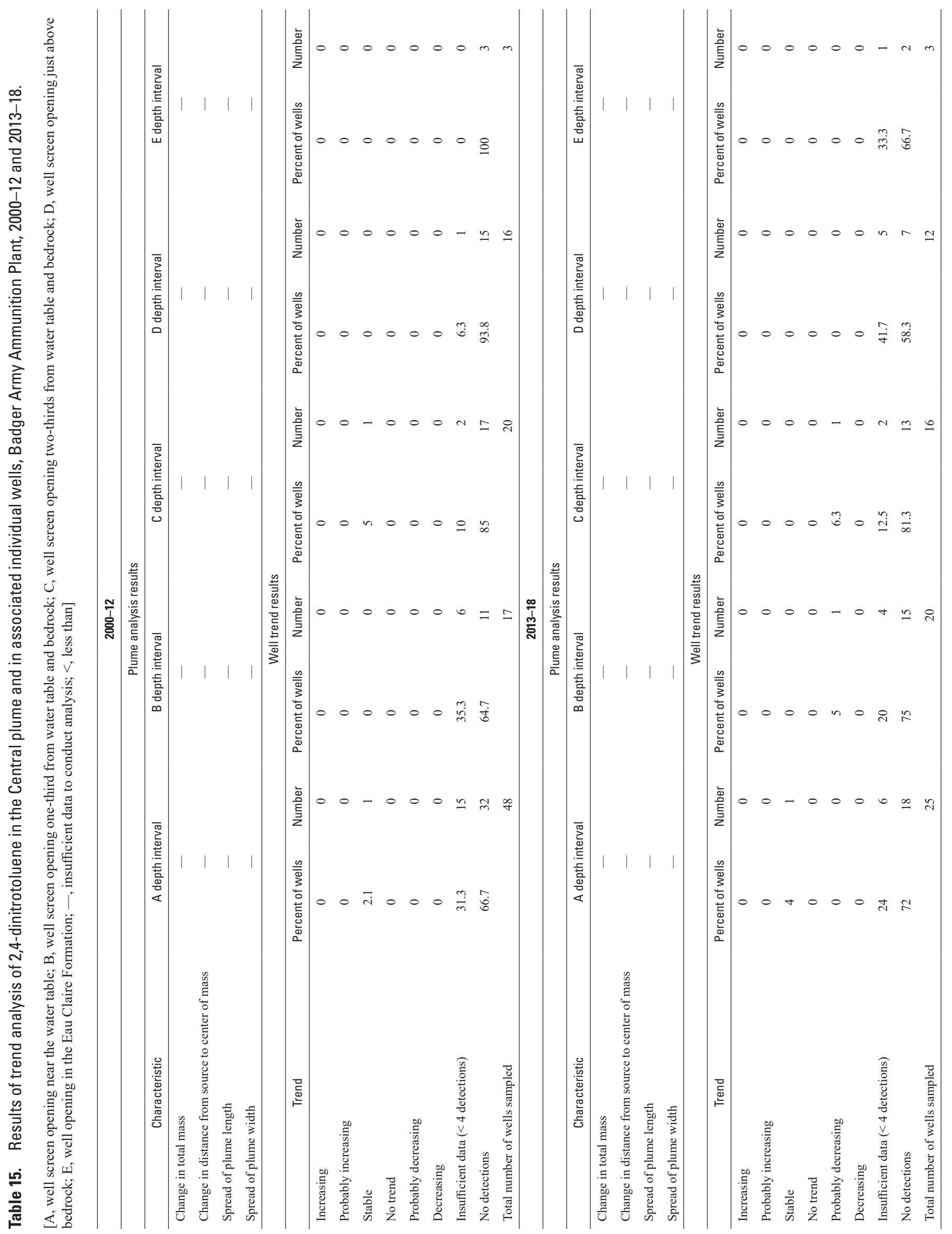




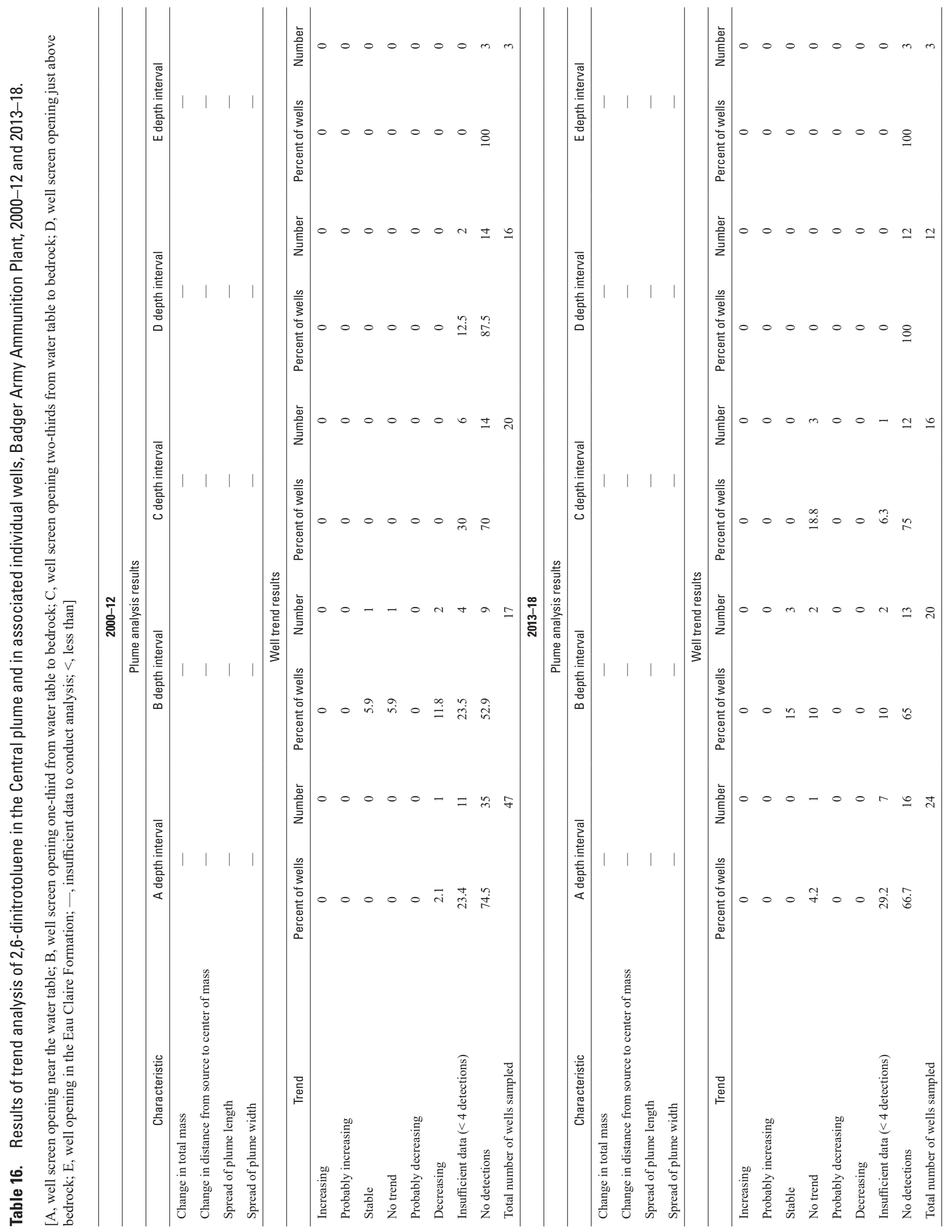




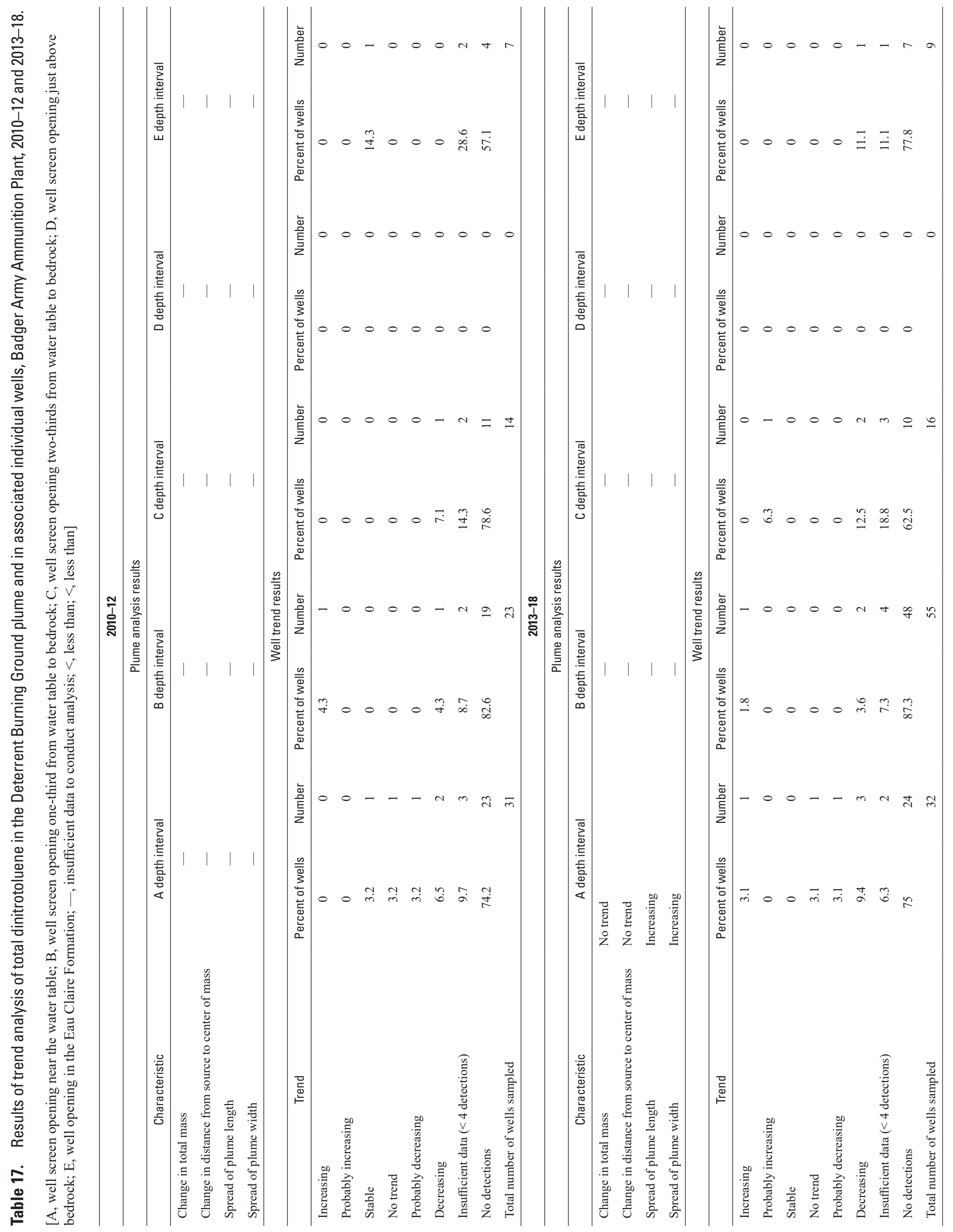




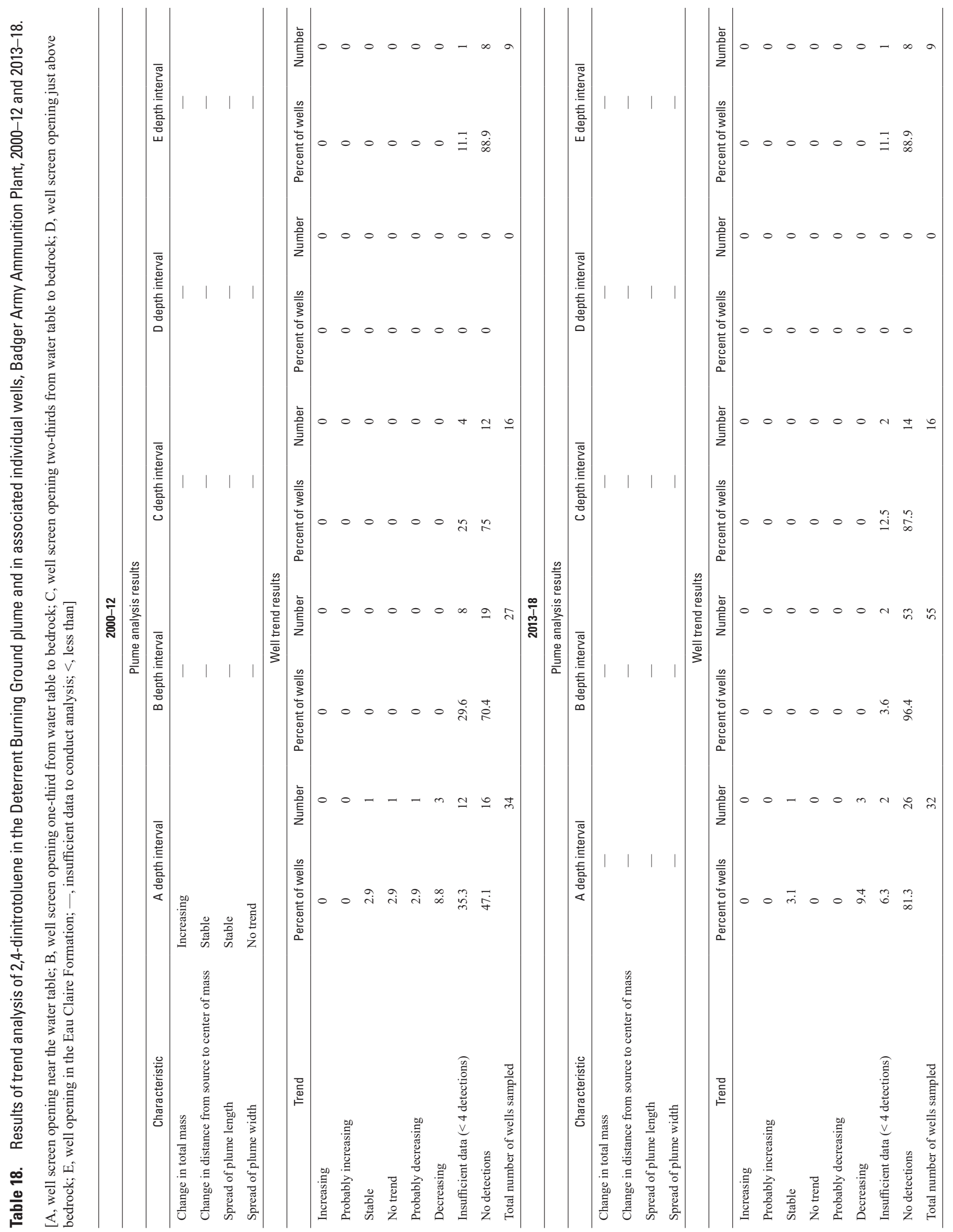




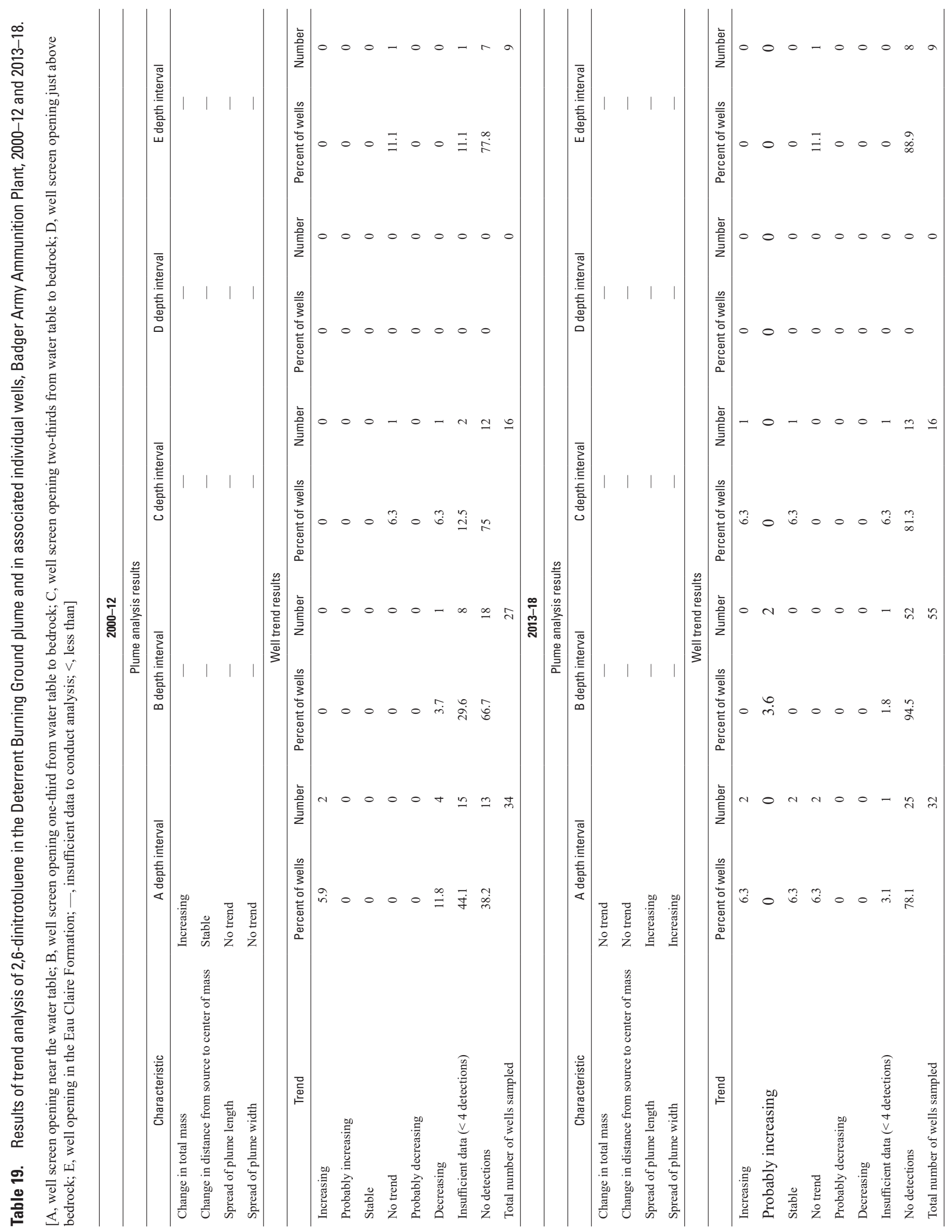




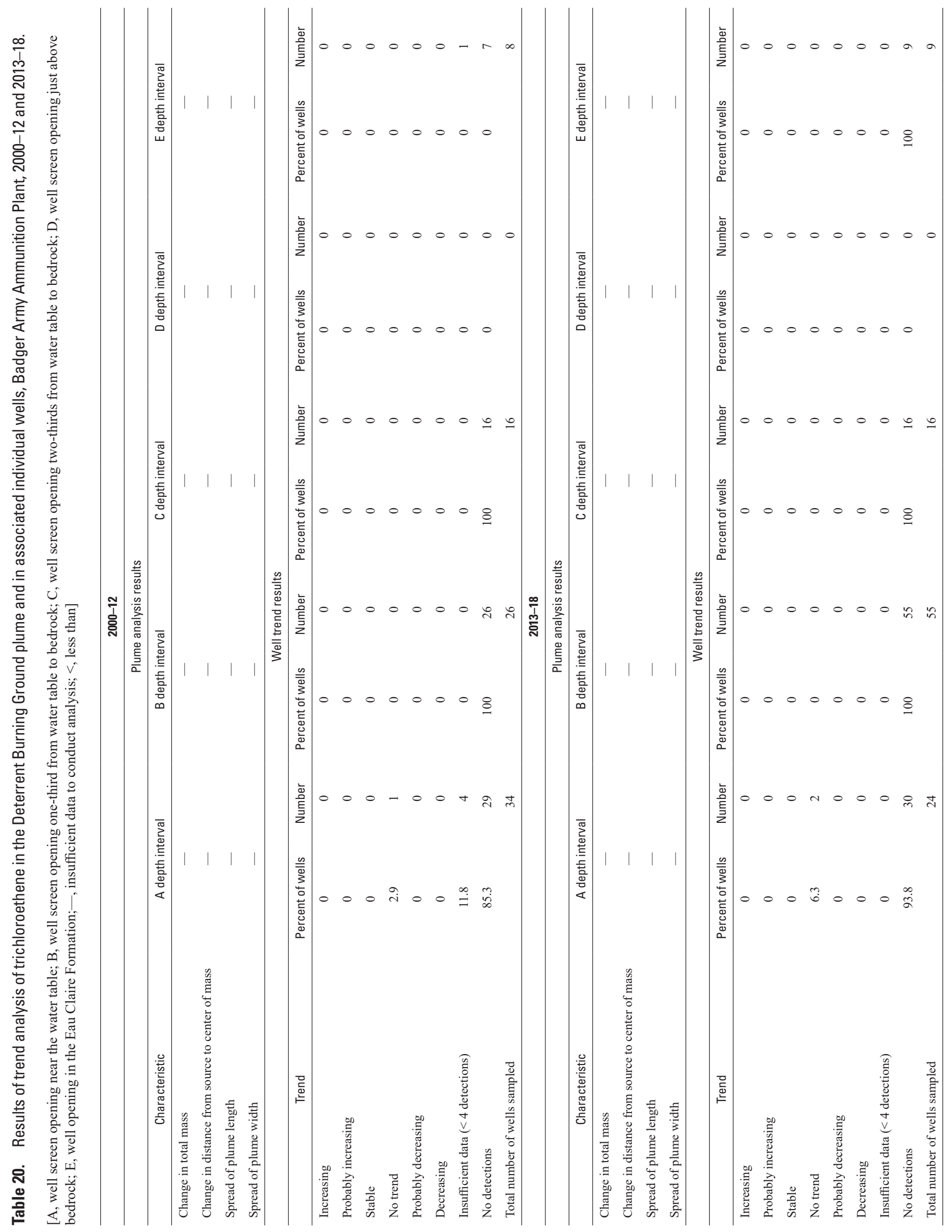




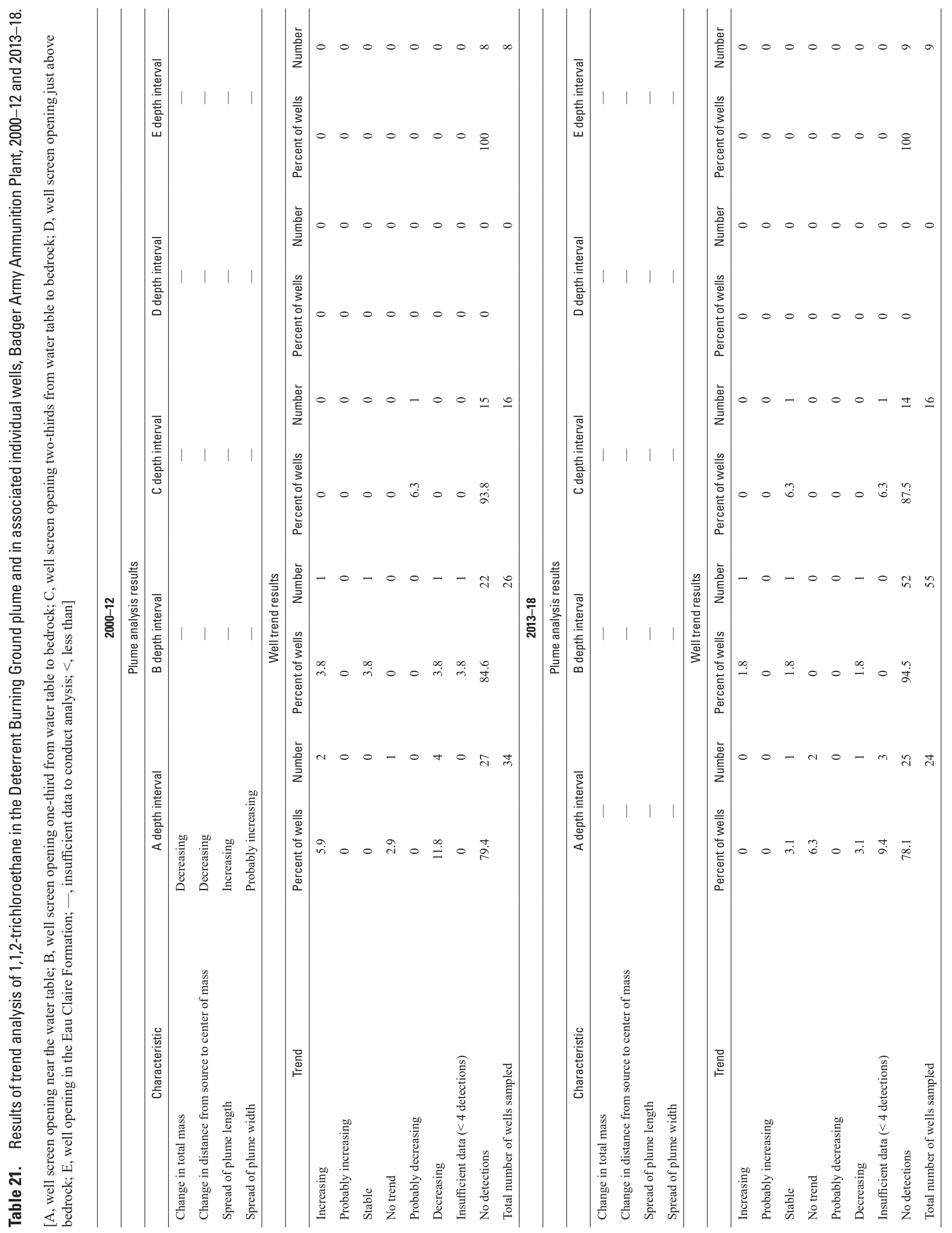


A plume analysis for total DNT could be completed only in the A interval for 2013-18. The analysis revealed no trend in mass or distance from the source to the center of mass, but showed an increasing trend in the length and width of the plume (table 17, fig. 5A). For both time periods, more well trends were decreasing than increasing in concentration. However, the location of the wells with increasing trends at the tail of the plume is important (fig. 5A, B).

For 2,4-DNT, the A interval was analyzed for a plume trend in 2000-12, which revealed a trend of increasing mass (table 18, fig. 6A). However, no individual wells had an increasing trend for this $\mathrm{COC}$ in either time period (fig. 6A, B).

For 2,6-DNT data were sufficient for plume analyses in both time periods for the A interval (table 19). The plume mass was increasing for the 2000-12 period, but no trend for mass or distance to source was identified for 2013-18. Individual well trend analysis showed two A-interval wells had increasing concentrations for both time periods, and three wells had increasing or probably increasing concentrations in the later time period in the $\mathrm{B}$ and $\mathrm{C}$ intervals. Two of the wells with increasing concentrations are the same two as at the plume tail that showed an increasing trend in total DNT (fig. 7).

For 1,1,2-TCA during 2000-12, A-interval wells showed a decreasing trend in mass and distance to the source but an increase in plume length and width (table 21). For the same time period, most individual wells for which a trend analysis could be conducted were decreasing or probably decreasing in concentration. No plume trend analysis could be conducted for the 2013-18 period, during which one well was increasing, three were stable, two had no trend, and two were decreasing in concentration (fig. 10).

\section{Individual Well Remediation Status}

The remediation status of individual wells was evaluated by comparing the mean COC concentration to the target remediation level (ES). A modified, sequential t-test and power analysis were used to determine the statistical significance of the comparison. If the t-test showed that the mean concentration was less than the ES, the power analysis was used to evaluate the strength of the t-test by considering the variability around the mean. If the power analysis indicated a large variability around the mean, the well resulted in a status of less than the ES but not with statistical significance. The remediation status was evaluated for each COC separately, so an individual well may have a different status relative to each COC. Statistical analysis of remediation status was evaluated for a COC only if the minimum number of detections (generally four) was available. A total of 238 wells with at least one COC detection during 2000-12 or 2013-18 were evaluated, and the mean COC concentration was assessed according to the following remediation status categories (fig. 12):

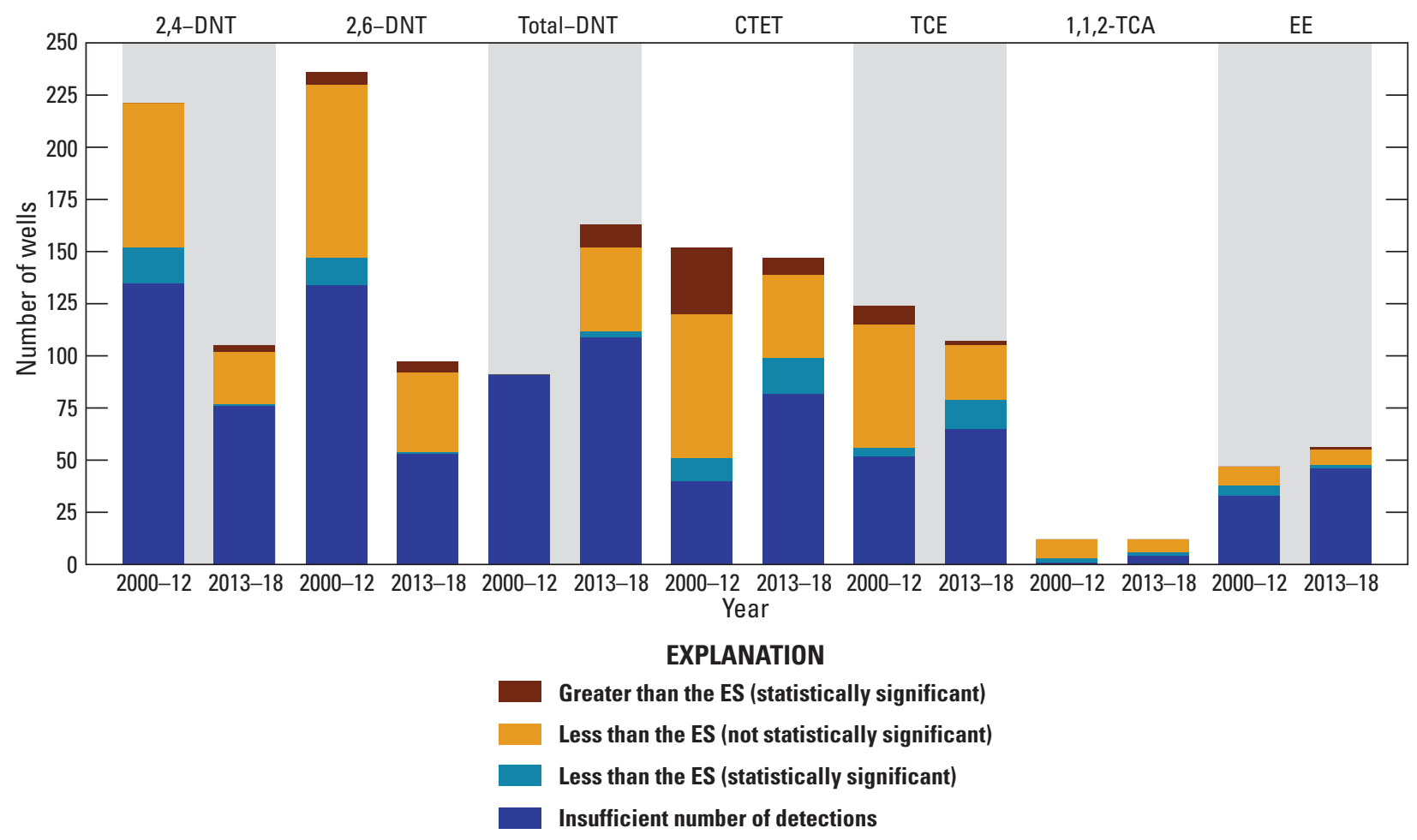

Figure 12. Summary of well remediation status by Enforcement Standard for each contaminant of concern, Badger Army Ammunition Plant, 2000-12 and 2013-18. (ES, Enforcement Standard; DNT, dinitrotoluene; CTET, carbon tetrachloride; TCE, trichloroethene; TCA, trichloroethane; EE, ethyl ether) 
1. Greater than the ES (statistically significant),

2. Less than the ES (not statistically significant),

3. Less than the ES (statistically significant), and

4. Insufficient number of detections.

For all of the COCs, the most frequent status was less than the ES, not statistically significant. Sixty-one wells had attained remediation (less than the ES, statistically significant) for one or more COCs, but none of the 238 wells had attained remediation (less than the ES, statistically significant) for all COCs that were relevant to that well.

For total DNT, insufficient data were available in the 2000-12 period to analyze cleanup status. In the 2013-18 period, 11 wells had concentrations greater than the ES, and 3 had concentrations significantly less (fig. 13). For 2,4-DNT and 2,6-DNT, more wells had concentrations less than the ES than greater than the ES in 2000-12. That relation reversed in the 2013-18 period, but note that the total number of wells that could be evaluated for cleanup status declined substantially because wells that had decreased concentrations either were no longer sampled or no longer had a sufficient number of detections to perform the analysis (figs. 12, 14, 15). The wells with concentrations that exceeded the ES for any DNT contaminant generally were in the source area of the PBG and DBG plumes, except for one well with total DNT in the C interval near the tail of the PBG plume (fig. 13B).

For TCE and CTET, the number of wells with concentrations greater than the ES decreased, and the number with less than the ES increased in 2013-18 (fig. 12). For both contaminants, some wells near the tail of the PBG plume had concentrations that remained greater than the ES in the later time period (figs. 16, 17). By contrast, ethyl ether had one additional well with concentrations greater than the ES in 2013-18, whereas the number of wells that had attained the cleanup status was reduced from 5 to 2 . A single well near the edge of the BAAP installation boundary had not attained cleanup status during 2013-18 (fig. 18B). For 1,1,2-TCA, no wells had concentrations significantly greater than the ES in either time period (fig. 19).

\section{Comparison of Plume Boundary Delineations with Results of Statistical Analyses}

The results of statistical analyses of plume and well trends for a given contaminant generally were consistent with the plume delineations over time, when data were sufficient to complete both sets of analyses. There were some exceptions.

For 2,4-DNT, the plume boundary delineations show a general decrease in plume size over time in the PBG and DBG plumes (plates 3 and 13). The plume statistical analysis confirmed a decreasing trend in mass in the PBG during 2000-12, which became stable by the 2013-18 period (table 9). In the Central plume, insufficient data were available for the plume statistical analysis for 2,4-DNT (table 15). No wells showed an increasing trend in concentration, which is consistent with the plume maps (plate 9). For the DBG, contaminant mass as represented by the zeroth moment was increasing in the early period in the A interval, contrary to the plume maps, but the Mann-Kendall test showed no individual wells with an increasing trend, and no wells had concentrations greater than the ES with statistical significance (table 18, fig. 14). This apparent inconsistency is related to a single well with two incidents of high concentrations in 2008, which drove the plume mass to increase. Concentrations in the same well decreased during 2015-18.

For 2,6-DNT, the plume extent in the PBG plume decreased over time, becoming stable by the 2015-18 period (plate 4), which is consistent with statistical analysis results for the plume mass, although the width and length of the plume increased during 2000-12 (table 10). Concentrations in wells at the tail end of the plume were greater than the PAL and showed an increasing trend, factors to consider when planning the location of new monitoring wells. In the DBG plume, the mass of 2,6-DNT was increasing in the A interval during 2000-12, which seems counter to a comparison of plume boundaries over the same period (table 19, plate 14). Statistical analysis of 2,6-DNT plume mass showed no trend for the 2013-18 period. Two wells in the C and D intervals near the tail of the plume had concentrations greater than the ES but were stable or showed no trend in concentration (fig. 15).

For total DNT, a lack of sample data prior to 2010 precluded the drawing of plumes or performing statistical analyses for the earlier period. For the PBG plume, boundary delineation maps show a stable plume from 2010 onward, and the plume statistical analysis showed a stable to decreasing mass (plate 5, table 8). However, several individual wells in the source area had an increasing trend in the 2013-18 time period (fig. 5B). In the Central plume, sparse detections resulted in a discontinuous plume map (plate 11). Statistical analysis showed no wells with an increasing trend, and none had concentrations greater than the ES with statistical significance (table 14, fig. 13A, B). In the DBG plume, the total DNT plume exhibits an increase in length between plume maps drawn for 2010-12 and 2015-18 (plate 15). However, statistical analysis showed no increase in plume mass (table 17). Statistical analysis showed three wells near the tail with increasing concentration trends (fig. 5B).

For TCE, there was one exceedance of the PAL in the Central plume and only for the $2000-02$ period (plate 7). For the PBG plume, the maps show a decreasing plume size, consistent with statistical analysis that showed decreasing plume mass (plate 1, table 11). During the 2013-18 period, plume length and width as measured by the second spatial moment were also decreasing. However, several wells near the source area had increasing concentrations, and concentrations of TCE in two wells near the plume tail exceeded the ES, although they were either stable or decreasing in concentration 
(figs. 8B, 16B). In the DBG plume, there were no exceedances of the ES; one well had increasing concentrations of TCE

(fig. 8, table 20).

Carbon tetrachloride was found only in the PBG plume, where the plume delineation maps show a decrease in size over time (plate 2). Results of statistical analysis show the plume mass was generally decreasing, except in the 2000-12 period when CTET mass was increasing in the D interval and in the 2013-18 period when it was probably increasing in the A interval (table 12). Concentrations in some wells near the tail were increasing (fig. 9); two wells near the tail had mean concentrations greater than the ES with statistical significance (fig. 17).

Ethyl ether was associated only with the PBG plume. Data were limited, but the plume maps show the plume was roughly the same size but shifting slightly south between the 2010-12 and the 2015-18 periods (plate 6). Results of statistical analyses show the plume decreasing in mass, length, and width in the later time period, and no wells with an increasing concentration trend (table 13). Wells with ethyl ether concentrations significantly greater than the ES are near the installation boundary (fig. 18).

The contaminant 1,1,2-TCA could be mapped only in the DBG plume. Plume maps show 1,1,2-TCA to be stable spanning 2000-12 (plate 16), when its mass was decreasing but length and width were increasing in the A-interval (table 21). The plume delineation decreased in size in the 2013-18 period, when no wells had concentrations exceeding the ES for 1,1,2-TCA, and data were insufficient to perform a plume statistical analysis (table 21). One well in the B interval had increasing concentrations (fig. 10B).

\section{Comparison of Trends to Past Remedial Actions}

The observed trends in individual wells and in the plumes were considered in relation to past remedial actions related to the PBG plume and the DBG plumes. Remedial actions were initiated at the PBG and DBG plumes prior to the year 2000, the first year for which data were used in this evaluation. Because this study did not look at trends prior to 2000, it is not possible to identify changes in trends that may or may not be attributable to the remedial actions. However, trends identified in both plumes after the year 2000 generally are consistent with results expected from the remedial actions undertaken prior to 2000 and through 2012.

Within the PBG plume, remedial actions initiated prior to 2000 included soil vapor extraction, partial excavation, capping, and a pilot-test of bioremediation. Such actions were intended to remove contaminants from the source area or to reduce their migration to groundwater by preventing the percolation of water through contaminated soils. In addition, the Interim Remedial Measure pump-and-treat system (IRM) was initiated in 1990, and the Modified Interim Remedial Measure (MIRM) was put into operation in 1996. These systems were intended to remove contaminants from groundwater. The IRM continued to operate through 2012. Additional extraction wells were added to the MIRM during 2005-06, and the MIRM extraction wells were shut down in 2015. A Biologically Enhanced Subsurface Treatment system operated from 2001 to 2005, which reduced the amount of DNT in groundwater (SpecPro Professional Services, 2018).

The plume boundary maps and statistical analysis of historical water-quality data completed for this study generally indicate a decreasing trend in the mass and size of the PBG plume from 2000 through 2012, during the time that the IRM and MIRM operated. Exceptions include CTET in the D interval from 2000 to 2012 when plume mass was increasing, and 2,4-DNT and 2,6-DNT plumes, which increased in size or distance to the source while decreasing in mass (tables 9, 10, 11). These areas are downgradient from the remedial measures and probably represent movement of contaminants that were outside the capture zone of the extraction wells. After 2012, the analyses indicate no increases in plume mass for any COC; however, CTET and TCE in the A interval probably increased in distance to source from 2013 to 2018, indicating some movement, and 2,6-DNT in the $\mathrm{C}$ interval increased in width (tables 11, 12). These changes are consistent with attenuation of contaminants related to migration and dilution.

Within the DBG plume, remediation efforts included soil removal prior to 2000. Partial excavation and capping were completed in 2003 (SpecPro Professional Services, 2018). An enhanced bioremediation system operated from 2003 through 2008 when it was abandoned owing to a lack of information supporting its effectiveness (U.S. Army Corps of Engineers, 2013).

During the 2000-12 period, the masses of 2,4-DNT and 2,6-DNT were increasing in the A interval, supporting the conclusion that the bioremediation system was not producing noticeable improvements (tables 18, 19). During the 2013-18 period, no trends in contaminant mass were detected; for total DNT and 2,6-DNT, the length and width of the DBG plume were found to be increasing in the A interval, indicating continued plume migration (tables 17, 19).

\section{Monitoring Network Optimization}

Wells in all three plumes were analyzed for optimal sampling frequency (temporal optimization) and for well redundancy and well sufficiency (spatial optimization). In addition to individual wells needing at least four detections per well to complete the individual well analyses, parts of the optimization analysis required as many as six wells with sufficient data. Therefore, not all wells with an individual trend or cleanup status were included in the optimization. 


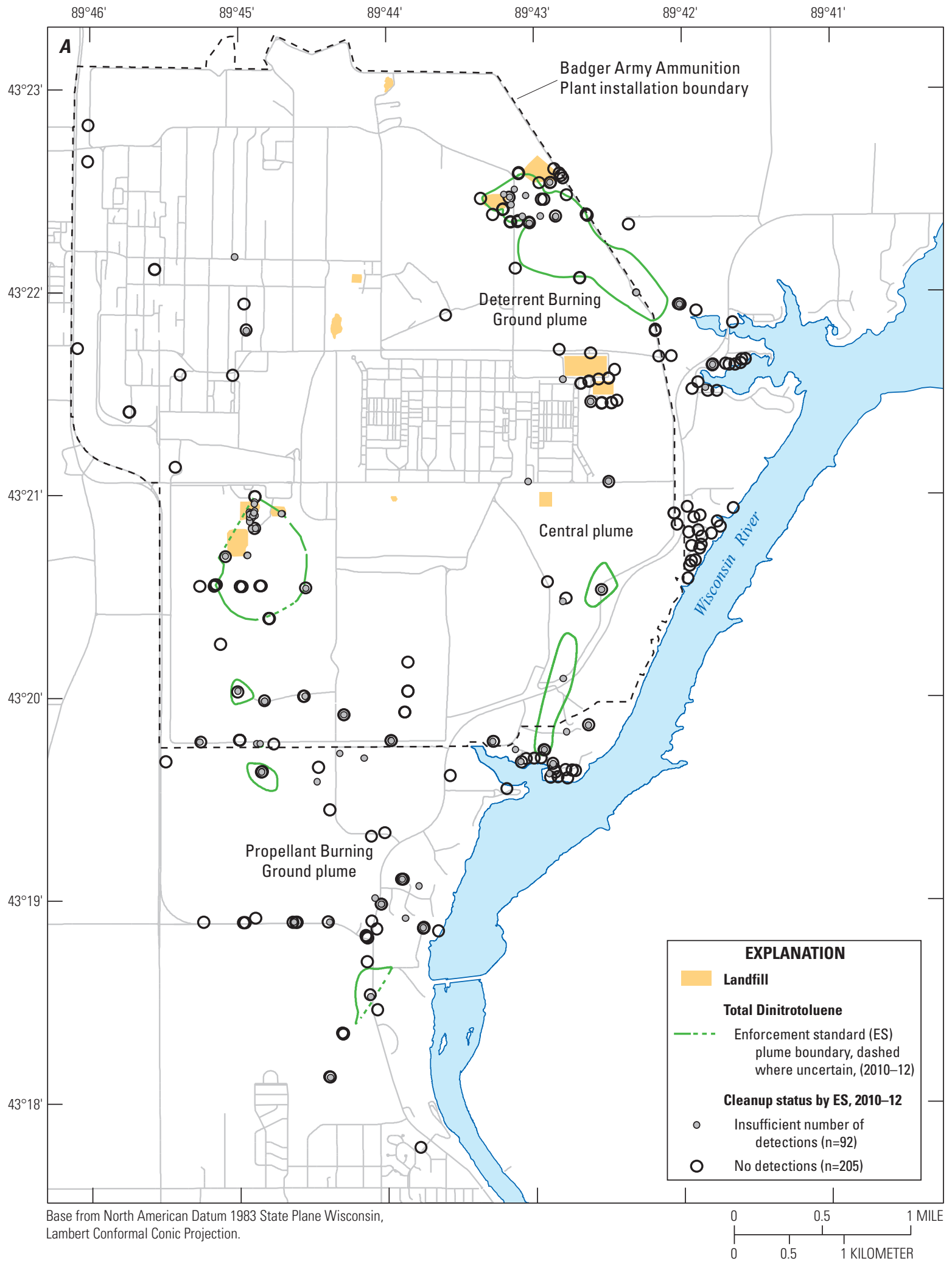

Figure 13. Map showing status of total dinitrotoluene remediation in monitoring wells relative to the Enforcement Standard, Badger Army Ammunition Plant, for A, 2010-12 and B, 2013-18. DNT, total dinitrotoluene. (ES, Enforcement Standard; $A$, well screen opening near the water table; $B$, well screen opening one-third from water table to bedrock; $C$, well screen opening two-thirds from water table to bedrock; $D$, well screen opening just above bedrock; $E$, well opening in the Eau Claire Formation) 


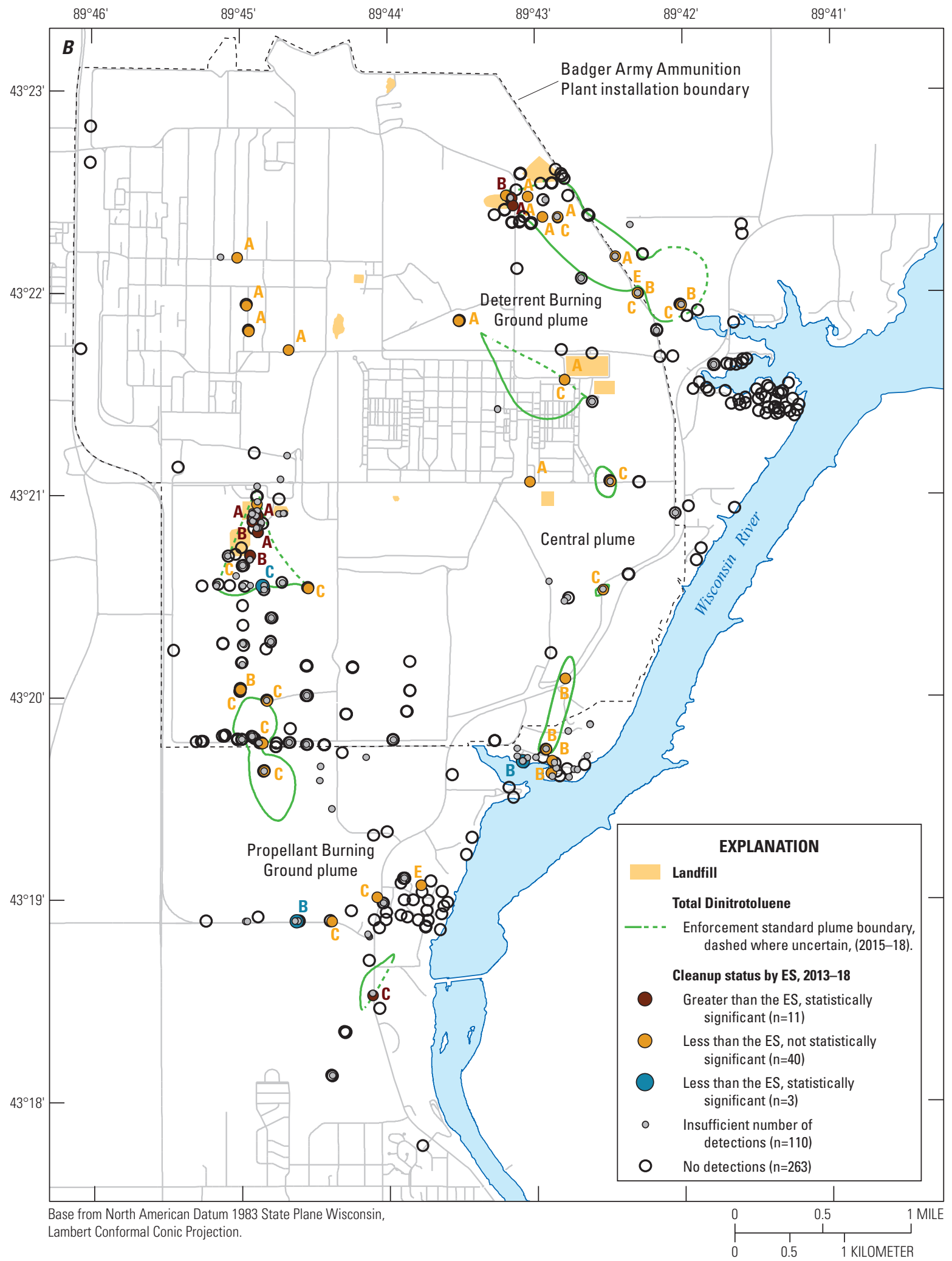

Figure 13.-Continued 


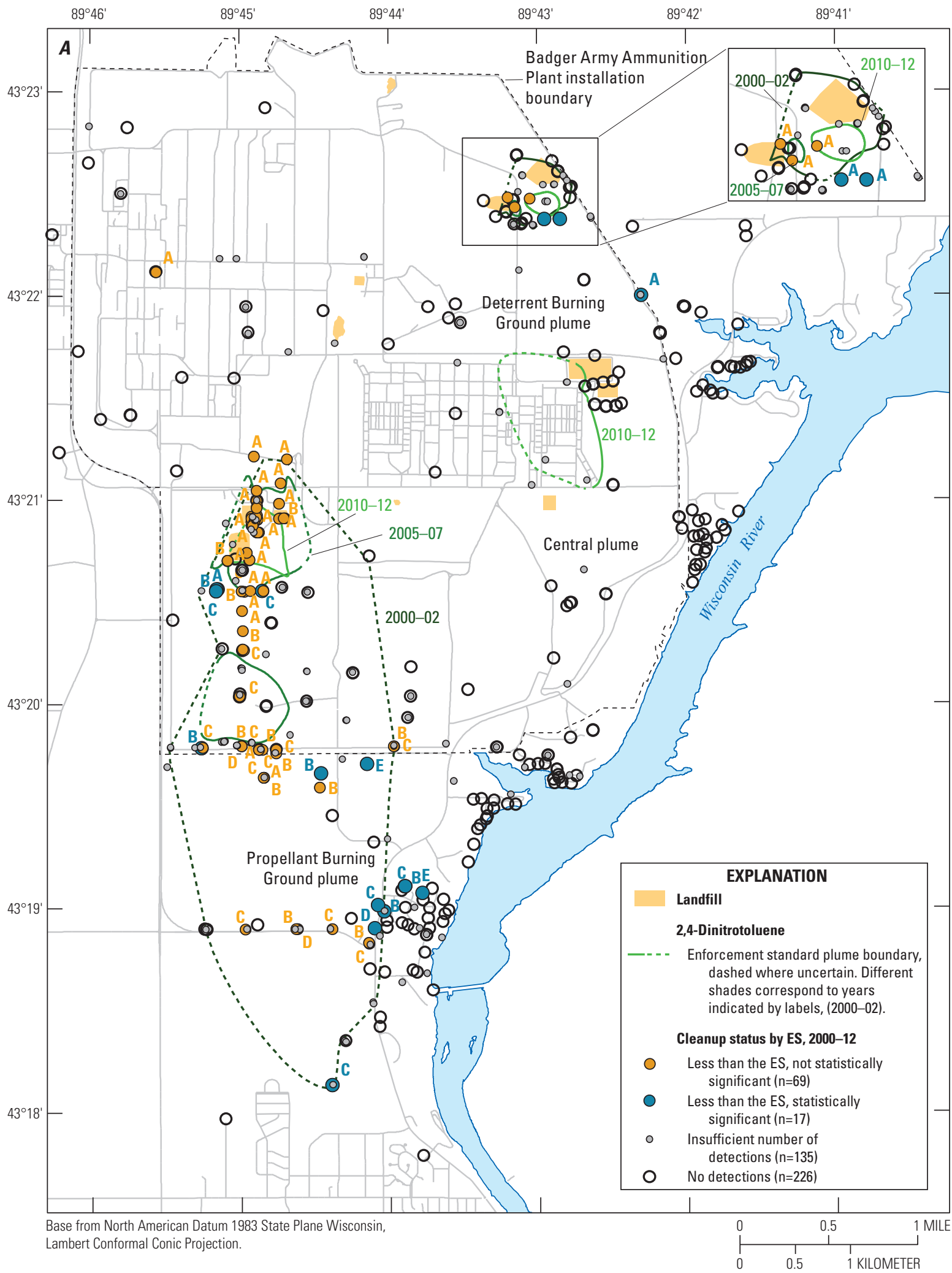

Figure 14. Map showing status of 2,4-dinitrotoluene remediation in monitoring wells relative to the Enforcement Standard, Badger Army Ammunition Plant for A, 2000-12 and B, 2013-18. (2,4-DNT, 2,4-dinitrotoluene; ES, Enforcement Standard; $A$, well screen opening near the water table; $B$, well screen opening one-third from water table to bedrock; $C$, well screen opening two-thirds from water table to bedrock; D, well screen opening just above bedrock; $E$, well opening in the Eau Claire Formation) 


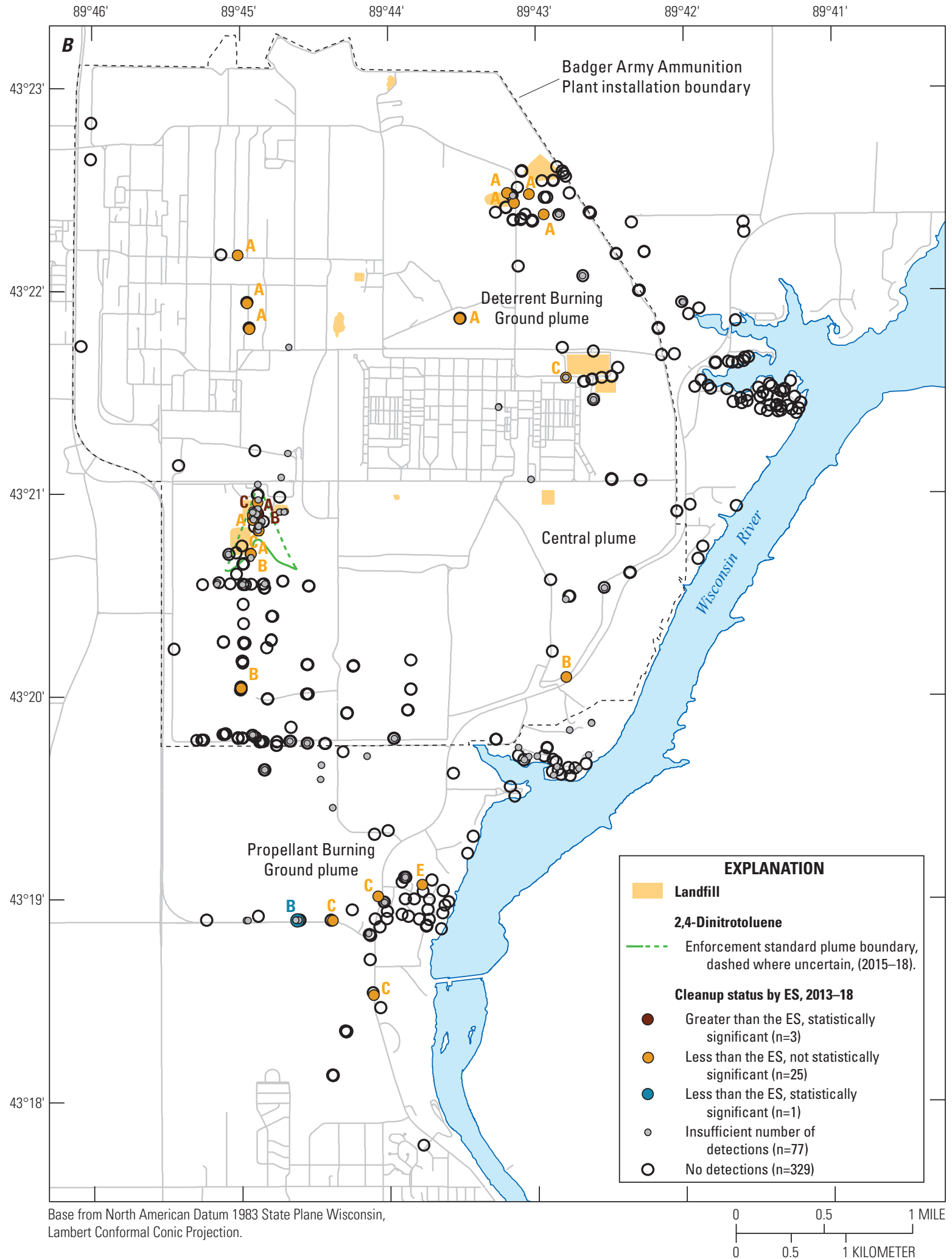

Figure 14.-Continued 


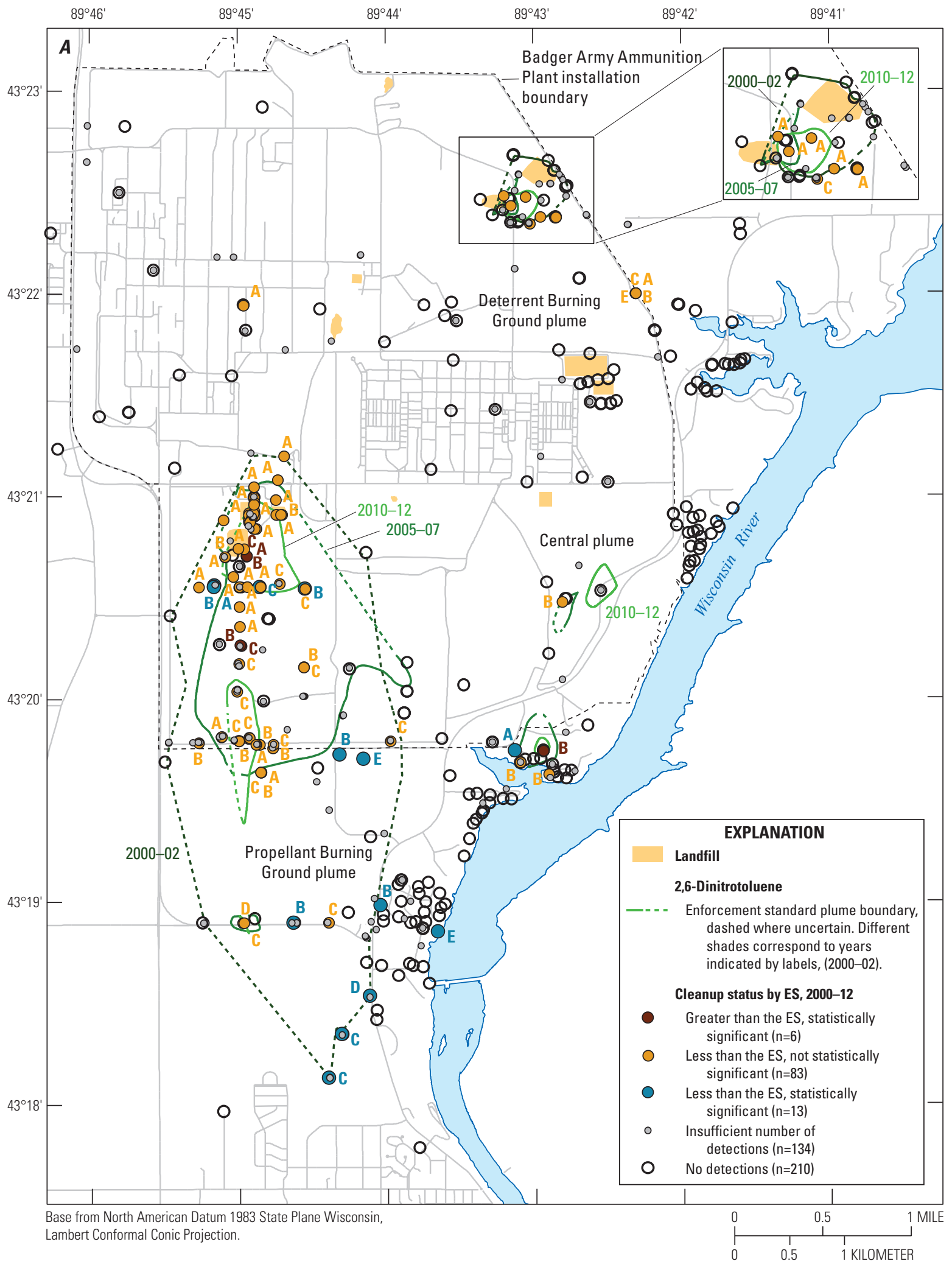

Figure 15. Map showing status of 2,6-dinitrotoluene remediation in monitoring wells relative to the Enforcement Standard, Badger Army Ammunition Plant, for A, 2000-12, and B, 2013-18. (2,6-DNT, 2,6-dinitrotoluene; ES, Enforcement Standard; $A$, well screen opening near the water table; $B$, well screen opening one-third from water table to bedrock; $C$, well screen opening two-thirds from water table to bedrock; D, well screen opening just above bedrock; $E$, well opening in the Eau Claire Formation) 


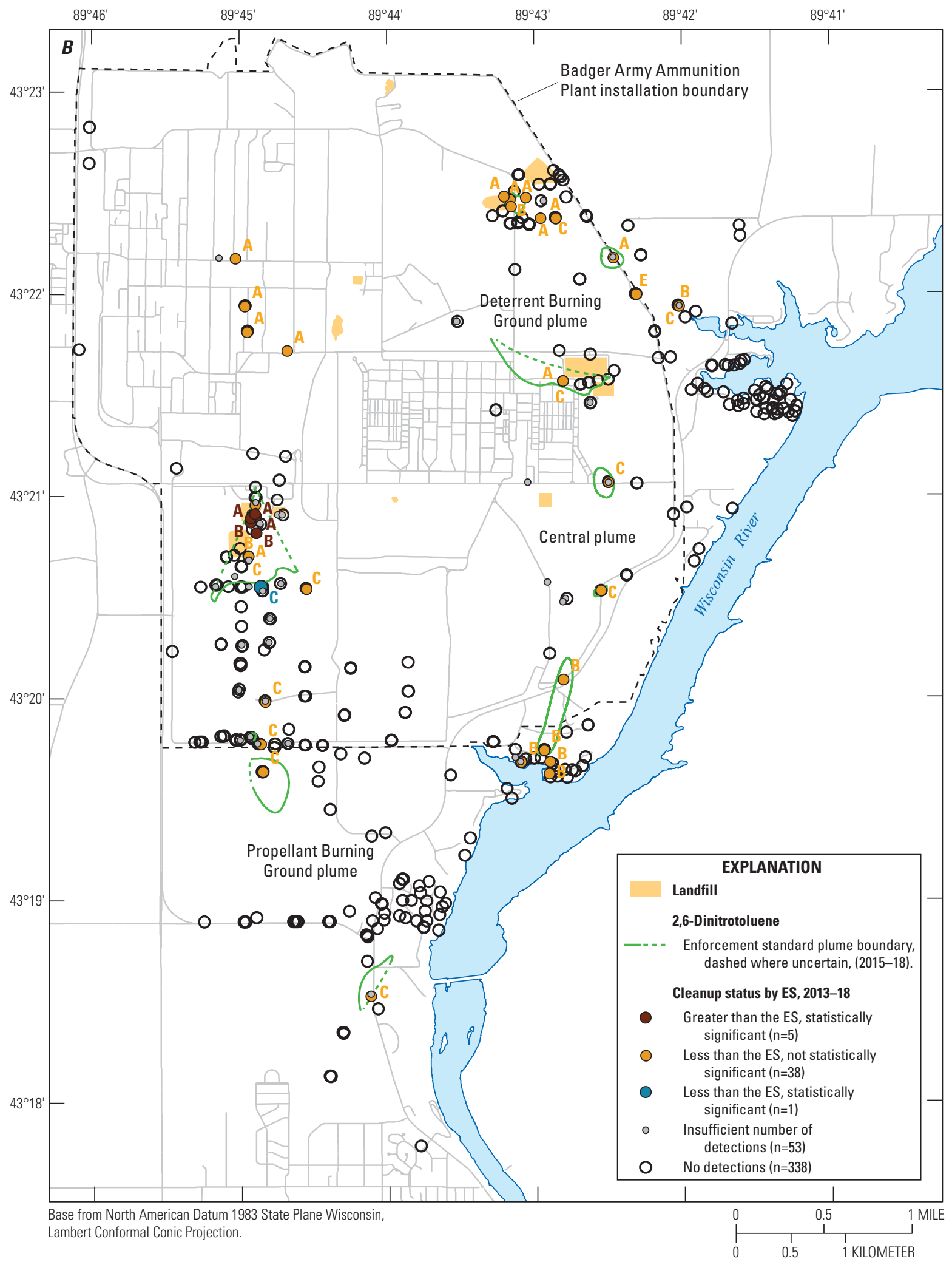

Figure 15.-Continued 


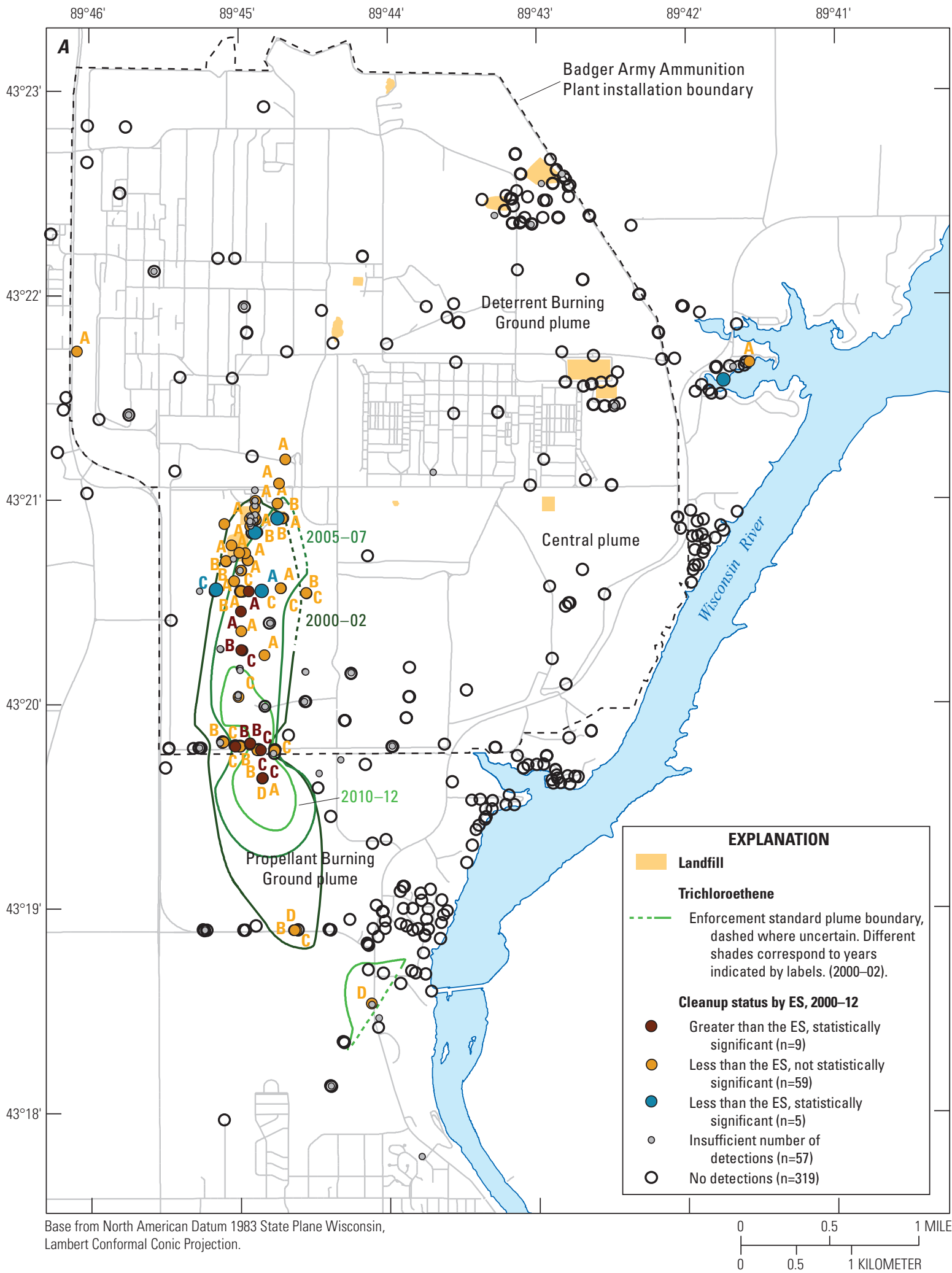

Figure 16. Map showing status of trichloroethene remediation in monitoring wells relative to the Enforcement Standard, Badger Army Ammunition Plant, for A, 2000-12 and B, 2013-18. (TCE, trichloroethene; ES, Enforcement Standard; $A$, well screen opening near the water table; $B$, well screen opening one-third from water table to bedrock; C, well screen opening two-thirds from water table bedrock; D, well screen opening just above bedrock; $E$, well opening in the Eau Claire Formation) 


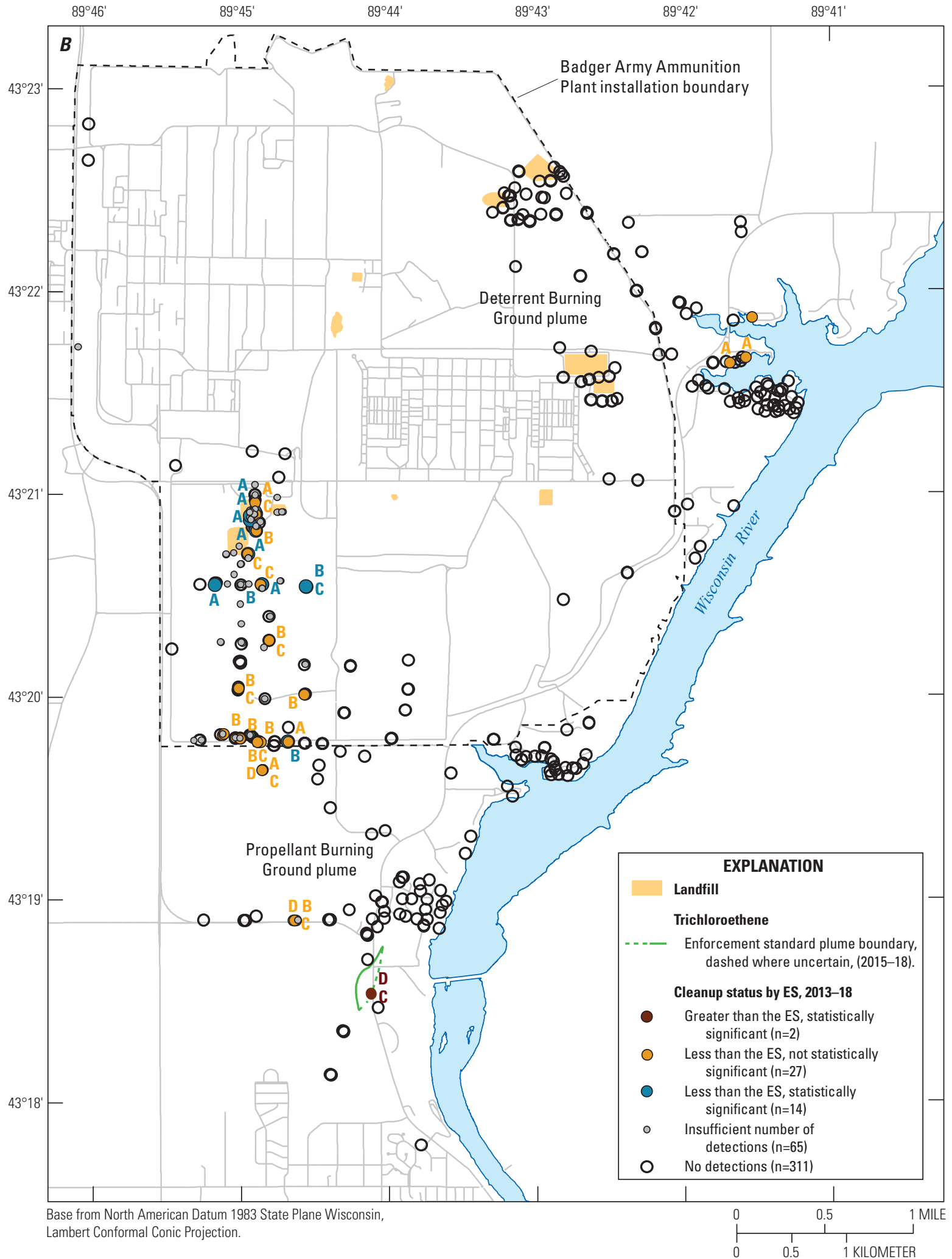

Figure 16.-Continued 


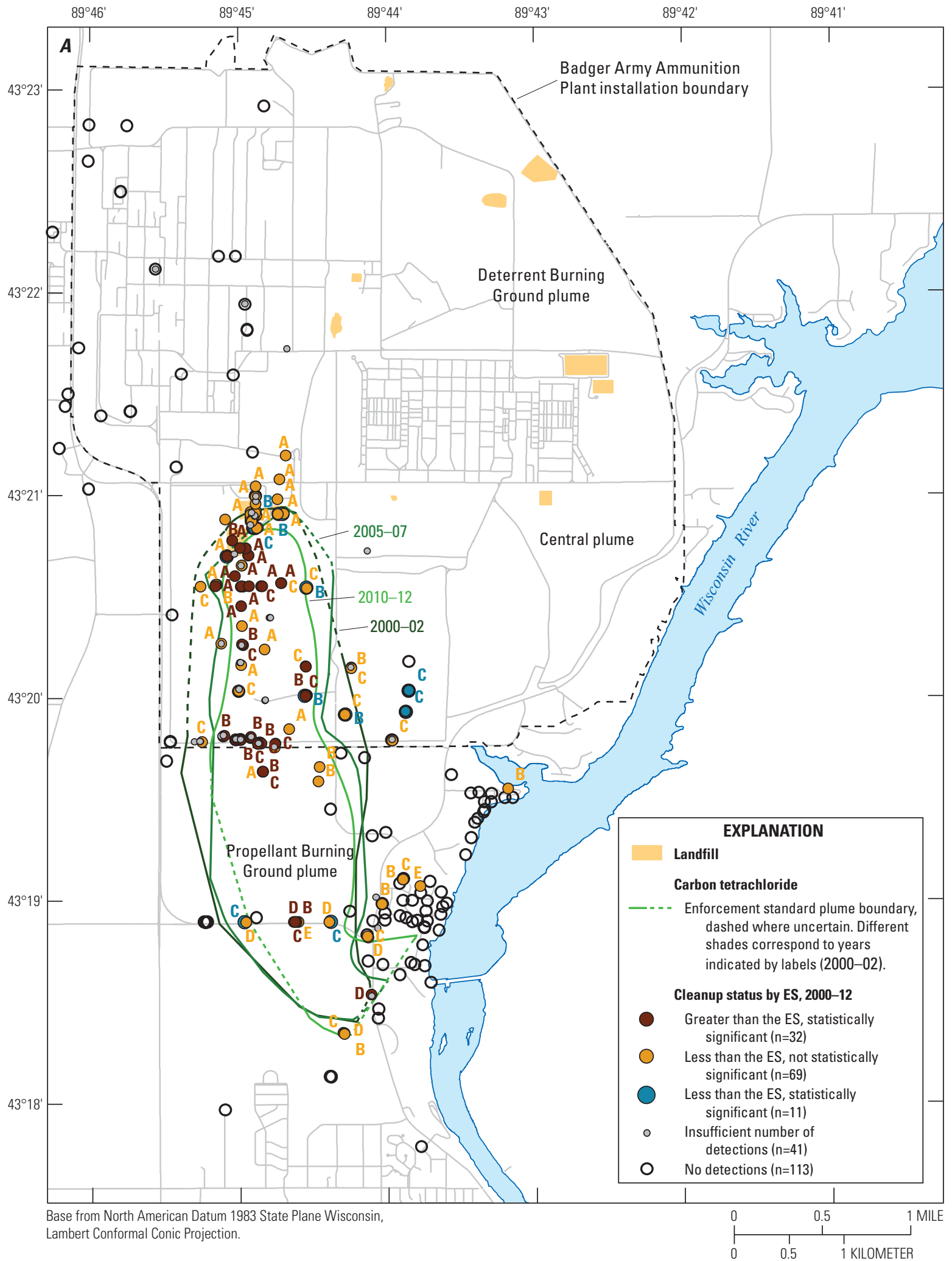

Figure 17. Map showing status of carbon tetrachloride remediation in monitoring wells relative to the Enforcement Standard, Badger Army Ammunition Plant, for A, 2000-12 and B, 2013-18. (CTET, carbon tetrachloride; ES, Enforcement Standard; $A$, well screen opening near the water table; $B$, well screen opening one-third from water table to bedrock; $C$, well screen opening two-thirds from water table to bedrock; $D$, well screen opening just above bedrock; $E$, well opening in the Eau Claire Formation) 


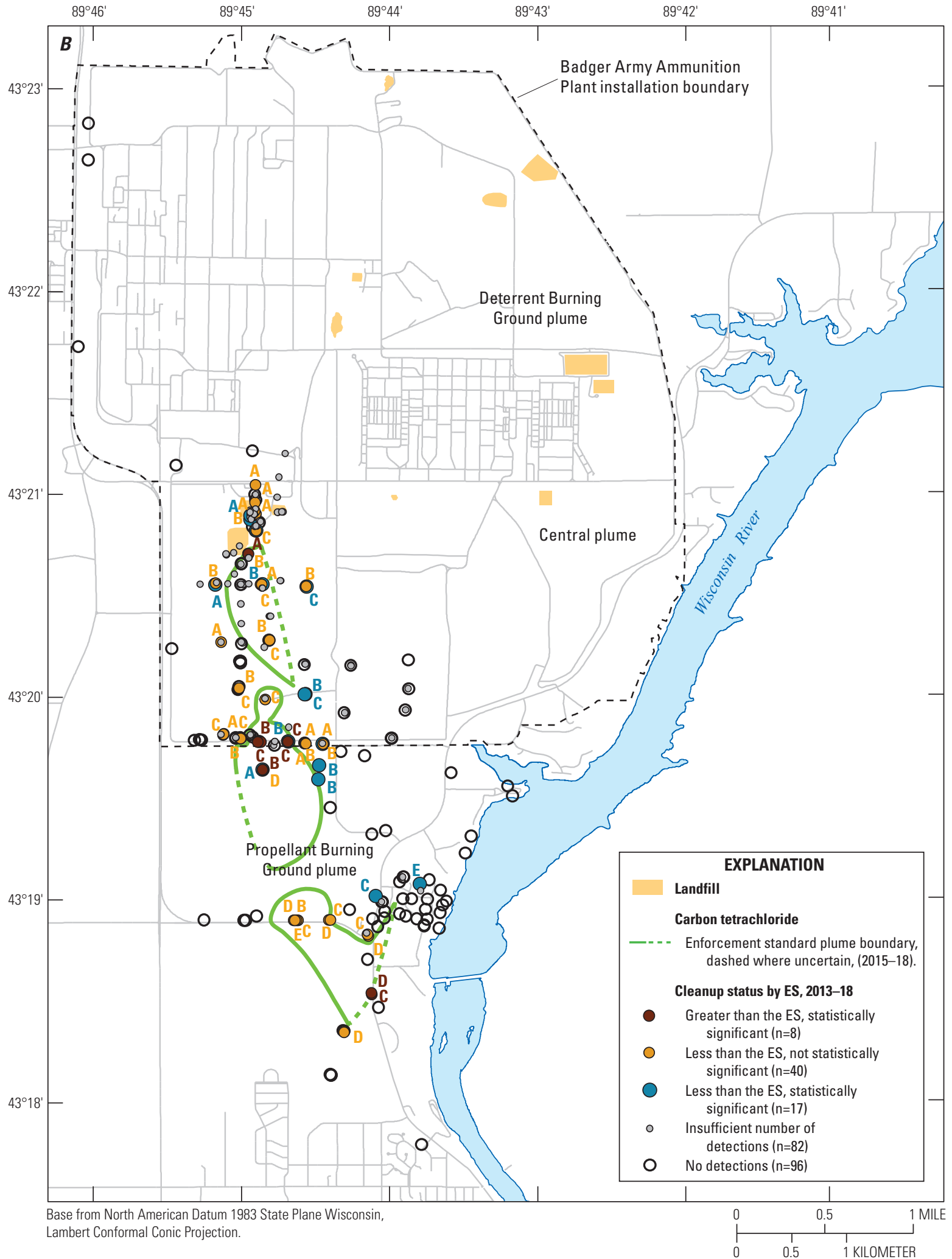

Figure 17.-Continued 


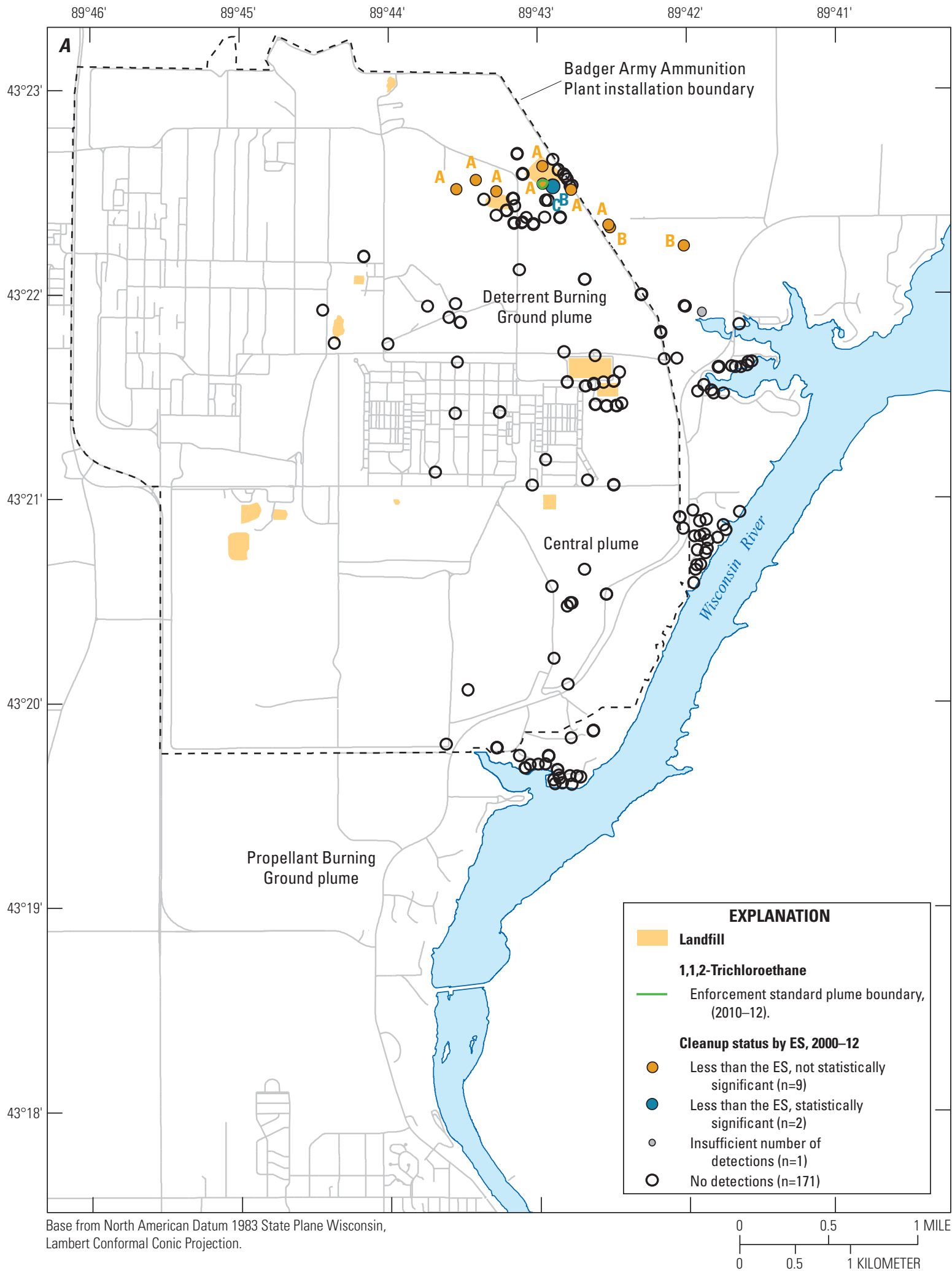

Figure 18. Map showing status of 1,1,2-trichloroethane remediation in monitoring wells relative to the Enforcement Standard, Badger Army Ammunition Plant study area, for A, 2000-12 and B, 2013-18. (1,1,2-TCA, 1,1,2-trichloroethane; ES, Enforcement Standard; A, well screen opening near the water table; B, well screen opening one-third from water table to bedrock; $C$, well screen opening two-thirds from water table to bedrock; D, well screen opening just above bedrock; E, well opening in the Eau Claire Formation) 


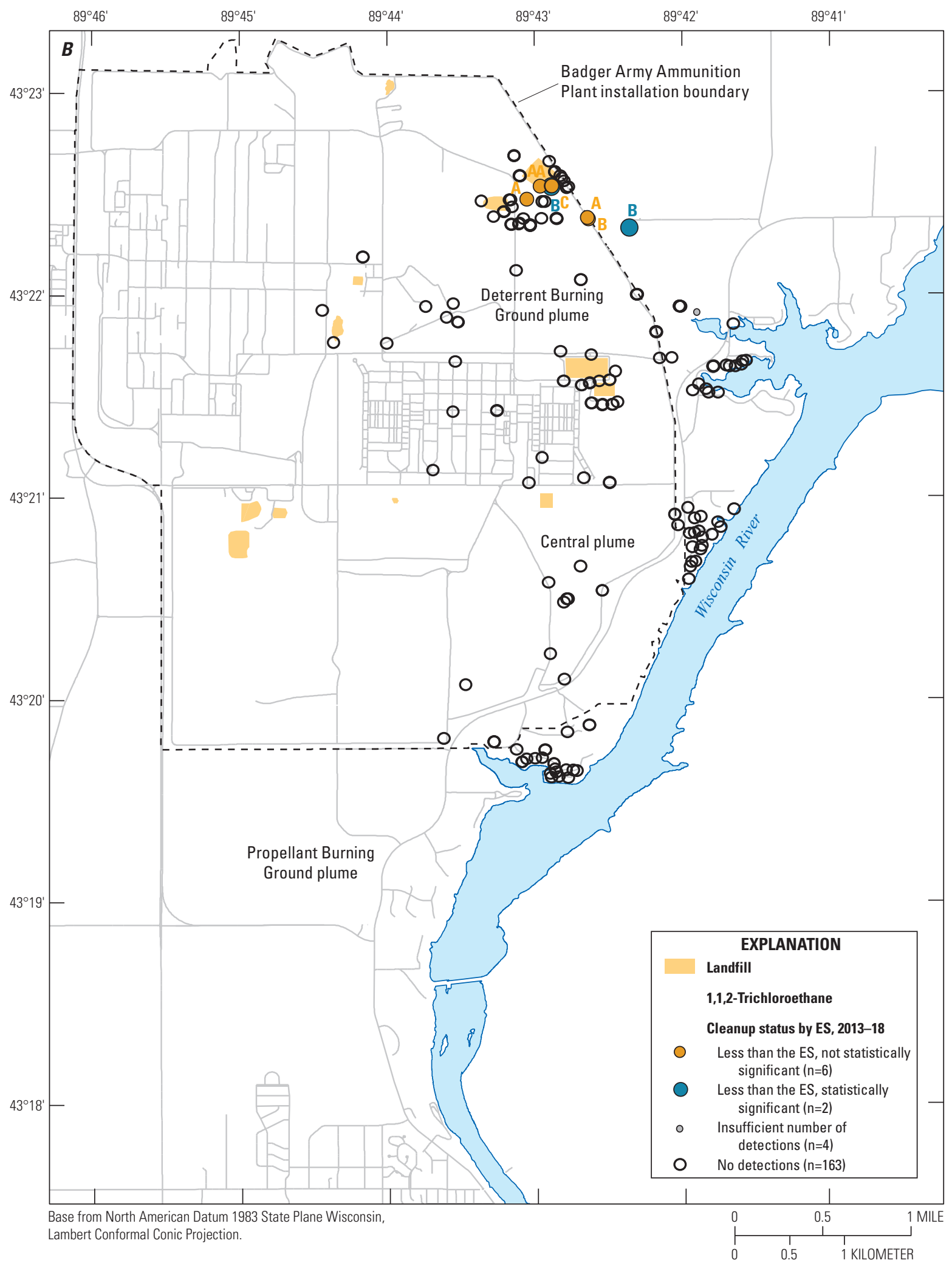

Figure 18.-Continued 


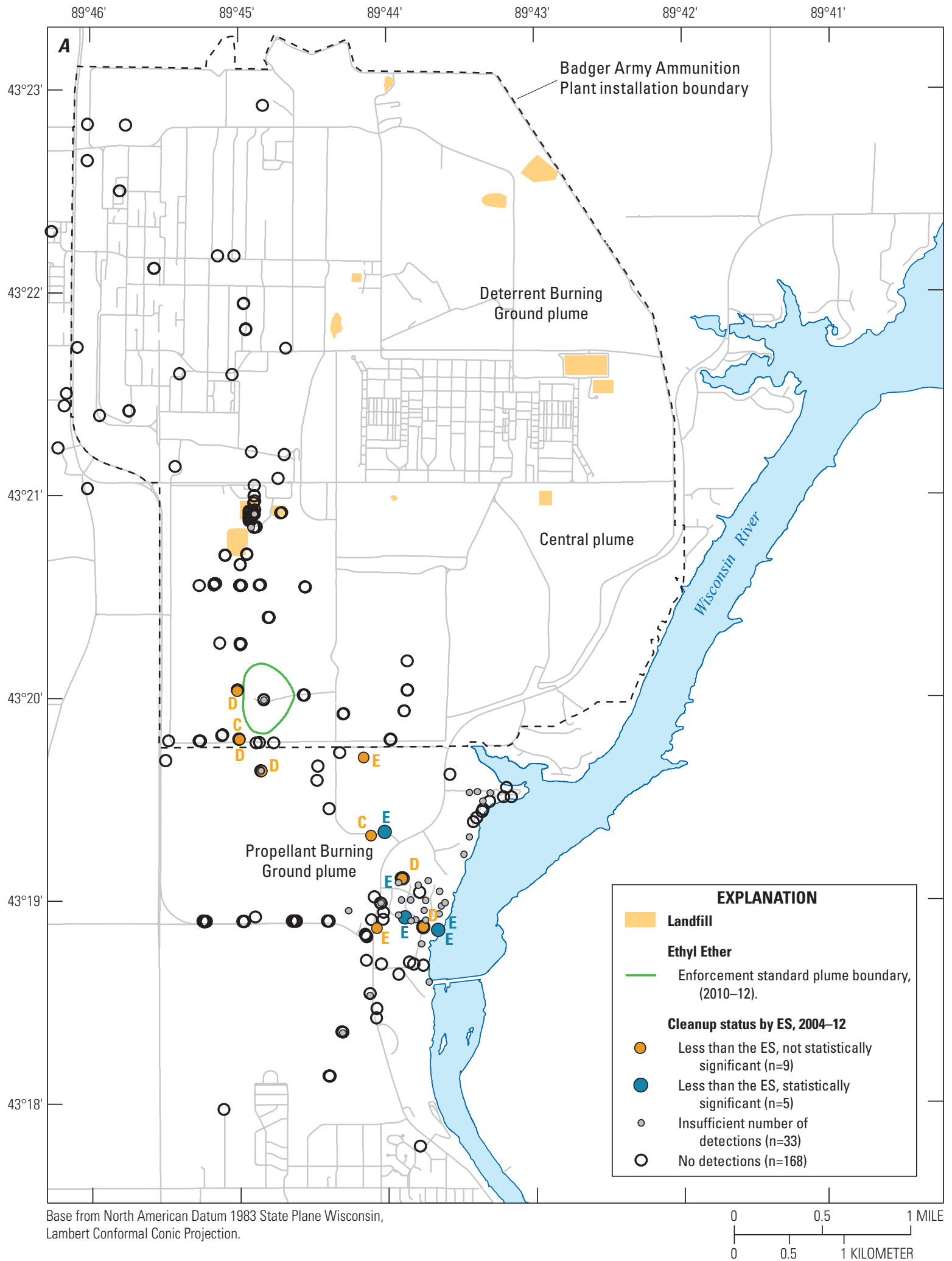

Figure 19. Map showing status of ethyl ether remediation in monitoring wells relative to the Enforcement Standard, Badger Army Ammunition Plant, for A, 2004-12 and B, 2013-18. (EE, ethyl ether; ES, Enforcement Standard; A, well screen opening near the water table; $B$, well screen opening one-third from water table to bedrock; $C$, well screen opening two-thirds from water table to bedrock; D, well screen opening just above bedrock; $E$, well opening in the Eau Claire Formation) 


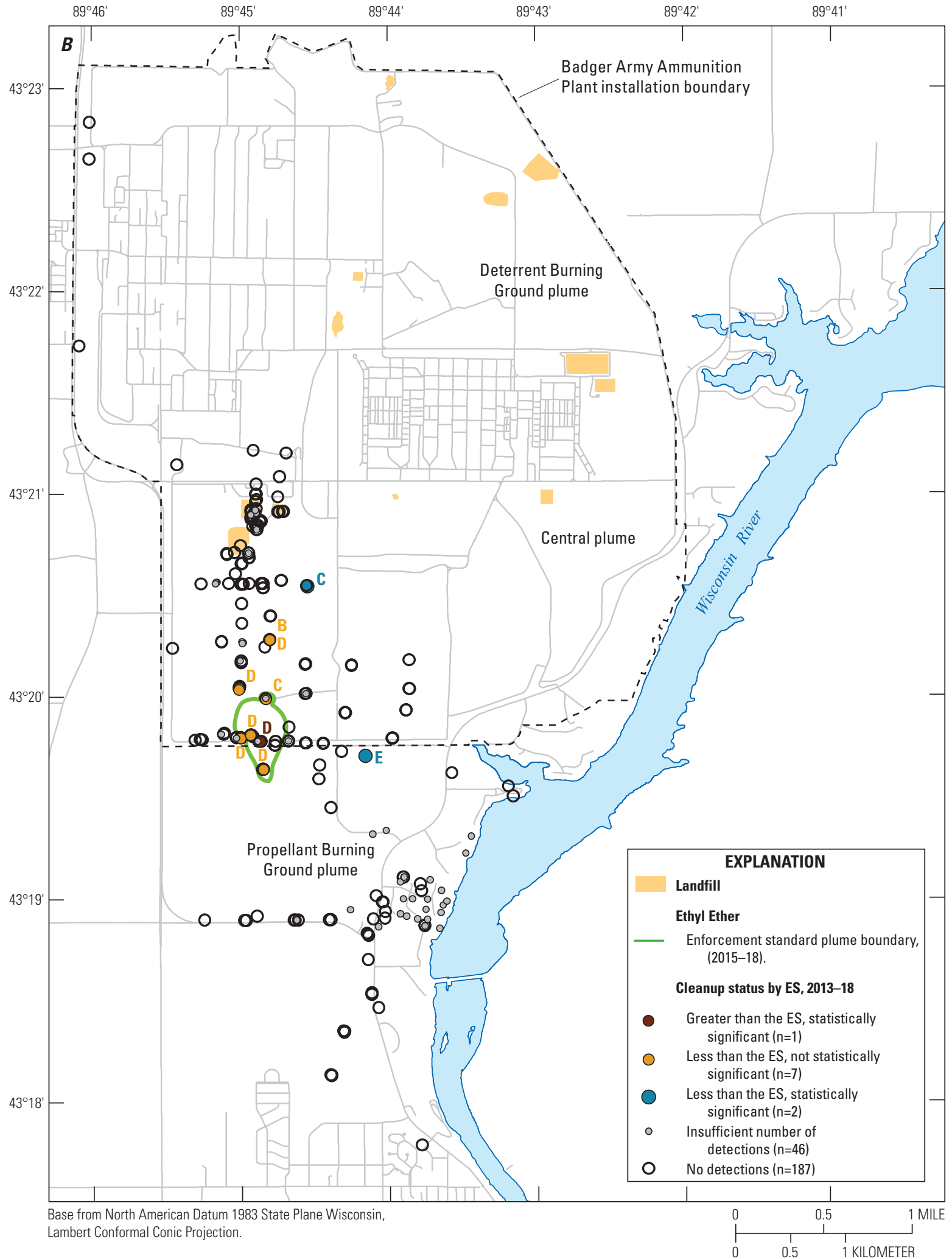

Figure 19.-Continued 


\section{Optimization of Sampling Frequency}

A total of 179 wells had sufficient concentration data and trend results to allow sampling frequency to be analyzed for at least one COC. Recommended sampling frequencies determined by the MAROS software were quarterly, semi-annual, annual, or biennial for a given contaminant in an individual well (table 22). In many cases, different sampling frequencies were recommended for different contaminants in the same well. There were no wells with a recommended sampling frequency for all seven COCs.

No recommendations for sampling frequency were made for any wells in the Central plume owing to an insufficient number of detections to perform the optimization analysis. For the DBG plume, an insufficient number of detections limited the frequency analysis to 7 wells, 6 in each of the time periods and only for 2,4-DNT in the 2000-12 period and 2,6-DNT in the 2013-18 period. For all seven DBG wells, the analysis resulted in a recommended biennial sampling frequency.

For the PBG plume, recommended sampling frequencies ranged from quarterly to biennial, with biennial being the most common. Results varied greatly between the 2000-12 period and the 2013-18 period. The different frequency recommendations between the two periods were driven by differences in availability of data as well as differences in trends and remediation status for each well. For the 2013-18 period, 204 COC sampling frequency recommendations were made for 104 wells by the MAROS software. For most wells, recommendations were made for only one COC; when a recommendation was made for more than one COC, the sampling frequencies were often different. Historically, groundwater sampling at BAAP has followed consistent sampling frequencies for all COCs in a well. Results of the sampling frequency analysis could be used to reduce sampling frequency for some COCs if analyses for all COCs were not required each time a well was sampled.

\section{Spatial Optimization of Well Locations}

Not all wells could be included in the spatial optimization analysis. The analysis to identify redundant wells is valid only for wells with at least four detections and in plume depth intervals with at least six wells with sufficient detection data. Wells were sometimes identified as redundant for one COC but not for another COC sampled within the same well. Generally, it was assumed that if sampling were going to continue for any contaminant in a well, then it would continue for all other contaminants as well. Therefore, wells were assigned an overall redundant classification only if they were either listed as redundant for all COCs or had no detections for all remaining COCs analyzed (table 1). No wells in the Central plume had enough detections for analysis to be performed for any COC. Of the seven wells in the DBG plume with enough data for the optimization, no wells were listed as redundant for any COC; therefore, results are reported only for the PBG.
For the 2000-12 period, eight wells were identified as redundant (table 23, fig. 20), indicating they provided no additional, statistically significant information about plume concentrations beyond what could be learned from nearby wells. For the 2013-18 period, there were six redundant PBG wells. (fig. 20).

Each of the three plumes were analyzed for the 2013-18 period to determine whether the well coverage was sufficient to delineate plume boundaries or whether additional wells would be needed in the future and their potential locations. A limited number of depth intervals for each COC could be evaluated owing to limitations on the number of wells with detections required by the MAROS software to conduct the analysis. No areas were identified for the addition of wells.

\section{Effect of Network Well Removal on Plume Boundary Delineation}

The number of wells used to create the plume boundary decreased by 104 between 2010-12 and 2015-18 (table 24). An analysis of these wells shows that there are several reasons for the decreased number of wells in the 2015-18 period. First, 24 private wells around all three plumes were removed from the sampling program following an evaluation of the private wells in a 2013 Private Well Sampling Reduction Plan (Badger Technical Services, 2013a). The reasons given for removing the private wells were typically that no contaminants were consistently detected in the wells and that the wells were outside any plume boundary or plume pathway. Second, 32 monitoring wells were removed from the sampling network in the Central plume and DBG plume as part of the 2014 Monitoring Well Optimization Plan (Badger Technical Services, 2014a). The rationale provided for the removals included "Not needed," "Well is clean," and "Not needed upgradient." The same report proposed changing the sampling frequency for certain wells monitoring the Central and DBG plumes and proposed that some additional monitoring wells be installed in both plumes. Third, in a January 5, 2015, memo, the Wisconsin Department of Natural Resources defined which monitoring wells should be sampled to evaluate the PBG plume, implying that wells not listed are not required to be sampled (Woody Myers, Project Manager, Wisconsin Department of Natural Resources, written commun., 2015). The list of wells in the memo is not identical to the list for which there are historical sampling results, so wells may have been removed from the sampling network during this stage. Fourth, some private wells appear to have been sampled infrequently and not as part of a regular sampling plan. There are 19 private wells that were sampled in February 2007 and April 2011. Sample results from these wells were useful for 2005-07 and 2010-12 plume delineations, but no results were available for the 2015-18 plume delineations.

The locations of wells that were sampled during 2010-12 and not sampled during 2015-18 are displayed within the mapped plume boundaries (plates 3-6 and 7-16) to allow 
an evaluation of the current well network. The 104 wells displayed as removed from the network meet the following conditions:

1. the wells were sampled for any of the seven COCs during the 2010-12 sampling period,

2. the wells were not sampled for any of the seven COCs during 2015-18 sampling period, and

3. the wells have a depth interval assignment (A-F) and are assigned to a plume.

Removing wells from the sampling network after 2012 had, in some cases, the effect of reducing certainty over the well plume delineations. In the Central plume, wells removed from the sampling network after 2012 did not affect the ability to delineate COC concentrations in relation to the ES. In the PBG, several private wells between the plume and the Wisconsin River were removed from the sampling network. Removing these wells introduced more uncertainty over the downgradient plume boundaries for TCE (C layer northeast of well PBN-9101C; plate 1D), total DNT (C layer), and CTET (C and D layers). Removing all three A layer wells (SPN-0401A, SPN-0402A, SPN-0403A) east of the middle CTET plume leads to uncertainty in defining the edge of the east side of the upper CTET plume in the A layer (plate 2D). Although these wells are far from the plume, they are the closest A layer wells used in this analysis. Retaining at least one of these wells in the sampling network would reduce uncertainty on the eastern CTET ES plume edge. On the east side of the PBG plume source area, wells LON-8903A and LON-8903B were removed, adding uncertainty about the eastern edge of the plume in the A and B layers for the DNT contaminants (plates 3-5). The same is true for wells PBN-8203A and PBN-8203C on the southwestern edge of the source area in the A and C layers (plates 3-5). The uncertainty at the western edge of the CTET plume was not affected by the well removals during $2012-15$ because the only B layer well that could assist with delineation (SWN-9101B) was not sampled in the 2010-12 period.

In the DBG plume, some wells removed from the sampling network after 2012 increased uncertainty over the plume delineation upgradient from the source area for the DNT contaminants in the A and B layers. Removing wells S1122, DBN-8201B, ELN-8204A, ELN-8204B, and DBM-1001 led to uncertainty about the upgradient edge of the plume. South and west of the plume, well DBM-9501 (A layer) was removed after 2012. Removing this well affected the shape of the plume as calculated using natural-neighbor interpolation. However, removing the well did not lead to uncertainty in delineation. The well removals did not affect the downgradient edge of the DBG plume.

\section{Wells Identified as Redundant}

The eight wells identified as redundant as a result of the optimization analysis for the 2000-12 period were subsequently sampled at least once during the 2015-18 period. For four of the wells, the optimization analysis could not be repeated in the later time period for the same contaminants because the wells either had no detections (PBN-9902A and PBN-9304A) or fewer than four detections (PBN-9901B and S1102). Those four wells were not identified as important for the plume boundary delineations either, supporting a conclusion that they do not add significantly to the monitoring network. One well (SPN-0402C) was again identified in the later time period as redundant for the same COC, which supports its removal from the network. Three wells (SWN-0503E, 3497862, and SWN-9104D) later were identified as important to retain for the plume analyses for the same contaminants for which they previously had been identified as redundant. The change in the results seems to be related to the elimination of other nearby wells between 2012 and 2015 . When those other wells were removed, these three became more important to the ability to monitor the status of the plume.

The optimization analysis for the 2013-18 period identified five wells as redundant, in addition to the one well discussed above which was redundant in both time periods. Those five wells are not in areas where their absence would have a significant effect on the ability to delineate a plume boundary because other nearby wells provide information on the concentration of the subject contaminant (table 23).

Many more wells were considered redundant for one or more COCs but were not redundant for at least one other COC. A careful review of the results could support the removal of specific COCs from the list of analytes for those wells, provided that the COC at a certain well location is not important to the plume boundary delineation. A table of the optimization results for all wells is available in the accompanying data release (Metes and others, 2020). 


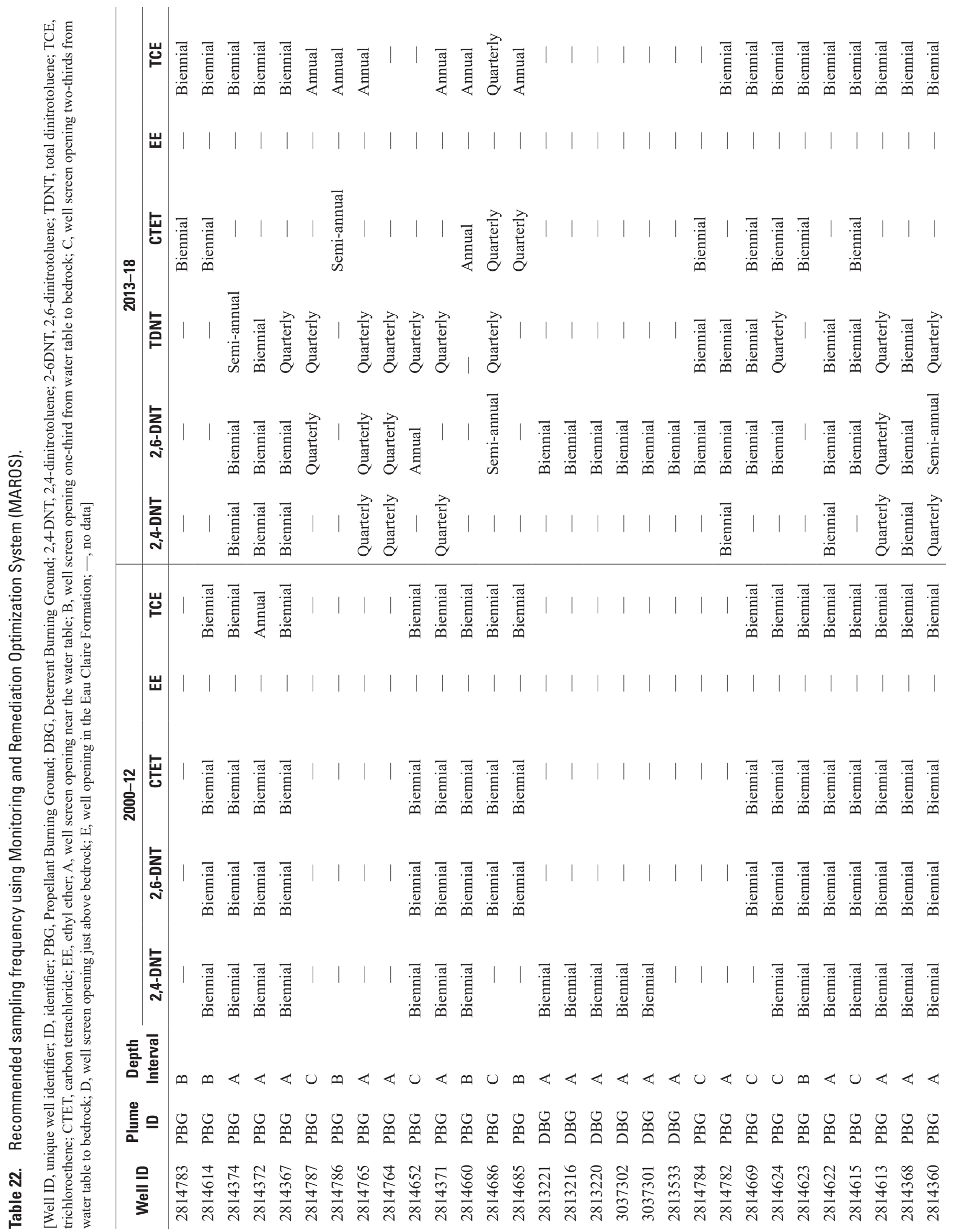




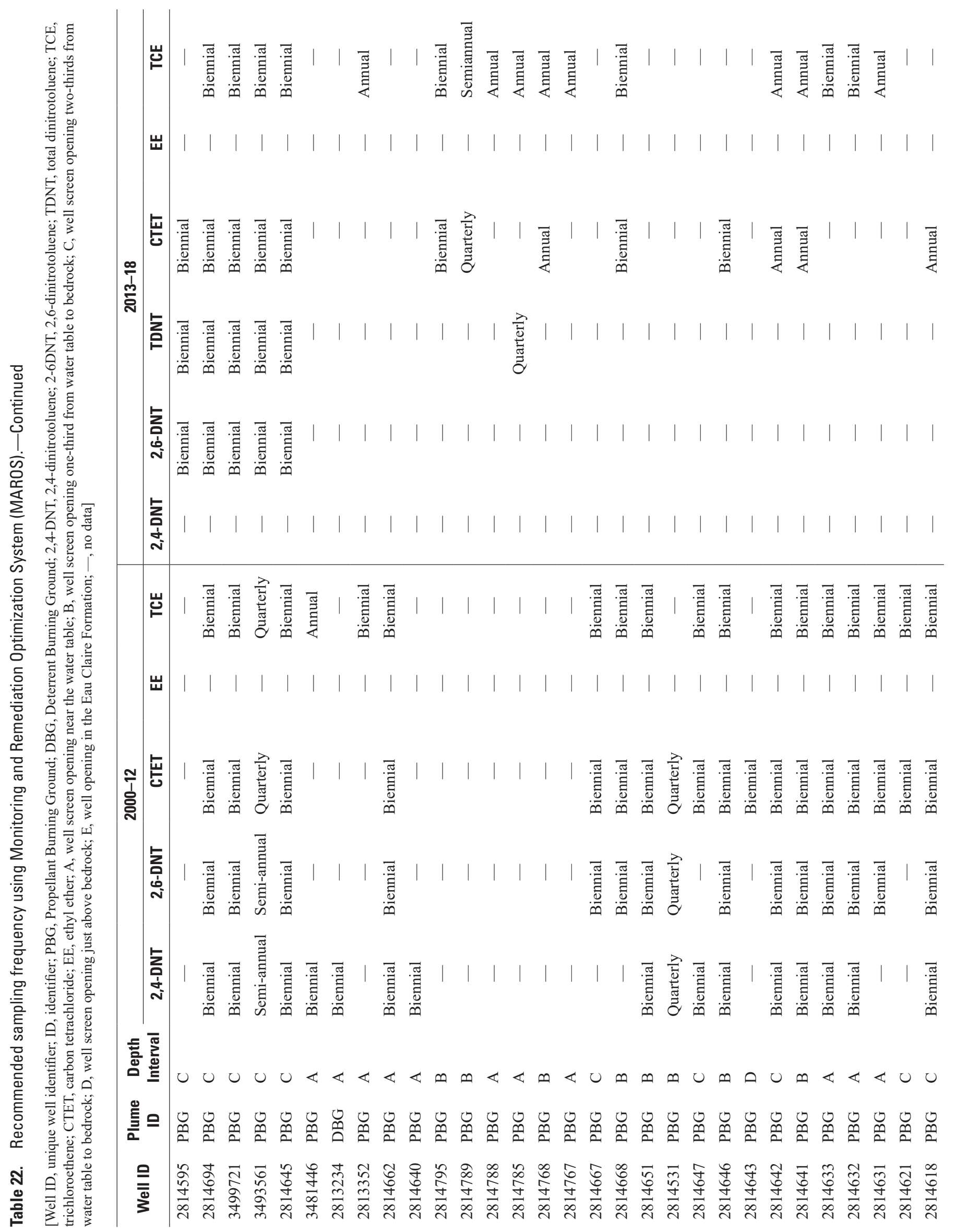




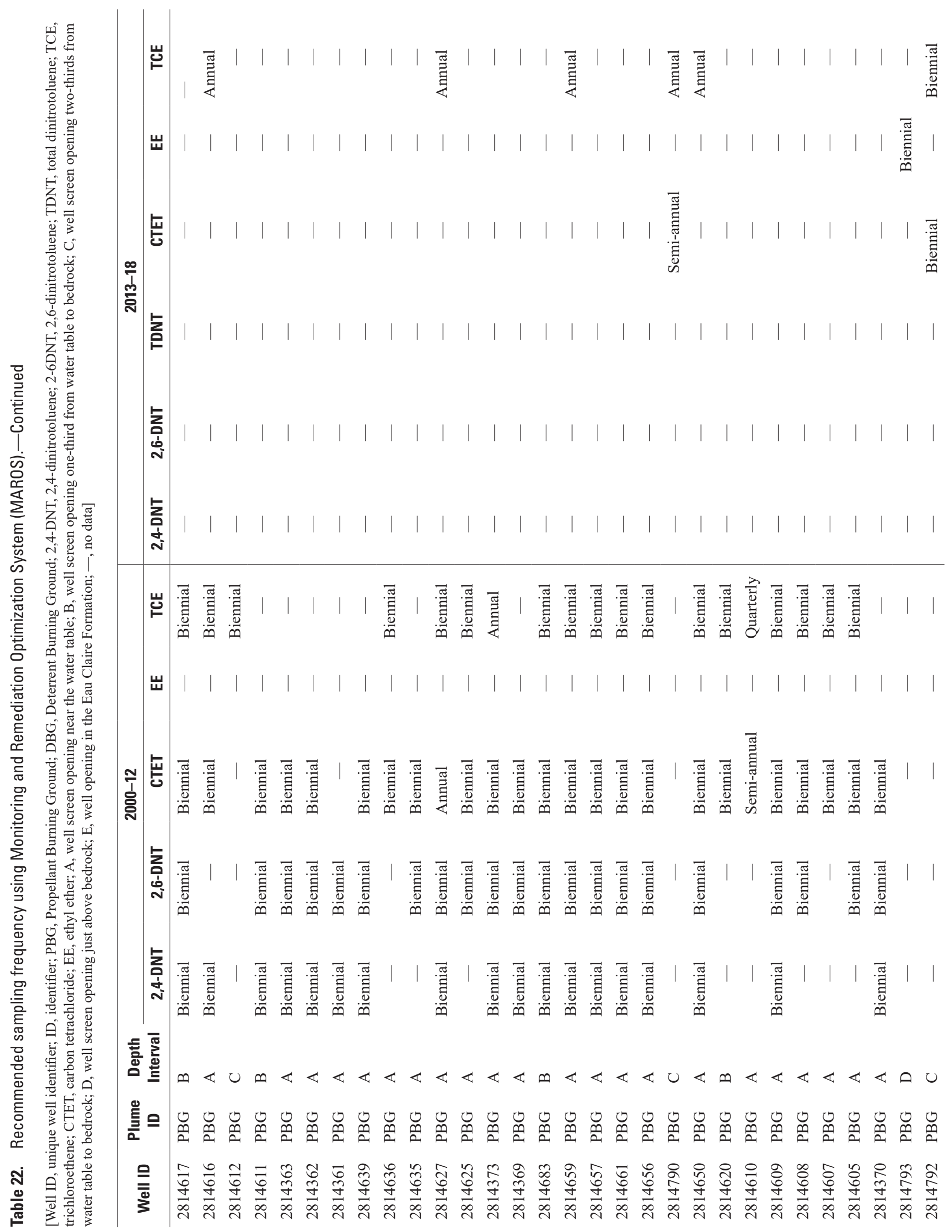




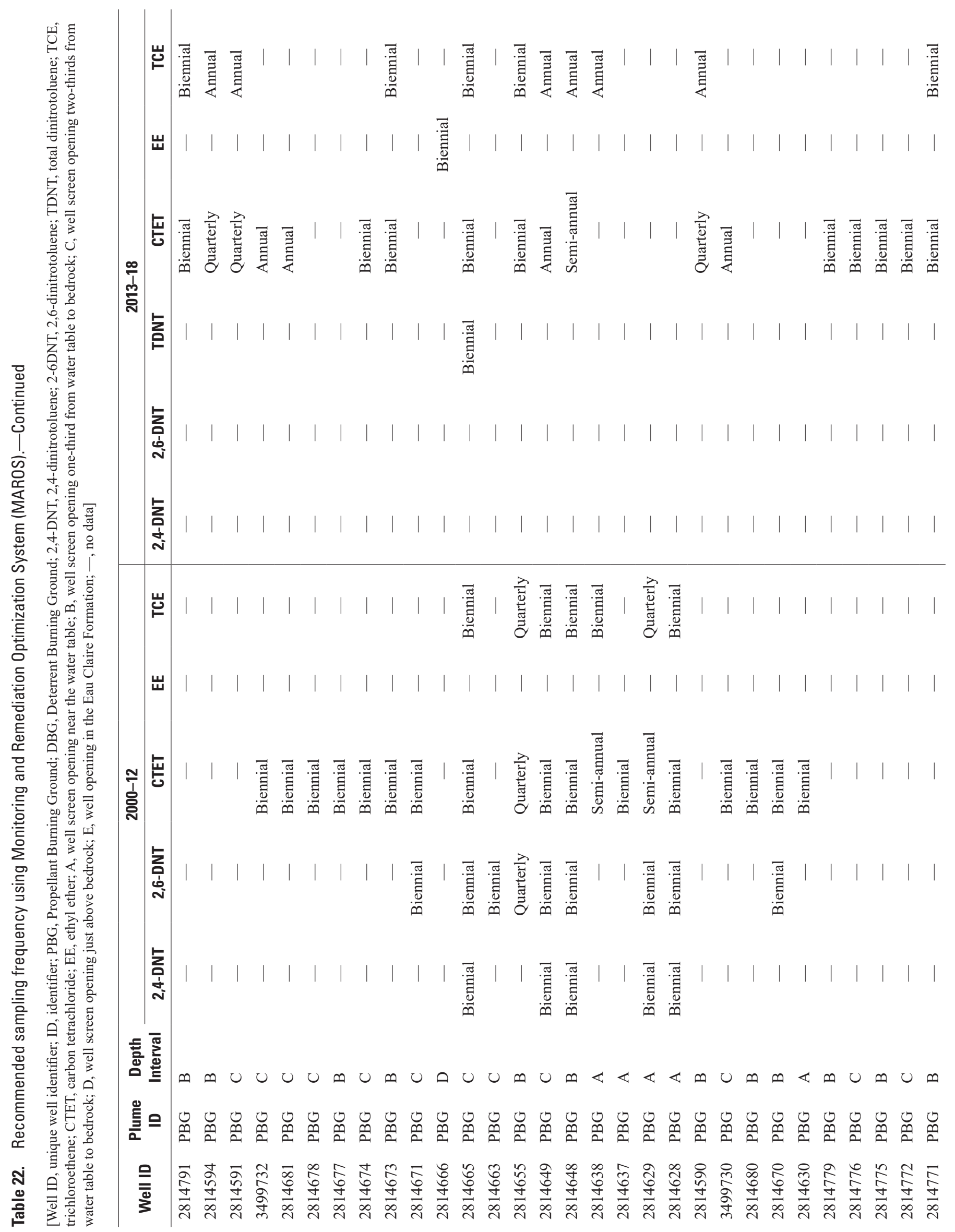




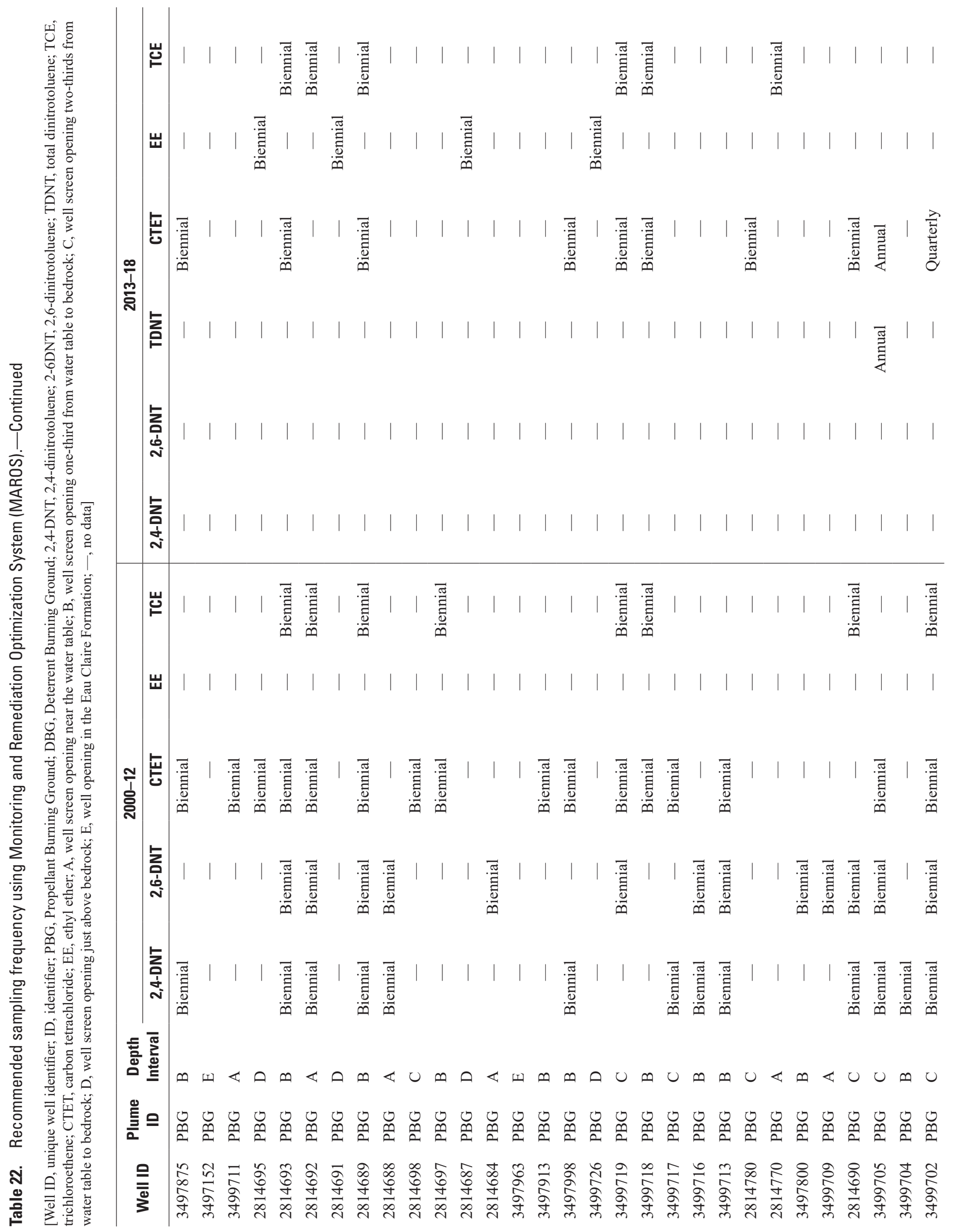




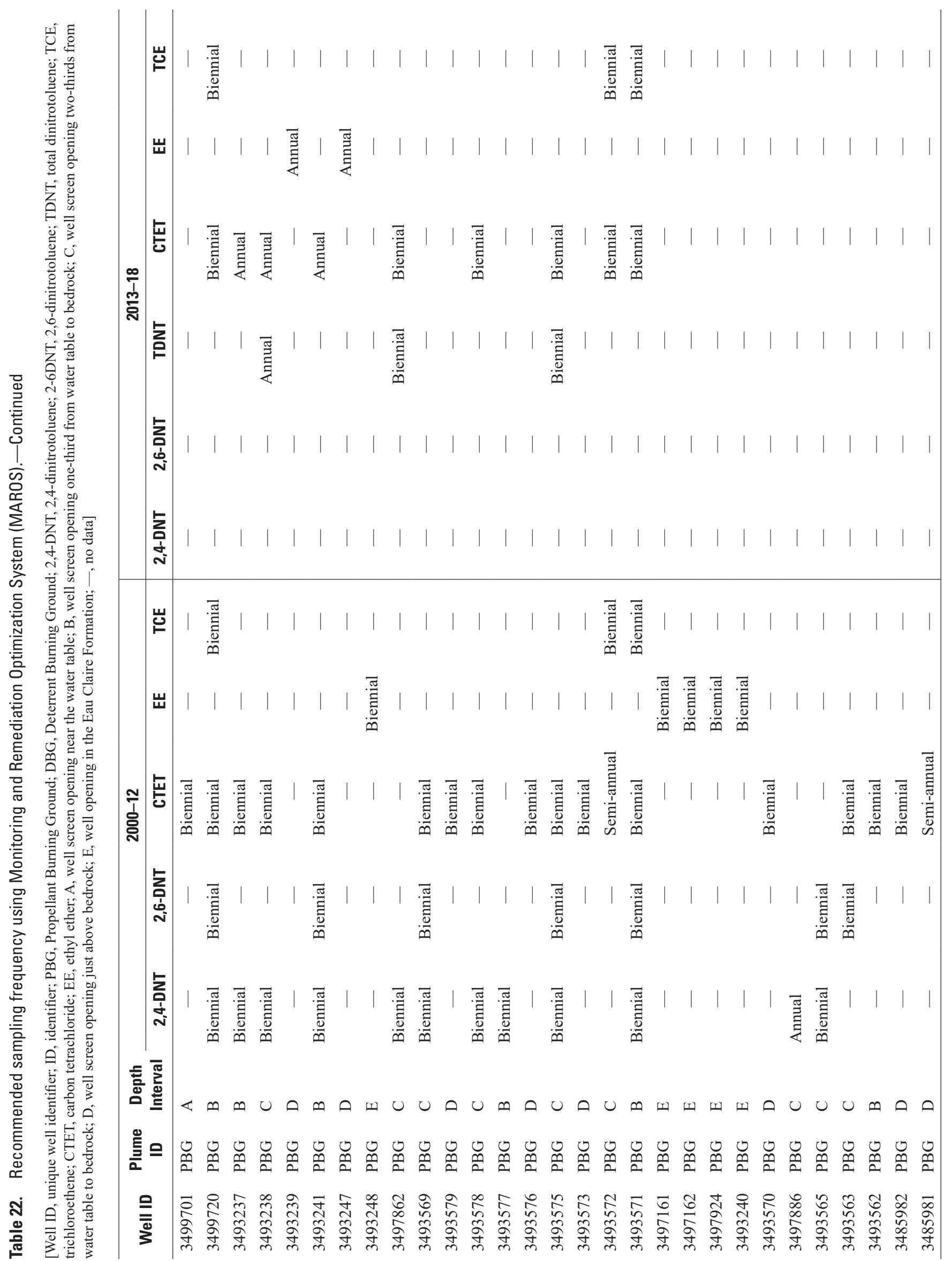


Table 23. Wells identified as providing redundant information for any contaminant of concern, Badger Army Ammunition Plant.

[Well ID, unique well identifier; 2,4-DNT, 2,4-dinitrotoluene; 2,6-DNT, 2,6-dinitrolouene; TDNT, total dinitrotoluene; CTET, carbon tetrachloride; EE, ethyl ether; TCE, trichloroethene; A, well screen opening near the water table; B, well screen opening on-third from water table to bedrock; C, well screen opening two-thirds from water table to bedrock; D, well screen opening just above bedrock; E, well opening in the Eau Clair Formation; green cell with X, well not important for plume delineation; orange cell with dot, well important for plume delineation; dark gray cell with -, well not sampled; medium gray cell with --, well not assessed (no detections); light gray cell with ---, well not assessed (insufficient number of detections)]

\begin{tabular}{|c|c|c|c|c|c|c|c|c|}
\hline $\begin{array}{l}\text { Depth } \\
\text { interval }\end{array}$ & Well ID & Time Period & 2,4-DNT & 2,6-DNT & TDNT & CTET & EE & TCE \\
\hline \multirow[t]{2}{*}{ C } & 2814787 & 2000-12 & - & . & - & - & - & - \\
\hline & & 2013-18 & $\bullet$ & $\bullet$ & $\mathbf{X}$ & --- & -- & $\bullet$ \\
\hline \multirow[t]{2}{*}{ A } & 2814785 & $2000-12$ & - & - & - & - & - & - \\
\hline & & 2013-18 & --- & --- & $\bullet$ & $\bullet$ & -- & $\mathbf{x}$ \\
\hline \multirow[t]{2}{*}{ A } & 2814765 & 2000-12 & --- & --- & --- & --- & -- & --- \\
\hline & & 2013-18 & $\mathbf{X}$ & - & - & • & -- & • \\
\hline \multirow[t]{2}{*}{ A } & 2814764 & $2000-12$ & --- & --- & --- & --- & -- & --- \\
\hline & & 2013-18 & $\mathbf{X}$ & - & - & --- & -- & --- \\
\hline \multirow[t]{2}{*}{ C } & 2814652 & 2000-12 & - & $\bullet$ & -- & - & -- & $\bullet$ \\
\hline & & 2013-18 & --- & $\mathbf{X}$ & $\mathbf{X}$ & --- & -- & -- \\
\hline \multirow[t]{2}{*}{ C } & 2814645 & 2000-12 & $\bullet$ & $\bullet$ & -- & - & -- & $\mathbf{X}$ \\
\hline & & 2013-18 & -- & $\mathbf{X}$ & $\bullet$ & $\bullet$ & -- & $\bullet$ \\
\hline \multirow[t]{2}{*}{$\mathrm{C}$} & 2814642 & $2000-12$ & $\mathbf{x}$ & $\bullet$ & -- & $\bullet$ & -- & $\mathbf{X}$ \\
\hline & & 2013-18 & -- & -- & -- & $\bullet$ & -- & $\bullet$ \\
\hline \multirow[t]{2}{*}{ A } & 2814633 & 2000-12 & $\bullet$ & $\bullet$ & -- & $\mathbf{x}$ & -- & $\bullet$ \\
\hline & & 2013-18 & -- & -- & -- & $\bullet$ & -- & $\bullet$ \\
\hline \multirow[t]{2}{*}{ A } & 2814632 & $2000-12$ & $\bullet$ & $\bullet$ & -- & $\mathbf{x}$ & -- & $\bullet$ \\
\hline & & 2013-18 & -- & --- & --- & $\bullet$ & -- & • \\
\hline \multirow[t]{2}{*}{ A } & 2814631 & 2000-12 & --- & $\mathbf{X}$ & -- & $\mathbf{X}$ & -- & $\bullet$ \\
\hline & & 2013-18 & -- & -- & --- & $\bullet$ & -- & $\bullet$ \\
\hline \multirow[t]{2}{*}{$\mathrm{C}$} & 2814624 & 2000-12 & $\mathbf{X}$ & $\bullet$ & --- & $\bullet$ & -- & $\mathbf{X}$ \\
\hline & & 2013-18 & $\bullet$ & $\bullet$ & $\bullet$ & $\bullet$ & --- & $\bullet$ \\
\hline \multirow[t]{2}{*}{ A } & 2814622 & $2000-12$ & $\bullet$ & $\bullet$ & --- & $\mathbf{X}$ & -- & $\bullet$ \\
\hline & & 2013-18 & $\bullet$ & - & - & $\bullet$ & -- & $\bullet$ \\
\hline \multirow[t]{2}{*}{ C } & 2814621 & $2000-12$ & -- & --- & --- & $\bullet$ & -- & $\mathbf{X}$ \\
\hline & & 2013-18 & -- & -- & -- & -- & -- & --- \\
\hline \multirow[t]{2}{*}{ A } & 2814616 & $2000-12$ & $\bullet$ & --- & --- & $\mathbf{x}$ & -- & $\bullet$ \\
\hline & & 2013-18 & --- & -- & --- & $\bullet$ & --- & $\bullet$ \\
\hline \multirow[t]{2}{*}{ A } & 2814363 & 2000-12 & - & $\mathbf{X}$ & --- & $\mathbf{x}$ & -- & --- \\
\hline & & 2013-18 & --- & --- & --- & --- & -- & --- \\
\hline \multirow[t]{2}{*}{ A } & 2814362 & $2000-12$ & - & $\mathbf{X}$ & --- & $\mathbf{X}$ & -- & --- \\
\hline & & 2013-18 & --- & --- & --- & --- & -- & --- \\
\hline \multirow[t]{2}{*}{ A } & 2814361 & 2000-12 & - & $\mathbf{X}$ & --- & --- & -- & --- \\
\hline & & 2013-18 & --- & --- & --- & -- & -- & -- \\
\hline \multirow[t]{2}{*}{ A } & 2814636 & 2000-12 & -- & --- & --- & $\mathbf{X}$ & - & - \\
\hline & & 2013-18 & -- & -- & -- & --- & -- & --- \\
\hline \multirow[t]{2}{*}{ A } & 2814627 & 2000-12 & $\bullet$ & X & --- & $\mathbf{x}$ & - & $\bullet$ \\
\hline & & 2013-18 & -- & --- & --- & • & -- & • \\
\hline
\end{tabular}


Table 23. Wells identified as providing redundant information for any contaminant of concern, Badger Army Ammunition Plant.Continued

[Well ID, unique well identifier; 2,4-DNT, 2,4-dinitrotoluene; 2,6-DNT, 2,6-dinitrolouene; TDNT, total dinitrotoluene; CTET, carbon tetrachloride; EE, ethyl ether; TCE, trichloroethene; A, well screen opening near the water table; B, well screen opening on-third from water table to bedrock; C, well screen opening two-thirds from water table to bedrock; D, well screen opening just above bedrock; E, well opening in the Eau Clair Formation; green cell with X, well not important for plume delineation; orange cell with dot, well important for plume delineation; dark gray cell with -, well not sampled; medium gray cell with --, well not assessed (no detections); light gray cell with ---, well not assessed (insufficient number of detections)]

\begin{tabular}{|c|c|c|c|c|c|c|c|c|}
\hline $\begin{array}{l}\text { Depth } \\
\text { interval }\end{array}$ & Well ID & Time Period & 2,4-DNT & 2,6-DNT & TDNT & CTET & EE & TCE \\
\hline \multirow[t]{2}{*}{ A } & 2814625 & $2000-12$ & --- & $\bullet$ & --- & $\mathbf{X}$ & - & $\bullet$ \\
\hline & & 2013-18 & -- & --- & --- & --- & -- & --- \\
\hline \multirow[t]{2}{*}{ A } & 2814374 & $2000-12$ & $\bullet$ & $\mathbf{X}$ & --- & $\mathbf{X}$ & -- & $\bullet$ \\
\hline & & 2013-18 & $\bullet$ & $\bullet$ & $\mathbf{X}$ & $\bullet$ & -- & $\mathbf{X}$ \\
\hline \multirow[t]{2}{*}{ A } & 2814373 & $2000-12$ & $\mathbf{X}$ & $\mathbf{X}$ & --- & $\mathbf{X}$ & -- & - \\
\hline & & 2013-18 & --- & --- & --- & --- & -- & --- \\
\hline \multirow[t]{2}{*}{ A } & 2814372 & $2000-12$ & $\bullet$ & $\mathbf{X}$ & --- & $\mathbf{X}$ & -- & $\bullet$ \\
\hline & & 2013-18 & $\mathbf{X}$ & $\mathbf{x}$ & $\bullet$ & $\bullet$ & --- & $\bullet$ \\
\hline \multirow[t]{2}{*}{ A } & 2814371 & $2000-12$ & $\bullet$ & $\mathbf{x}$ & --- & $\mathbf{x}$ & -- & $\bullet$ \\
\hline & & 2013-18 & • & - & $\bullet$ & $\bullet$ & -- & $\mathbf{X}$ \\
\hline \multirow[t]{2}{*}{ A } & 2814369 & $2000-12$ & $\bullet$ & $\mathbf{X}$ & --- & $\mathbf{X}$ & -- & --- \\
\hline & & 2013-18 & --- & --- & --- & --- & -- & --- \\
\hline \multirow[t]{2}{*}{ A } & 2814368 & $2000-12$ & $\bullet$ & $\bullet$ & --- & $\mathbf{X}$ & -- & $\bullet$ \\
\hline & & 2013-18 & $\mathbf{X}$ & $\bullet$ & $\bullet$ & $\bullet$ & -- & $\mathbf{x}$ \\
\hline \multirow[t]{2}{*}{ A } & 2814367 & $2000-12$ & $\bullet$ & $\mathbf{x}$ & --- & $\mathbf{x}$ & --- & $\bullet$ \\
\hline & & 2013-18 & • & - & $\bullet$ & $\bullet$ & -- & • \\
\hline \multirow[t]{2}{*}{ B } & 2814683 & $2000-12$ & - & $\bullet$ & --- & $\mathbf{X}$ & - & $\bullet$ \\
\hline & & 2013-18 & --- & --- & --- & --- & -- & --- \\
\hline \multirow[t]{2}{*}{ A } & 2814659 & $2000-12$ & $\bullet$ & $\bullet$ & --- & $\mathbf{X}$ & -- & $\bullet$ \\
\hline & & 2013-18 & --- & -- & --- & - & -- & • \\
\hline \multirow[t]{2}{*}{ A } & 2814657 & $2000-12$ & $\bullet$ & $\bullet$ & --- & $\mathbf{X}$ & - & $X$ \\
\hline & & 2013-18 & --- & --- & --- & --- & -- & --- \\
\hline \multirow[t]{2}{*}{ A } & 2814661 & $2000-12$ & • & $\mathbf{X}$ & --- & 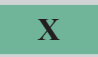 & -- & $\bullet$ \\
\hline & & 2013-18 & --- & -- & --- & --- & -- & -- \\
\hline \multirow[t]{2}{*}{ A } & 2814656 & $2000-12$ & $\bullet$ & $\bullet$ & --- & $X$ & - & • \\
\hline & & 2013-18 & -- & -- & -- & --- & -- & --- \\
\hline \multirow[t]{2}{*}{$\mathrm{C}$} & 2814790 & $2000-12$ & - & - & - & - & - & - \\
\hline & & 2013-18 & -- & --- & --- & $\mathbf{X}$ & -- & $\mathbf{X}$ \\
\hline \multirow[t]{2}{*}{ A } & 2814650 & $2000-12$ & • & $\bullet$ & --- & $\mathbf{X}$ & -- & $\bullet$ \\
\hline & & 2013-18 & --- & --- & --- & • & -- & • \\
\hline \multirow[t]{2}{*}{ A } & 2814609 & $2000-12$ & $\bullet$ & $\mathbf{X}$ & --- & $\mathbf{X}$ & - & $\bullet$ \\
\hline & & 2013-18 & - & - & - & - & - & - \\
\hline \multirow[t]{2}{*}{ A } & 2814608 & $2000-12$ & --- & $\bullet$ & --- & $\mathbf{X}$ & - & $\bullet$ \\
\hline & & 2013-18 & -- & -- & -- & --- & -- & --- \\
\hline \multirow[t]{2}{*}{ A } & 2814607 & $2000-12$ & --- & --- & --- & $\mathbf{X}$ & - & $\bullet$ \\
\hline & & 2013-18 & - & - & - & - & - & - \\
\hline \multirow[t]{2}{*}{ A } & 2814370 & $2000-12$ & $\bullet$ & X & --- & $\mathbf{X}$ & -- & --- \\
\hline & & 2013-18 & --- & --- & --- & --- & -- & --- \\
\hline
\end{tabular}


Table 23. Wells identified as providing redundant information for any contaminant of concern, Badger Army Ammunition Plant.Continued

[Well ID, unique well identifier; 2,4-DNT, 2,4-dinitrotoluene; 2,6-DNT, 2,6-dinitrolouene; TDNT, total dinitrotoluene; CTET, carbon tetrachloride; EE, ethyl ether; TCE, trichloroethene; A, well screen opening near the water table; B, well screen opening on-third from water table to bedrock; C, well screen opening two-thirds from water table to bedrock; D, well screen opening just above bedrock; E, well opening in the Eau Clair Formation; green cell with X, well not important for plume delineation; orange cell with dot, well important for plume delineation; dark gray cell with -, well not sampled; medium gray cell with --, well not assessed (no detections); light gray cell with ---, well not assessed (insufficient number of detections)]

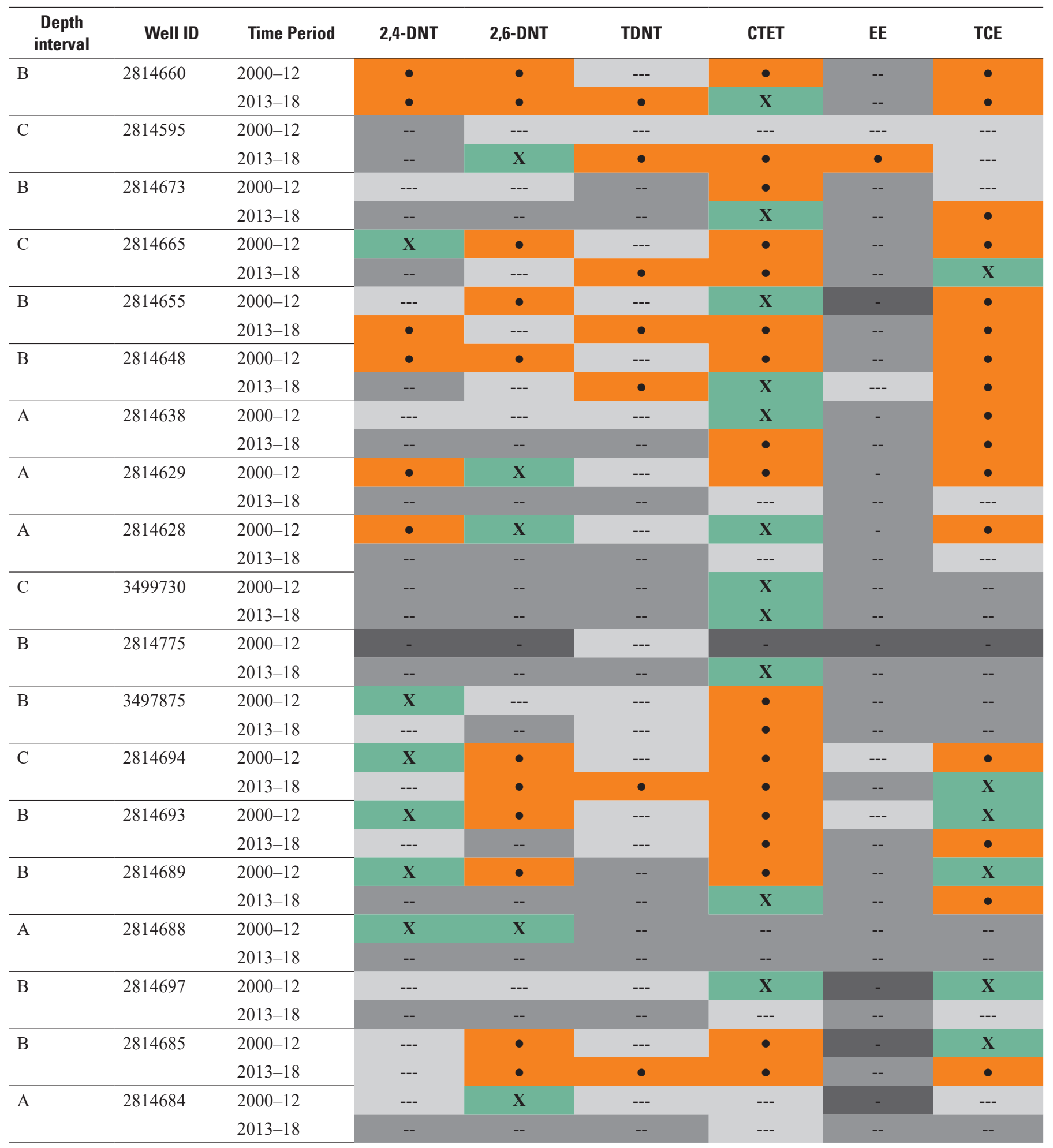


Table 23. Wells identified as providing redundant information for any contaminant of concern, Badger Army Ammunition Plant.Continued

[Well ID, unique well identifier; 2,4-DNT, 2,4-dinitrotoluene; 2,6-DNT, 2,6-dinitrolouene; TDNT, total dinitrotoluene; CTET, carbon tetrachloride; EE, ethyl ether; TCE, trichloroethene; A, well screen opening near the water table; B, well screen opening on-third from water table to bedrock; C, well screen opening two-thirds from water table to bedrock; D, well screen opening just above bedrock; E, well opening in the Eau Clair Formation; green cell with X, well not important for plume delineation; orange cell with dot, well important for plume delineation; dark gray cell with -, well not sampled; medium gray cell with --, well not assessed (no detections); light gray cell with ---, well not assessed (insufficient number of detections)]

\begin{tabular}{|c|c|c|c|c|c|c|c|c|}
\hline $\begin{array}{l}\text { Depth } \\
\text { interval }\end{array}$ & Well ID & Time Period & 2,4-DNT & 2,6-DNT & TDNT & CTET & EE & TCE \\
\hline \multirow[t]{2}{*}{$\mathrm{B}$} & 3497998 & $2000-12$ & $\mathbf{X}$ & -- & -- & $\bullet$ & -- & --- \\
\hline & & 2013-18 & --- & -- & --- & - & -- & -- \\
\hline \multirow[t]{2}{*}{ D } & 3499726 & $2000-12$ & --- & --- & --- & -- & - & -- \\
\hline & & 2013-18 & -- & -- & -- & -- & $\mathbf{x}$ & -- \\
\hline \multirow[t]{2}{*}{$\mathrm{C}$} & 3499721 & $2000-12$ & $\mathbf{X}$ & $\bullet$ & --- & $\bullet$ & -- & $\bullet$ \\
\hline & & 2013-18 & -- & - & $\bullet$ & - & -- & $\mathbf{x}$ \\
\hline \multirow[t]{2}{*}{ B } & 3499718 & $2000-12$ & --- & --- & --- & $\mathbf{X}$ & -- & $\bullet$ \\
\hline & & 2013-18 & -- & -- & -- & $\bullet$ & -- & $\bullet$ \\
\hline \multirow[t]{2}{*}{$\mathrm{C}$} & 3499717 & $2000-12$ & $\mathbf{X}$ & --- & -- & $\bullet$ & -- & -- \\
\hline & & 2013-18 & -- & -- & -- & -- & -- & --- \\
\hline \multirow[t]{2}{*}{$\mathrm{C}$} & 2814690 & $2000-12$ & $\mathbf{X}$ & $\bullet$ & -- & --- & $\bullet$ & $\bullet$ \\
\hline & & 2013-18 & -- & -- & -- & $\bullet$ & -- & --- \\
\hline \multirow[t]{2}{*}{$\mathrm{C}$} & 3499702 & $2000-12$ & $\mathbf{X}$ & $\bullet$ & -- & $\mathbf{X}$ & -- & $\bullet$ \\
\hline & & 2013-18 & -- & -- & -- & $\mathbf{x}$ & -- & -- \\
\hline \multirow[t]{2}{*}{ A } & 3499701 & $2000-12$ & -- & --- & --- & $\mathbf{X}$ & - & -- \\
\hline & & 2013-18 & -- & -- & -- & --- & -- & -- \\
\hline \multirow[t]{2}{*}{ B } & 3499720 & $2000-12$ & $\mathbf{X}$ & - & --- & $\bullet$ & -- & $\mathbf{X}$ \\
\hline & & 2013-18 & -- & --- & --- & $\mathbf{X}$ & -- & $\bullet$ \\
\hline \multirow[t]{2}{*}{ B } & 3493241 & $2000-12$ & $\mathbf{x}$ & $\bullet$ & --- & $\bullet$ & -- & -- \\
\hline & & 2013-18 & --- & -- & --- & $\bullet$ & -- & -- \\
\hline \multirow[t]{2}{*}{ E } & 3493248 & $2000-12$ & -- & -- & -- & -- & $\mathbf{x}$ & -- \\
\hline & & 2013-18 & -- & -- & -- & -- & $\bullet$ & -- \\
\hline \multirow[t]{2}{*}{$\mathrm{C}$} & 3497862 & $2000-12$ & $\mathbf{X}$ & --- & --- & --- & -- & -- \\
\hline & & 2013-18 & $\bullet$ & -- & $\mathbf{X}$ & $\bullet$ & -- & -- \\
\hline \multirow[t]{2}{*}{$\mathrm{C}$} & 3493578 & $2000-12$ & $\mathbf{x}$ & --- & -- & $\bullet$ & -- & -- \\
\hline & & 2013-18 & -- & -- & --- & $\bullet$ & -- & -- \\
\hline \multirow[t]{2}{*}{ D } & 3493576 & $2000-12$ & --- & --- & -- & $\mathbf{X}$ & -- & -- \\
\hline & & 2013-18 & -- & -- & -- & $\bullet$ & -- & -- \\
\hline \multirow[t]{2}{*}{$\mathrm{C}$} & 3493575 & $2000-12$ & $\mathbf{X}$ & $\mathbf{X}$ & --- & $\bullet$ & -- & -- \\
\hline & & 2013-18 & $\bullet$ & -- & $\bullet$ & - & -- & -- \\
\hline
\end{tabular}




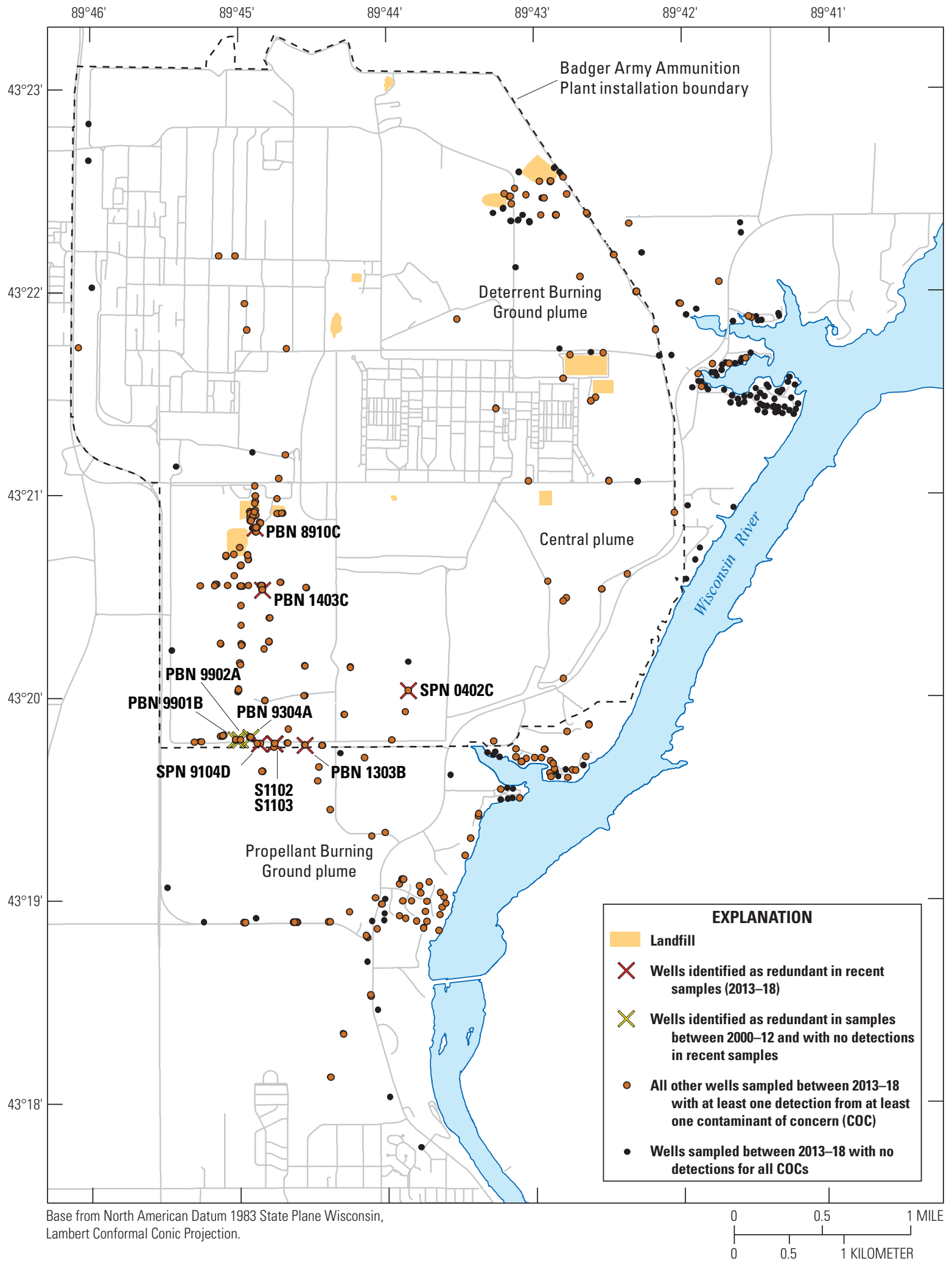

Figure 20. Map showing location of wells that were identified as redundant and suggested to be considered for removal from the monitoring network. 
Table 24. Number of wells removed from the monitoring network between the 2010-2012 and 2015-2018 sampling periods, Badger Army Ammunition Plant.

\begin{tabular}{lcc}
\hline \multicolumn{1}{c}{ Plume name } & $\begin{array}{c}\text { Number of wells sampled during 2010-12 } \\
\text { but not sampled during 2015-18 }\end{array}$ & $\begin{array}{c}\text { Number of wells removed that were } \\
\text { determined to affect plume delineation }\end{array}$ \\
\hline Propellant Burning Ground plume & 69 & 5 \\
Central plume & 18 & 0 \\
Deterrent Burning Ground plume & 17 & 5 \\
\hline
\end{tabular}

\section{Summary}

This study, conducted by the U.S. Geological Survey in cooperation with the Army Environmental Command, used a consistent data aggregation and interpolation scheme to derive the likely maximum extent of three contaminant plumes using data aggregated into four 3-year periods between 2000 and 2018 at Badger Army Ammunition Plant, Sauk County, Wisconsin. Wells were grouped according to their relative depths and assigned to a depth interval A through F. The plume extent is delineated by the isoconcentration contours equal to the Enforcement Standard for each contaminant of concern (COC) and represents the maximum concentration measured in each 3-year period. Plumes were delineated for the following COCs: total dinitrotoluene (DNT), 2,4-DNT, 2,6-DNT, trichloroethene (TCE), carbon tetrachloride (CTET), 1,1,2-trichloroethane (TCA) and ethyl ether. Delineation results are provided as maps showing the plume boundaries for each of the time periods, the sampling well network used to calculate the boundaries of each plume, and wells that were sampled in the 2010-12 period but not sampled in the 2015-18 period. The plume boundary delineations show that the spatial extent of contamination is decreasing for all COCs during the study period, except for ethyl ether in the Propellant Burning Ground plume. The apparent increase in ethyl ether plume length may be related to the necessary interpolation of concentration data across a long distance. An additional monitoring well in the D interval south of the installation boundary could result in a smaller ethyl ether plume delineation.

Some plume boundaries are not well delineated using the existing monitoring network. The qualitative analysis of uncertainty in the plume delineation (that is, the decision process to designate lines as solid or dashed) identified six primary locations where the Enforcement Standard (ES) plume boundary is not well defined at all depth intervals with the available data. The following are areas of uncertainty in the ES plume boundary in the 2015-18 period:

1. The downgradient boundary of the Propellant Burning Ground plume in the $\mathrm{C}$ and $\mathrm{D}$ intervals (TCE, CTET, 2,6-DNT, and total DNT);

2. The cross-gradient boundaries on either side of the Propellant Burning Ground source area in the A, B, and C layers (2,4-DNT, 2,6-DNT, and total DNT);
3. The cross-gradient boundary to the west of the downgradient Propellant Burning Ground plume in the B layer (CTET);

4. The cross-gradient boundary to the east of the upgradient Propellant Burning Ground plume in the A layer (CTET);

5. The upgradient plume boundary near the Deterrent Burning Ground source area (2,6-DNT and total DNT); and

6. The downgradient boundary of the Deterrent Burning Ground plume in the C layer (total DNT).

Poorly defined plume boundaries may be improved by the addition of new monitoring wells.

Statistical analyses were applied to the available concentration data for the period from 2000 to 2018. A Mann-Kendall test and power analysis were used to identify trends in concentrations in individual wells; spatial moment analysis was used to assess changes in plume mass and extent. Carbon tetrachloride (associated solely with the Propellant Burning Ground plume) showed an increasing trend in mass in the 2000-12 period, as did 2,4-DNT and 2,6-DNT in the Deterrent Burning Ground plume. Where data were sufficient to complete the analysis, no contaminants had an increasing trend in plume mass in the 2013-18 period. Trends in concentration of contaminants in individual wells varied, although in general, more wells had decreasing trends than increasing trends for most contaminant concentrations; the exceptions were 2,6-DNT in the 2013-18 period and ethyl ether in the 2004-12 period, for which more wells had an increasing trend. Individual wells with increasing trends located near source areas were of less concern because these areas are well monitored and distant from potential off-site wells that could be receptors. Individual wells with increasing trends in concentration and located near the tail of a plume indicate areas where increased monitoring may be of value to better define future plume boundaries. Such areas include the tail of the Deterrent Burning Ground plume for 2,6-DNT and total DNT in the B and C intervals and areas near the tail of the Deterrent Burning Ground plume for CTET in the B, C, D and E intervals. Similarly, wells near the tail of a plume with concentrations that continue to exceed the ES may be 
considered for additional monitoring wells. Such areas include the tail of the Deterrent Burning Ground plume for CTET in the $\mathrm{C}$ and $\mathrm{D}$ intervals, and for total DNT in the $\mathrm{C}$ interval.

An optimization analysis for the 2013-18 period identified six wells that provided information also provided by other wells. The absence of data from the six wells would not have a significant effect on the ability to delineate plume boundaries; therefore, the six wells could be considered for removal from the monitoring well network. An optimization analysis of sampling frequency did not identify any wells for which a standard sampling frequency for all COCs could be recommended.

Remedial actions directed at the Propellant Burning Ground plume coincided with a general decrease in plume mass and size, although in specific areas and depths, the plume size for specific COCs may still be increasing. Although remedial actions at the Deterrent Burning Ground plume have likely reduced the migration of contaminants into groundwater, the plume analyses did not reflect a reduction in contaminant mass in the Deterrent Burning Ground coincident with timing of the bioremediation system. The information provided by this study can be used to inform future decisions on how to best adjust the well network and sampling frequency to meet monitoring goals.

\section{References Cited}

ABB Environmental Services, Inc., 1993a, Final remedial investigation report, Badger Army Ammunition Plant, volume 1, text sections 1 through 12, prepared for U.S. Army Toxic and Hazardous Materials Agency: Accokeek, Md., ABB Environmental Services, Inc., 386 p.

ABB Environmental Services, Inc., 1993b, Final remedial investigation report, Badger Army Ammunition Plant, volume 2, tables and figures, prepared for U.S. Army Toxic and Hazardous Materials Agency: Accokeek, Md., ABB Environmental Service, Inc., 600 p.

Attig, J.W., and Clayton, L., 1990, Geology of Sauk County: Madison, Wisc., Wisconsin Geological and Natural History Survey, Information Circular 67, 1 pl.

Aziz, J., Ling, M., Rifai, H., Newell, C.J., and Gonzales, J.R., 2003, MAROS - A decision support system for optimizing monitoring plans: Ground Water, v. 41, no. 3, p. 355-367.

Badger Technical Services, 2013a, Private well sampling reduction plan Badger Army Ammunition Plant, prepared for the U.S. Department of the Army: Milwaukee, Wisc., Badger Technical Services, $82 \mathrm{p}$.

Badger Technical Services, 2013b, 2013 Groundwater narrative summary report Badger Army Ammunition Plant, prepared for the U.S. Department of the Army: Milwaukee, Wisc., Badger Technical Services, $44 \mathrm{p}$.
Badger Technical Services, 2013c, Surface waters impact investigation Badger Army Ammunition Plant, prepared for U.S. Department of the Army: Milwaukee, Wisc., Badger Technical Services, $7 \mathrm{p}$.

Badger Technical Services, 2014a, 2014 Monitoring well optimization plan, Deterrent Burning Ground and Central Plumes, Badger Army Ammunition Plant: Milwaukee, Wisc., Badger Technical Services, 17 p.

Badger Technical Services, 2014b, 2014 Groundwater narrative summary report Badger Army Ammunition Report, prepared for the U.S. Department of the Army: Milwaukee, Wisc., Badger Technical Services, $46 \mathrm{p}$.

Badger Technical Services, 2015, 2015 Groundwater narrative summary report Badger Army Ammunition Report, prepared for the U.S. Department of the Army: Milwaukee, Wisc., Badger Technical Services, $44 \mathrm{p}$.

E.C. Jordan Co, 1990a, Phase 1 remedial investigation Badger Army Ammunition Plant, draft final interim: Portland, Maine, E.C. Jordan Co., 313 p.

E.C. Jordan Co, 1990b, Phase 2 remedial investigation Badger Army Ammunition Plant, sampling design plan addendum: Portland, Maine, E.C. Jordan Co., 87 p.

Environmental Systems Research Institute (Esri), 2016a, ArcGIS desktop 10.6: Redlands, Calif., Environmental Systems Research Institute.

Environmental Systems Research Institute (Esri), 2016b, ArcScene desktop 10.6: Redlands, Calif., Environmental Systems Research Institute.

George, P.L., and Borouchaki, H., 1998, Delaunay triangulation and meshing application to finite elements: Paris, Hermes, $413 \mathrm{p}$.

Metes, M.J., Goodling, P.J., and Pajerowski, M.G., 2020, Groundwater quality and plume boundaries for select contaminants of concern at Badger Army Ammunition Plant, Wisconsin (2000-2018): U.S. Geological Survey data release, https://doi.org/10.5066/P97UKYNR.

Ridley, M.N., Johnson, V.M., and Tuckfield, R.C., 1995, Cost-effective sampling of ground water monitoring wells: Livermore, Calif., Lawrence Livermore National Laboratory (LLNL), Report UCRL-JC118909.

Sibson, R., 1981, A brief description of natural neighbor interpolation, chap. 2 of Interpolating multivariate data: New York, John Wiley \& Sons, Inc., p. 21-36.

Smith, R., 1991, Regional guidance on handling chemical concentration data near the detection limit in risk assessments, accessed March 2, 2020, at https://www.epa.gov/ risk/regional-guidance-handling-chemical-concentrationdata-near-detection-limit-risk-assessments. 
SpecPro, Inc. and Badger Technical Services, LLC, 2011, Alternative feasibility study groundwater remedial strategy Badger Army Ammunition Plant: SpecPro, Inc. and Badger Technical Services, LLC, prepared for U.S. Department of the Army, 301, 88 p.

SpecPro Professional Services, 2018, Draft supplemental remedial investigation/feasibility study, Badger Army Ammunition Plant: SpecPro, Inc. and Badger Technical Services, LLC.

Tsai, S.Y., Benioff, P.A., Chiu, S.Y., and Quinn, J.J., 1987, Draft Final: Master environmental plan for the Badger Army Ammunition Plant 2: Lemont, Ill., Energy and Environmental Systems Division, Argonne National Laboratory, $442 \mathrm{p}$.

Tsai, S.Y., Benioff, P.A., Chiu, S.Y., and Quinn, J.J., 1988, Master environmental plan for the Badger Army Ammunition Plant, volume 1, Final report: Lemont, Ill., Energy and Environmental Systems Division, Argonne National Laboratory, 227 p.

U.S. Army Corps of Engineers, 2013, Conditions of approval DGB remedy update report: U.S. Army Corps of Engineers, 8 p.

U.S. Army Toxic and Hazardous Materials Agency, 1977, Installation assessment of Badger Army Ammunition Plant report no. 111, v. 1: U.S. Army Toxic and Hazardous Materials Agency, $81 \mathrm{p}$.

U.S. Environmental Protection Agency, 1992, Methods for evaluating the attainment of cleanup standards volume 2 Ground water: U.S. Environmental Protection Agency Report EPA-230-R-92-014.
U.S. Geological Survey, 2017, 1/3rd arc-second Digital Elevation Models (DEMs), USGS National Map 3DEP downloadable data collection: U.S. Geological Survey web page, accessed December 2017 at, https:/www.sciencebase.gov/catalog/ item/4f70aa9fe4b058caae3f8de5.

Vanderford, M., Marquardt, G., and Hunter, P., 2013, MAROS 3.0-Long-term monitoring statistical and decision logic software: Columbus, Ohio, Battelle.

Warzyn Engineering Inc, 1982, Geological and soils survey and groundwater monitoring program, Badger Army Ammunition Plant: Madison, Wisc., Warzyn Engineering Inc., $104 \mathrm{p}$.

Wisconsin Department of Natural Resources, 2010, Order of the State of Wisconsin Natural Resources Board amending rules: Wisconsin Department of Natural Resources, accessed March 5, 2020, at http://docs.legis.wisconsin.gov/ $\mathrm{code} / \mathrm{misc} / \mathrm{chr} / \mathrm{lrb}$ _filed/cr_09_102_final_rule_filed with_lrb.pdf.

Wisconsin Legislative Reference Bureau, 2020, Chapter NR 140: Groundwater Quality in Wisconsin Administrative Code, accessed March 5, 2020, at https://docs.legis.wisconsin.gov/code/admin_code/nr/100/ 140.pdf\#page=4. 
For additional information, contact:

Director, MD-DE-DC Water Science Center

U.S. Geological Survey

5522 Research Park Drive, Baltimore, MD 21228

or visit our website at: https://www.usgs.gov/centers/md-de-dc-water

Publishing support provided by the U.S. Geological Survey

Science Publishing Network, West Trenton and

Reston Publishing Service Centers 


\section{$\frac{2}{4}$}

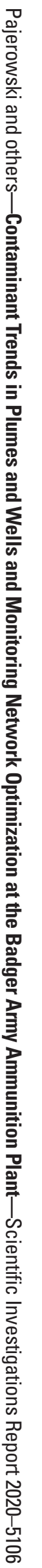

